\title{
THE POLITICAL ECONOMY OF TAKEOVER STATUTES
}

\author{
Roberta Romano*
}

I. Second Generation Takeover Statutes ......... 113

A. The Aftermath of MITE ............ 113

B. Why Is the Fair Price Approach So Popular? . 117

II. The Making of a Takeover Statute .......... 120

A. A Coalition Explanation of Takeover Legislation .......................... 120

B. The Politics of Connecticut's Second Generation Statute.................... 122

C. Predicting the Adoption of a Second Generation Takeover Statute ................... 142

III. The Rationality of Investor Support of Fair Price

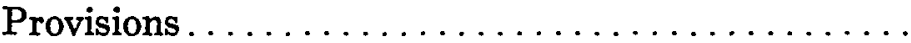

A. A Decision Tree Analysis of the Decision to Tender ....................... 148

B. When Might Investors Decide to Support a Fair Price Provision?................... 170

IV. Conclusion .................... 187

Appendix ..................... 190

7 me most lively debate in corporate law today concerns takeovers. There are two important questions. The first is whether takeovers, or efforts to prevent them, are in the interest of shareholders. This has implications for the second issue-whether, and to what extent, the states and the national government should reg-

* Professor, Yale Law School. I would like to tbank Rick Antle, Lucian Bebchuk, Doug Branson, Steve Brown, Joel Demski, Philip Dybvig, Henry Hansmann, Jon Ingersoll, Al Klevorick, Lewis Kornhauser, Reinier Kraakman, Saul Levmore, Steve Maser, Stepban Morgenthaler, Steve Ross, Jeff Strnad, Michael Trebilcock, Oliver Williamson, and participants in workshops at the Center for Study of Public Choice, George Mason University, and the Harvard, Toronto, Virginia, and Yale law schools for helpful comments and suggestions. I would also like to thank the legislators, attorneys, and lobbyists who were kind enough to answer my questions concerning the making of Connecticut's takeover laws. All errors are, of course, my own. 
ulate offers and defenses. This article seeks to shed light on both of these questions by examining the actions of states and firms in the takeover game.

The national government's preeminent, albeit controversial, role in takeovers was legislated by Congress with the Williams Act, ${ }^{1}$ which establishes the ground rules for tender offers. State legislatures, however, have often intervened in the takeover process, stretching the fundamental requirements of the Williams Act, for the most part at the expense of bidders. Although the Supreme Court sought to stem the states' efforts at broad regulation when it held in Edgar v. MITE Corp. ${ }^{2}$ that Illinois' takeover statute burdened interstate commerce, states, within months of the decision, fashioned new takeover legislation. To add to the statutory and jurisdictional complexity, when bidders and target firms have engaged in extensive legal maneuvering, federal and state courts, more often than not, have been passive bystanders to the battles. ${ }^{3}$ The result has been unsettled case law and a barrage of complaints by commentators, practitioners, and legislators. Not surprisingly, there has been a flurry of proposals for an even greater federal regulatory role.* Although the SEC has expressed disagreement with several state court decisions and has begun the process of overturning them by regulation, it has forcefully opposed suggestions to displace fully the authority of the states. ${ }^{5}$

This article takes two distinct approaches in analyzing the takeover debate. After describing the three archetypal second generation state takeover statutes, I examine in depth the politics behind the enactment of such a statute in Connecticut. As I reside there,

${ }^{1}$ Securities Exchange Act of 1934, $\S \S 13(d)-(e), 14(d)-(f), 15$ U.S.C. $\S \S 78 l(\mathrm{i}), 78 \mathrm{~m}(\mathrm{~d})-(\mathrm{e})$, $78 \mathrm{n}(\mathrm{d})$-(f) (1982).

2457 U.S. 624, 643-46 (1982).

3 See, e.g., Treadway Cos. v. Care Corp., 638 F.2d 357 (2d Cir. 1980).

4 Even the Federal Reserve Board has gotten into the action. The Board proposed to apply its margin requirements to takeover bids financed by junk bonds, although the Reagan appointees dissented. Changing the Rules: Attacking Junk Bonds, Fed Becomes a Player in the Takeover Game, Wall St. J., Dec. 9, 1985, at 1, col. 6.

- See Amendments to Tender Offer Rules: All-Holders and Best-Price, Exchange Act Release No. 23,241 51 Fed. Reg. 25,873 (July 17, 1986) ("All Holders" rule, overruling Unocal Corp. v. Mesa Petroleum Co., 493 A.2d 946 (Del. 1985)); Hearings Before the Subcomm. on Telecommunications, Consumer Protection, and Finance of the House Comm. on Energy and Commerce, 98th Cong., 2d Sess. 10 (March 28, 1984) (Statement of John Shad, Chairman, SEC), reprinted in [1983-84 Transfer Binder] Fed. Sec. L. Rep. (CCH) II 83,511, 86,678; The Annual Report of the Council of Economic Advisors 215 (1985). 
it had the advantage of geographical convenience, and the experience of other states appears to be similar. I also draw some conclusions from the legislative process in Connecticut as to why Delaware, the most favored incorporation state, may be better situated to evaluate more soberly, if not to resist, the enactment of a takeover law. My hope is that a micro explanation of the politics that produce such corporation laws will generate insights for policymakers concerning the appropriateness of state regulation of takeovers.

The second approach taken by this article originates in the puzzle of why there is a need for legislation in the first place. Because takeover statutes codify defensive tactics that firms adopt by charter amendment, self-help would appear to be an equally feasible course of action. To investigate this question, I map out a shareholder's decision concerning how to respond to a tender offer in the presence of different antitakeover rules. I then suggest that the usual presumption that a firm's shareholders have identical interests is inappropriate in this context due to differences in information costs among shareholders. I accordingly offer an explanation keyed to the firm's ownership composition for when a firm will adopt shark repellent charter amendments. One implication is that a statute, under specified conditions, can enable a firm's managers to obtain protection comparable to a charter provision that would not have been adopted by a shareholder vote. The statutes are therefore troublesome, for they can produce results that are inconsistent with the core goal of corporation law-the maximization of equity share prices. A further implication of the analysis is an explanation for why the most popular shark repellent amendment and second generation takeover statute is a fair price provision.

\section{Second Generation Takeover Statutes}

\section{A. The Aftermath of Edgar v. MITE Corp.}

The popularity of takeover regulation is impressive. First generation takeover statutes were enacted across the states at a quicker pace than all other innovations in corporation codes in recent history. ${ }^{6}$ In 1982 , the year $M I T E$ was decided, thirty-seven states had takeover statutes. Moreover, the MITE decision has done little to

\footnotetext{
- See Romano, Law as a Product: Some Pieces of the Incorporation Puzzle, $1 \mathrm{~J} . \mathrm{Law}$, Econ. \& Organization 225, 234 (figure 1) (1985).
} 
abate interest in the regulation of takeovers. Within four years of the decision, new takeover laws have been adopted in twenty-one states. Not surprisingly, a state's adoption of a second generation statute is strongly correlated with its having had a first generation statute. $^{7}$

These second generation takeover laws have been shaped to circumvent the problems of the Illinois statute struck down in MITE. That statute had both substantive and jurisdictional flaws. It created a waiting period before an offer could be initiated, a restriction that went well beyond the requirements of the Williams Act, and enabled Illinois to further delay a bid through an administrative hearing on the fairness of the offer and the adequacy of disclosure. $^{8}$ In addition, the statute had a broad jurisdictional reach, such that a bid subject to the Illinois law could also be subject to regulation by numerous other states. ${ }^{9}$

The second generation statutes share characteristics that distinguish them from the Illinois statute. ${ }^{10}$ The jurisdictional nexus has

? The Spearman rank correlation for adoption of both a first and second generation statute in which the states are ranked by the order of the date of enactment of the statutes was 0.4313 , which is significant at the .005 level for a one-tailed test $(t=3.31)$.

8 Illinois subjected takeovers to a state regnlatory process that delayed the commencement of a bid by requiring a 20-day registration period during which the state could initiate a hearing on the bid's fairness and the adequacy of the bidder's disclosure. See Illinois Business Takeover Act $\S$ 4(E), 7(E), 1978 Ill. Laws 1581, 1586-87 (repealed). No shares could be acquired before the registration period expired or the hearing had terminated. The Williams Act has no waiting period, but it does require bidders to allow shareholders who tender their shares to withdraw them during an initial period, 15 U.S.C. $\S 78 \mathrm{n}(\mathrm{d})(5)(1982)$, which, at the time of the MITE decision, was the first seven days of the offer. This has the effect of delaying the finalization of an offer for the duration of the withdrawal period.

- The statute covered a target firm if $10 \%$ of the shareholders were located in Illinois or if two of the following three conditions were satisfied: the target's principal executive office was in Illinois; it was organized under Illinois law; or $10 \%$ of its stated capital and paid-in surplus were represented within the state. Illinois Business Takeover Act § 2.10, 1978 Ill. Laws 1581, 1583-84 (repealed).

10 A number of states chose to modify their takeover statutes after MITE by narrowing the jurisdictional base and by tinkering with or eliminating the registration and hearing requirements for publicly traded corporations. Tighter jurisdictional requirements include application to firms with a specified number of resident shareholders and assets in the state. See, e.g., Oklahoma Take-over Disclosure Act of 1985, § 2, Okla. Stat. Ann. tit. 71, § 452 (West Supp. 1987) (20\% Oklahoma shareholders and substantial assets in state). In some states, hearing and preregistration requirements are retained only for firms that are not covered by federal law. See, e.g., Conn. Gen. Stat. Ann. $\S \S 36-456$ to -468 (West 1981 \& Supp. 1986); Wis. Stat. Ann. $\S \S 552.01-.25$ (West Supp. 1986). In other states, administrative review of a bid must be completed before the expiration of the Williams Act's minimum offering and withdrawal rights periods. See, e.g., Oklahoma Take-over Disclosure Act of 
been tightened: conforming with the traditional choice of law rule in corporate law, the statutes apply only to domestically-incorporated firms. In addition, the substantive features are less burdensome on interstate commerce. Where a statute requires approval of a transaction, it is only the firm's shareholders, not a state agency, whose decision determines the outcome, and, in contrast with the earlier statutes, firms may opt out of the new regulatory regimes.

But unlike the first generation takeover statutes, which were all cut from the same cloth, the second generation statutes have three distinct patterns. They are a striking example of extensive experimentation by states in legal innovation. This variety may, however, be induced by uncertainty regarding the scope of the constitutional constraint imposed by $M I T E$ rather than by disagreement concerning the most effective regulation. For although MITE held the most potent takeover statute unconstitutional, it did not hold that the Williams Act preempted state regulation. The decision may reasonably be understood as expressing greater concern over the Illinois statute's broad jurisdictional reach than its substantive content.

The initial second generation takeover statute was Ohio's control share acquisition law, ${ }^{11}$ enacted only a few months after the MITE decision. Under this provision, a majority of disinterested shareholders must approve the acquisition of control by any person. ${ }^{12} \mathrm{~A}$ control share acquisition is defined as either the acquisition of at least twenty percent of the firm's stock or an acquisition that increases a person's holdings such that the shareholder moves from one statutory range of voting power to another. ${ }^{13}$ Firms may exempt themselves from the control share acquisition statute by a

1985, § 3(D)-(E), Okla. Stat. Ann. tit. 71, § 453 (West Supp. 1987). These changes probably bring the statutes within constitutional requirements, but they also strip them of their most potent weapon, their effectiveness at delaying a bid. Because the success of a bid is a function of the offer price, which must be pitched to market conditions, the timing of the bid is critical. Even a brief delay can misprice an offer and thereby increase the likelihood of a bid's defeat. Moreover, delay increases the probability that a competing bidder with lower acquisition costs will enter either because it can free ride on information concerning the target's value revealed by the original bid or because it is aided by target management seeking a friendlier suitor.

11 Ohio Rev. Code Ann. $\S 1701.83 .1$ (Anderson 1985).

12 All of the statutes include entities in the definition of a person. See, e.g., id. $\S 1701.01$ (G).

Is Id. $\S 1701.01(\mathrm{Z})$. The ranges of voting power are one-fifth to less than one-third; onethird to less than a majority; a majority or more. Id. 
corporate charter or bylaw amendment. A sympathetic view of the statute's approval requirement is that by partially conforming stock purchases to the existing requirements for asset purchases or mergers, it moves the corporation code in the direction of treating different modes of acquisitions uniformly.

The second type of regulation to be adopted was Maryland's fair price provision. ${ }^{14}$ Directed against front-end loaded, two-tier acquisitions, this statute codified one of the most common shark repellent charter amendments. When a firm engages in a business combination with a person owning ten percent of the firm's stock, a supermajority vote of the shareholders (eighty percent of the total outstanding stock plus two-thirds of the disinterested shares) is required for approval unless certain conditions are met. ${ }^{15}$ The exempting provisions require either the approval of a disinterested board of directors, which in essence is the board as constituted prior to the interested shareholder's acquisition of ten percent, or the payment of a fair price, which is, for the most part, the higher of any price the interested party paid to obtain its shares or the market price at the time of the combination. Firms can opt out of the fair price statute by board resolution within two months of the statute's effective date, or at any time by a supermajority shareholder vote. Like the Ohio control share acquisition statute, one effect of this provision is to blur the statutory distinctions between takeover bids and mergers or asset sales by subjecting more corporate acquisitions to board or shareholder approval. Yet unlike the control share acquisition statute, Maryland's fair price approach strengthens incumbent management's bargaining position because, to the extent that obtaining board approval is cheaper than meeting either the fair price or supermajority vote requirements, bidders' incentives to make side payments to management are increased.

The third pattern is the redemption rights statute enacted by Pennsylvania approximately a year after Ohio's control share acquisition statute was passed.16 Upon a person's acquisition of

14 Md. Corps. \& Ass'ns Code Ann. §§ 3-601 to -603 (1985 \& Supp. 1986).

15 Business combinations are broadly defined to include mergers, consolidations, share exchanges, asset sales, leases or transfers, stock issuances equal to five percent of the outstanding stock market value, liquidations, dissolutions, reclassifications of securities, and recapitalizations. Id. at § 3-601(e).

${ }_{16} \mathrm{~Pa}$. Stat. Ann. tit. 15, § 1910 (Purdon Supp. 1986). 
thirty percent of a firm's stock, all of the remaining shareholders are entitled to receive, on demand, from the acquirer an amount in cash equal to the fair value of the stock, including the proportional increment payable as a control premium. A corporation can opt out of the redemption rights requirement by a board resolution adopted within ninety days of the statute's effective date, or at any time by charter amendment. The effect of the statute is to convert partial offers into any-or-all offers. It can also be characterized as a move to more uniform treatment of acquisitions, in that it extends appraisal rights, which are generally accorded in mergers and asset sales, to sales of stock.

\section{B. Why Is the Fair Price Approach So Popular?}

Of the three paradigmatic second generation takeover statutes, the Maryland fair price provision has been the most popular with other states. Within three years after the enactment of the Maryland statute, thirteen more states added a fair price provision to their corporation codes, ${ }^{17}$ while only five copied the Ohio control share acquisition legislation. ${ }^{18}$ The figures double count Indiana

17 The states with fair price statutes are: Connecticut, Conn. Gen. Stat. Ann. \$\$ 33-374a to -374c (West Supp. 1986); Georgia, Ga. Code Ann. \$§ 14-2-232 to -234 (Supp. 1986); Illinois, Ill. Ann. Stat. ch. 32, para. 7.85 (Smith-Hurd Supp. 1986); Indiana, Ind. Code Ann. § 23-1-43 (Burns Supp. 1986); Kentucky, Ky. Rev. Stat. Ann. §§ 271A.396-.398 (Baldwin 1986); Louisiana, La. Rev. Stat. Ann. $\S \S 12: 132-134$ (West Supp. 1986); Maryland, Md. Corps. \& Ass'ns Code Ann. $\$ \S 3-601$ to -603 (1985 and Supp. 1986); Michigan, Mich. Comp. Laws. Ann. §§ 450.1776-.1784 (West Supp. 1986); Mississippi, Miss. Code Ann. §§ 79-25-1 to -7 (Supp. 1986); New Jersey, 1986 N.J. Sess. Law Serv. ch. 74 (West); New York, N.Y. Bus. Corp. Law § 912 (McKinney 1986); Virginia, Va. Code Ann. \$§ 13.1-725 to -728 (1985); Washington, Wash. Rev. Code § 23A.08.425 (Supp. 1986); Wisconsin, Wis. Stat. Ann. \$ 180.725 (West Supp. 1987). The most recent variations of this type of takeover statute, passed by Indiana, New York, and New Jersey, refine the Maryland approach to impose greater restrictions on bids. They prohibit business combinations with interested shareholders for five years after the acquisition of the interest, with only few exceptions, and the approval of a majority of disinterested shares is required for combinations after the fiveyear waiting period.

18 The states with control share acquisition statutes are: Hawaii, Haw. Rev Stat. $\$ 416-$ 171 to -172 (Supp. 1986); Indiana, Ind. Code Ann. $\$$ 23-1-42 (Burns Supp. 1986); Minnesota, Minn. Stat. Ann. § 302A.671 (West 1985 \& Supp. 1987) (amended 1985); Missouri, Mo. Ann. Stat. $\$ 351.407$ (Vernon Supp. 1986); Ohio, Ohio Rev. Code Ann. $\$ 1701.831$ (Anderson 1985); Wisconsin, Wis. Stat. Ann. $\$ 180.25$ (9) (West Supp. 1986). Again, the more recent enactments, such as the Indiana statute, refine the original statute. The acquisition of control shares itself is not subject to disinterested shareholders' approval, but those shares' voting rights must be approved. 
and Wisconsin, which enacted both fair price and control share acquisition statutes. The least popular approach, followed by only two states, is Pennsylvania's redemption rights statute. ${ }^{19}$

The popularity of the fair price statute is a function of several factors. Of the three types of takeover laws, a fair price statute is the least restrictive of takeovers because it applies only to the second stage of a two-tier offer. Hence, the object of regulation is the most distinct from that of the Illinois statute invalidated in MITE. Part of the impetus for adoption of this approach in other states, such as Connecticut, appears to be the Maryland Attorney General's issuance of an opinion that the statute is constitutional. ${ }^{20}$ Concern over the constitutionality of other approaches is wellfounded. Control share acquisition statutes have uniformly been held unconstitutional. ${ }^{21}$ These decisions have had repercussions: the invalidation of Minnesota's control share acquisition provision, ${ }^{22}$ for example, prompted Wisconsin to adopt a new statute. ${ }^{23}$ It is therefore reasonable for a cautious or cost-conserving legislature to choose a fair price statute over the other two possibilities.

In addition, a fair price statute is easier to justify than the other provisions as being in the interest of shareholders. A longstanding contention advanced by distinguished corporate law scholars is that two-tier offers coerce shareholders to tender at a price lower

10 The states with redemption rights statutes are: Maine, Me. Rev. Stat. Ann. tit. 13-A, § 910 (Supp. 1986); Pennsylvania, Pa. Stat. Ann. tit. 15, § 1910 (Purdon Supp. 1986); Utah, Utah Code Ann. § 16-10-76.5 (Supp. 1986).

20 The decision ruling Maryland's first generation takeover statute unconstitutional, which arose from the highly publicized takeover battle between Bendix and Martin Marietta, Bendix Corp. v. Martin Marietta Corp., 547 F. Supp. 522 (D. Md. 1982), was in the minds of local corporations and legislators when Maryland's fair price statute was enacted, see Dept. of Legislative Reference, Staff Report to the General Assembly of Maryland on Corporations and Associations: Consideration of the Problem of Special Voting Requirements in Consolidations, Mergers, Takeovers, and Transfers of Assets, Extraordinary Sess., June 1983, at 9, and the Attorney General's opinion on the proposed statute's constitutionality was requested, id. at 65-72.

${ }^{21}$ See, e.g., Fleet Aerospace Corp. v. Holderman, 796 F.2d 135 (6th Cir. 1986) (Ohio); Dynamics Corp. of Am. v. CTS Corp., 794 F.2d 250 (7th Cir. 1986), cert. granted, 55 U.S.L.W. 3198 (U.S. Oct. 7, 1986) (Indiana); Terry v. Yamashita, 643 F. Supp. 161 (D. Haw. 1986) (Hawaii).

23 APL Ltd. Partnership v. Van Dusen Air, 622 F. Supp. 1216 (D. Minn 1985).

2s See Wis. Stat. Ann. § 180.25(9) (West Supp. 1986). The statute, similar to Indiana's control share acquisition statute, reduces the voting power of anyone holding $20 \%$ or more of a firm's stock to $10 \%$, unless a majority of the shareholders vote to restore the shares' voting rights. 
than that which they believe their shares to be worth. ${ }^{24}$ Commentators maintain that shareholders are pressured to tender in the first step because they fear they will receive an even lower price for their shares in the second step, a merger in which the bidder, now the controlling shareholder, is able to set the terms. To eliminate this whipsaw effect, commentators have supported a guarantee of the same price in both steps, ${ }^{25}$ one of the alternative conditions for a business combination in the Maryland statute. Recognition of a need for equal treatment among shareholders makes a fair price statute appealing; the concern for preventing allegedly coercive tenders is ammunition for refuting the contention that the legislation is principally a device to entrench poorly performing managers by discouraging takeovers.

The most compelling explanation for the popularity of the fair price statute, however, is that it provides more firms with what they want. The pattern of voluntary adoptions of shark repellent amendments is a reasonable proxy for firm preferences. I examined the charters of two sets of New York Stock Exchange (NYSE) firms-the 293 firms incorporated in the fourteen states that had enacted second generation statutes at the time the research for this article was initiated, and a random sample of 200 firms incorporated in the remaining thirty-six states. Of the three statutory variations, the fair price provision was adopted by more corporations: 109 (twenty-two percent) had a fair price provision in their charter. By contrast, only nine had a redemption rights guarantee and two a control share acquisition provision, and both of these two were adopted to conform the firms' charters to the Ohio statute. ${ }^{26}$ Perhaps even more telling evidence of firms' preference for a fair price provision is that eight of the fourteen Pennsylvania corporations with fair price provisions adopted them after the enactment of Pennsylvania's redemption rights statute, whereas no firms in

26 See, e.g., Brudney \& Chirelstein, Fair Shares in Corporate Mergers and Takeovers, 88 Harv. L. Rev. 297, 336-37 (1974). But see Grossman \& Hart, Takeover Bids, the Free-Rider Problem, and the Theory of the Corporation, 11 Bell J. Econ. 42 (1980).

25 See Brudney \& Chirelstein, supra note 24, at 337.

26 A recent study by the SEC corroborates the point. The study found that fair price provisions predominate over all other types of shark repellent amendments. See Office of the Chief Economist of the SEC, Shark Repellents and Stock Prices: The Effects of Antitakeover Amendments Since 1980, at 4 (1985) [hereinafter SEC, Shark Repellent Amendment Study] (75\% of 649 shark repellent amendments were fair price provisions). 
states with a fair price statute added a redemption rights provision to their charters. Moreover, nine firms opted out of Pennsylvania's redemption rights statute and two opted out of Ohio's control share acquisition statute, but I did not find any firms opting out of a fair price regime. In short, a state legislature seeking to enact a takeover statute that most closely tracks its corporate constituents' desires would choose Maryland's fair price approach.

The frequency with which firms adopt fair price provisions suggests a transaction cost explanation for the rapid diffusion of the fair price statute. If corporations desire a specific provision in their charter, it reduces their costs if corporation laws codify the provision, because the firm's participants will not have to incur the expense of bargaining over inclusion of the clause. This is an explanation that views corporation codes as standard form contracts, which firms can tailor to better fit their affairs. ${ }^{27}$

But a transaction cost explanation for second generation statutes is not especially persuasive. While fair price provisions are by far the most prevalent shark repellent amendment, less than onequarter of the firms in my sample had such provisions. If the absence of a fair price provision signals that the owners believe that such a provision is not in their interest, a statutory presumption of a fair price rule imposes costs on these firms because they will have to take affirmative steps to opt out of the rule. Yet a certificate's silence may be ambiguous. Some firms may desire fair price protection but be unwilling to act openly and thereby attract the attention of bidders. Hence, a transaction cost explanation cannot be evaluated in the abstract. The discussion that follows seeks to provide information on the politics behind the passage of these laws and on firms' self-help decisions-information that is needed to reach an informed judgment on the merits of the new statutes.

\section{The Making of a Takeover Statute}

\section{A. A Coalition Explanation of Takeover Legislation}

I undertook the research for this article in order to explore the conjecture that takeover statutes are supported by a broad coalition of interest groups that include, in addition to target corpora-

${ }^{27}$ For a cogent statement of this explanation of corporation law, see R. Posner, Economic Analysis of Law 369-72 (3d ed. 1986). 
tions and their management, organized labor and community groups who have no interest in the everyday making of corporation codes. I derived this scenario from reports in the business press that intimated that such a coalition was possible.

For instance, when the Gulf Corporation was acquired by the Standard Oil Company of California, press accounts emphasized the fear in Pittsburgh that the local economy would be adversely affected if Gulf's corporate headquarters were transferred after the control change. ${ }^{28}$ This fear arose because three percent of the donations to the local United Way $(\$ 700,000)$ came from Gulf and its employees; a local messenger service stood to lose ten percent of its local billings ( $\$ 150,000)$; and Allegheny County faced the loss of $\$ 2$ million in personal and corporate property taxes. ${ }^{28}$ Further, Gulf contributed $\$ 2$ million to an estimated fifty Pittsburgh charitable institutions in the year prior to its acquisition, and intangible losses could be projected because some of the city's most active civic leaders were Gulf executives. ${ }^{30} \mathrm{I}$ thought that the Pittsburgh story would be representative and that unions and community groups, because of their concern over the deleterious impact of a control transfer on the local social and economic equilibrium, would easily be mobilized to support laws regulating takeovers. My conjecture was that such concerns would be most prevalent in states with higher unemployment or slower economic growth, like Pennsylvania, than in more prosperous regions, where the relocation of one firm would have no perceptible effect on a vibrant local economy.

The significance of a coalition explanation of takeover regulation for corporate law is its connection to the central debate over who benefits-managers or shareholders-from the competition among

28 See Gulf's Departing Pittsburgh Would Deal a Harsh Blow to City's Economy and Pride, Wall St. J., Mar. 9, 1984, at 33, col. 3 [hereinafter Gulf's Departing]; see also What Merger Mania Did to Syracuse, Fortune, Feb. 3, 1986, at 94 [hereinafter Syracuse Merger Mania] (discussing similar concerns in Syracuse and finding tbat takeover did not cause the problem feared).

30 Gulf's Departing, supra note 28. For analogous information on Syracuse, see Syracuse Merger Mania, supra note 28, at 94-98.

so Gulf executives served on the boards of local hospitals, schools, churches, and civic organizations, as well as the boards of local businesses. Gulf's Departing, supra note 28 . See also Merger Fever Affecting Corporate Philanthropy, N.Y. Times, Jan. 21, 1986, at A19, col. 1 (describing nonprofit organizations' perceptions that mergers change firms' philanthropic patterns). 
states for the corporate charter business. The coalition explanation could resolve, at least indirectly, a puzzle identified in an earlier article of mine on state competition: one of the features of corporation codes that attracts firms is the facilitation of antitakeover defensive tactics. ${ }^{31}$ This finding creates serious difficulties for the position espoused by several scholars that state competition produces corporation codes that maximize shareholder welfare but that management efforts to thwart tender offers are at odds with shareholders' interests. The appearance of an unusually broad coalition supporting a corporate law provision would provide indirect evidence that the law did not serve the interest of shareholders in a context where shareholders' and managers' interests may diverge. The thesis is that managers are better positioned to secure the enactment of legislation that shareholders do not desire when managers can align themselves with interest groups outside the shareholder-manager nexus. This is an intuitively appealing explanation, because even if the overwhelming majority of corporation code provisions are beneficial to shareholders, some might not be so. Namely, state takeover laws could be aberrational in their politics.

\section{B. The Politics of Connecticut's Second Generation Statute}

In 1984, Connecticut adopted a second generation takeover statute that was modeled after the Maryland fair price legislation. The statute requires business combinations with interested shareholders (ten percent owners) to be approved by supermajority vote (eiglity percent plus two-thirds disinterested shares) unless either the transaction is approved by a disinterested board or the terms of the combination equal essentially the higher of the highest price the interested party paid for its shares or the current market price. ${ }^{32}$ Although key features of the enactment of the statute differed from the adoption of other corporation law provisions, a simple version of the coalition explanation is an incorrect characterization of the political dynamics. The spur behind the passage of the Connecticut statute was not a broad-based political coalition. Rather, the bill was promoted by a corporation incorporated in

\footnotetext{
32 See Romano, supra note 6, at 249-50.

${ }^{32}$ Conn. Gen. Stat. Ann. §§ 33-374a to -374c (West Supp. 1986).
} 
Connecticut, the Aetna Life and Casualty Insurance Company (Aetna), which enlisted the support of the most important business association in the state, the Connecticut Business and Industry Association (CBIA). ${ }^{33}$

\section{The Legislation's Proponents}

The political influence that a major corporation like Aetna could have upon Connecticut's legislature is no surprise. Aetna is one of eighteen NYSE corporations incorporated in Connecticut. Two years before the enactment of the second generation takeover statute, it was second among the top one hundred publicly-traded Connecticut companies ranked by sales, with assets valued at approximately $\$ 44$ billion, sales of approximately $\$ 14$ billion, and profits of approximately $\$ 427$ million. $^{34}$ Although these facts of themselves do not demonstrate that Aetna has political clout, they suggest that its welfare would not go unnoticed by conscientious state legislators. Moreover, the company is widely perceived to be a "first class local corporate citizen." veyed to me in conversations with individuals involved in the making of Connecticut's second generation takeover statute is that, because of the conflux of these tangible and intangible assets, Aetna has considerable influence in state politics.

Similarly, as the largest organization representing business firms in the state, the CBIA would be expected to be influential in state politics. It has a membership of over 6,000 Connecticut businesses,

\footnotetext{
ss Although Aetna did not cooperate in uny study, I believe that I have sufficient information to provide an accurate account of what occurred in Connecticut. When I started the research for this article, I was told that Aetna had been involved in the legislation. After several frustrating months of unsuccessful attempts to meet witb members of Aetna's legal staff who had worked on the bill, I concluded that they were not anxious to discuss the matter with me, even though I assured them that their firm would not be identified in my study. I then proceeded to collect information from other sources-interviews and telephone conversations with legislators, lobbyists, and lawyers. After having obtained a good picture of what had occurred, I contacted the individual in charge of Aetna's legal department. Unlike his staff, he returned my call promptly, but he did not provide any information beyond what I had already learned. He also refused to make available drafts of the bill that was eventually enacted. I therefore decided to identify Aetna, since the firm neither facilitated my research nor provided me with any confidential information.

st The Top 100, Bus. Times, May 1983, at 4. For later years, the top 100 ranking has been restricted to manufacturing firms, which excludes financial services firms like Aetna. See The Top 100, Bus. Times, May 1984, at 4.

ss The Game of Clean Money, New England Monthly, Feb. 1986, at 56.
} 
which includes both manufacturing and financial firms, and is essentially a state chamber of commerce. Although approximately eighty percent of the members are small firms with less than one hundred employees, the major corporations in the state, including Aetna, are represented on the managing board.

Like most trade associations, the CBIA engages in extensive lobbying. It is in fact the largest lobbying organization in Connecticut. It has several registered lobbyists and is the perennial leader in legislative lobbying expenditures. For example, in 1984, the year the second generation takeover statute was enacted, the CBIA spent slightly less than $\$ 250,000$ on legislative lobbying. This dollar amount might seem small, but in relative terms it is substantial. The organization with the second highest level of expenditures, a utility company, spent only slightly more than $\$ 70,000 .^{36}$ Given its ability to allocate considerable funds for lobbying, the CBIA is a force to be reckoned with in Connecticut politics.

Before actively promoting Aetna's takeover bill with legislators, the CBIA leadership consulted some of its other members concerning the merits of the draft legislation. There were no objections. There is a straightforward explanation for this consensus: of the largest Connecticut corporations that are most comparable to Aetna and more likely to be affected by the statute-the other seventeen firms listed on the NYSE-most would be untouched by the proposal. Five of the firms already had similar fair price provisions in their charters, and seven of the firms had a ten percent shareholder and would therefore be exempt from the statute's coverage. ${ }^{37}$ Moreover, only a few Connecticut corporations are active acquirers that might have a different perspective than target firms

36 All figures are from Connecticut State Ethics Comm'n, Registered Lobbyists and their Expenditures and Receipts as Reported to Connecticut State Ethics Commission for Calendar Year 1984 (1985). The CBIA expenditure is approximately $31 \%$ of the total spent by the top 10 lobbying organizations in the state.

${ }^{37}$ A $10 \%$ shareholder exemption had been included in the Maryland statute that served as the model for Connecticut at the urging of local corporations that otherwise opposed the legislation. See infra note 72. In the 1985 legislative session Connecticut eliminated the $10 \%$ shareholder exemption and all publicly traded Connecticut corporations were brought under the fair price provision. 1985 Conn. Acts $85-283$ (Reg. Sess.) (codified at Conn. Gen. Stat. Ann. § 33-374c (West Supp. 1986)). This bill was tinnely introduced and unanimously approved. No one testified at tle scheduled liearing, although one attorney submitted a written statement in favor of the proposal. The rumor is that a corporation with a block of stock in unfriendly hands wanted to be covered by tlie statute to protect itself against any effort of the owner of the block to acquire the firm. 
on takeover legislation. The absence of such a constituency in the state surely helps to explain the general support for, or indifference to, the statute within the business community.

But even if there had been more firms in Connecticut with an aggressive merger and acquisition policy, it is not obvious that they would have opposed Aetna's bill. For instance, one of the more prominent acquisition-oriented firms headquartered in Connecticut, United Technologies, has a fair price provision in its charter. ${ }^{38}$ In addition, even a firm that is an aggressive acquirer and not concerned about becoming a target itself might not perceive a fair price statute to be a problem. The firm may engage primarily in friendly or one-tier acquisitions, or have little interest in acquiring Connecticut corporations. In any event, there was no business constitutency that was troubled by the proposed takeover legislation.

\section{The Procedural Setting}

One would surely expect the active involvement of major corporations and business organizations such as Aetna and the CBIA in any important change in a state's corporation code. The politics of Connecticut's fair price provision fits that intuition. Still, the enactment of the takeover provision had a peculiar history compared with the adoption of most changes in Connecticut's corporation code. It was introduced late in the 1984 legislative session, passed by both houses, and signed by the governor in approximately two months. The irregularity is not the ease with which the legislation was passed but the absence of process that marked its legislative journey.

Connecticut requires all bills for consideration in a legislative session to be introduced by a specified date. This requirement can be circumvented by introducing the matter as an amendment to a bill that was timely filed. Having missed or waited for the session's deadline, the proponents of Connecticut's takeover statute had their proposal attached as an amendment to a minor bill that concerned the reservation of corporate names. ${ }^{39}$ That bill had been

36 United Technologies, 1983 Proxy Statement 14-19. United Technologies is headquartered in Connecticut, but its statutory domicile is Delaware.

30 The use of the amendment procedure to avoid the filing deadline is not that uncommon in Connecticut. At the Connecticut Lobbying Conference, which was held in Hartford on October 8, 1985, legislators, staff personnel, and lobbyists recounted a number of in- 
sponsored by the Secretary of State's office and was supported by the executive committee of the corporate law section of the state bar association. The Secretary of State's office was not involved in the drafting of the takeover provision and was not even aware of the addition to its bill until after the amended bill was scheduled for a vote on the senate floor. The bar committee was similarly not apprised of the amendment until the eleventh hour.

A procedural advantage of the amendment process is that public discussion of a bill may be bypassed. Connecticut mandates a pubhic hearing for all bills considered by the legislature, but there is no requirement that an additional hearing be held on a bill that has been substantively amended after its prescribed hearing. ${ }^{40}$ As a consequence, no public hearings were held on the fair price statute. After the joint judiciary committee's ${ }^{41}$ approval it went directly to the floor of the senate for a vote.

\section{The Role of the Bar}

The third important player in the making of Connecticut's corporation law, and the only organization that opposed the fair price bill, was the executive committee of the corporate law section of the state bar association. The executive committee consists of approximately forty-five members of the over six-hundred-member corporate law section. The leading corporate lawyers in the state serve on the committee. Its origin dates from the early 1960's, when a special committee of the bar was established by legislative act to revamp the stock corporation act. After its work was completed, the committee continued in an unofficial capacity to monitor and update the corporation code.

Although attorneys for Aetna were members of the executive

stances where the amendment process was used to avoid the filing deadline.

10 The procedure's success depends upon the support of the majority party leaders. Amendments can he challenged on the floor and struck from the agenda or subjected to a hearing if they are not germane to the original bill. Party support for the amendment is crucial because the speaker of the house or the president of the senate rules on germaneness. This is why Aetna and the CBIA contacted the majority party leaders to gain their support to introduce the fair price provision. Given this institutional detail, the overwhelming vote for the statute was predictable: only a bill on which there is a powerful consensus will survive the amendment process.

4 The judiciary committee has jurisdiction over corporation laws. All legislative committees in Connecticut are joint committees. 
committee, the committee was not informed of the proposed fair price statute until the day it was favorably reported out of the joint judiciary committee of the legislature. The bill was hastily added to the agenda of the executive committee's monthly meeting, which fortuitously was to be held two days later. At this meeting, the Aetna attorney involved in drafting the provision explained the mechanics of the legislation that his firm was promoting. After some discussion, the committee voted to oppose the bill.2 A majority of the members disapproved of the substance of the bill, but the bulk of the committee's opposition was procedural. They had not been consulted, and they had not had sufficient time to evaluate the merits of the proposal. In addition, a majority of the committee members believed that a significant change to the stock corporation act should not be adopted without full public review. The source of the opposition to the takeover bill was not ideological; attorneys who voted to oppose the statute have divergent views, spanning the political spectrum from liberal to conservative.

In an attempt to slow down what was presented to the executive committee as a fait accompli, members contacted one of the legislative leaders to voice the committee's opposition to the bill's expedited progress. It is believed that the vote on the senate floor was delayed for a few days as a result of this communication. At the same time, an ad hoc committee of the executive committee met with representatives of the CBIA to discuss the statute. But with political support in place,, ${ }^{43}$ Aetna and the CBIA had no intention of acquiescing to delay the legislation by agreeing to a public hear-

12 The committee follows a majority voting rule in its decision to endorse or sponsor legislation. This does not involve the bar association's taking a position-the association rarely endorses legislation because of the unwieldy procedure requiring approval of the board of governors and the entire membersbip. Rather, after clearance by the bar association's president, the executive committee brings its suggestions to the legislature without the association board's endorsement.

4s In fact, according to reports filed witb the Connecticut State Ethics Commission for 1984, botb Aetna and the CBIA took several legislators out to dine, for matters related to lobbying, at the time the amendment was being introduced and reported out of the committee, on Marcb 26 and 28. Tbey also lobbied over meals in February and early March. Of course, the lobbyists' disclosure statements of these events do not reveal the content of the lobbying, and the timing may simply be coincidental. In addition, Aetna's cbairman bosted a buffet in May for the leading politicians in the state, an event that the company reported as unrelated to lobbying activities. There was no sucb event in previous years, althougb, again, the event may have had notbing to do witb the enactment of the fair price provision. 
ing. The best that the executive committee could do was to extract some minor drafting concessions, the most significant of which was an exemption for companies not required to file reports pursuant to sections 13 or 15(d) of the Securities Exchange Act of 1934. This change limited the applicability of the fair price provision to public corporations.

Ten days after the meeting between members of the executive committee and attorneys for the CBIA and its members, the bill passed the senate with only one negative vote. ${ }^{44}$ The bill was approved by the house on the consent calendar two weeks later. Within one month, the governor signed it into law. The fair price provision's legislative journey took slightly more than two months. In keeping with the perceived urgency of the measure, the act's effective date was the day of the signing, June 4, rather than the usual October 1 date.

\section{When Is a Takeover Statute Less Costly than a Charter Amendment?}

Even if the bar had succeeded in its effort to subject the fair price provision to public scrutiny and debate, it is likely that the statute would still have been enacted. The significant difference in outcome, had the ordinary legislative process not been circumvented, most probably would have been a postponement in the bill's effective date. For some reason, then, Aetna and the CBIA must have believed that time was of the essence. In conversations with corporate lawyers, several factors were suggested to me that could have entered into Aetna's calculation to support legislation rather than to engage in self-help by adopting a fair price charter amendment. The simplest explanation, and the only one connected to a concern over timing, is that because Aetna's annual shareholders' meeting had recently been held, Aetna's management would have had either to call a special meeting, which would have been expensive and likely to attract attention, or to wait an uncomfortably long time-close to a year-until the next annual meeting in order to place a fair price proposal in its charter. In this explanation, a straightforward comparison of the cost of the alternative

14 When questioned about bis vote, tbe senator could not recall why he opposed the bill. He was not approached by the corporate law section's executive committee. 
procedures led Aetna to the legislature.

The difference in the timing of obtaining legislation compared to waiting for the next annual meeting could have been crucial for several reasons. For instance, Aetna may have felt the need to hurry if it had been informed that there was unusual trading activity-perhaps the accumulation of a block-in its shares. This concern, if present, would have been heightened by the fact that the insurance industry, including Aetna, was performing poorly. Indeed, Aetna was doing considerably worse than most insurance firms, and several financial reports had published evaluations of Aetna as a below-average investment choice. ${ }^{45}$ These negative recommendations may have made Aetna look like a takeover candidate. In fact, shortly after the statute was enacted, there was a change in Aetna's top management, and the chairman resigned. Given these circumstances, Aetna's counsel may have concluded that the need for a statute was all the more pressing, because in the wake of MITE and the invalidation of Connecticut's general takeover law, ${ }^{46}$ the legality of Connecticut's insurance-company takeover statute might be questioned next, leaving Aetna defenseless: similar laws in other states had had a checkered constitutional fate. ${ }^{47}$

Apart from timing, it is possible that a charter amendment

15 For instance, in March 1984, Value Line's analysis of Aetna reported: "We expect another negative comparison for the March period. . . . We think Aetna will be lucky to report 1984 earnings close to the depressed 1983 level. These shares are a subpar choice for year-ahead relative market performance. ... More attractive 3- to 5-year prospects can be found elsewhere in the [insurance] group in our view." Value Line Investment Survey, Mar. 23, 1984, at 2067. As of March 1984, industry stock price performance was 5\%, Aetna's performance was $-14 \%$, and only three of the total 27 insurance industry group firms had poorer stock performance than Aetna. Trendline's Current Market Perspectives (1984). In addition, Trendline ranked Aetna in the bottom third decile of stocks for that period. Id. For a discussion of Aetna's earnings, see Value Line Investment Survey, Dec. 23, 1983, at 2065, and Value Line Investment Survey, Mar. 23, 1984, at 2067. As early as December 1983, Value Line suggested that despite Aetna's above-average dividend yield, investors could "find higher total returns elsewhere in [the insurance] industry group." Value Line Investment Survey, Dec. 23, 1983, at 2065.

46 Hi-Shear Indus. v. Neiditz, [1981 Transfer Binder] Fed. Sec. L. Rep. (CCH) II 97,805 (D. Conn., Dec. 16, 1980). The statute was then revised to conform to the Williams Act.

47 E.g., National City Lines v. LLC Corp., 687 F.2d 1122, 1128, 1133 (8th Cir. 1982) (Missouri insurance-company takeover statute held unconstitutional). It is no coincidence that in 1985 Connecticut's insurance-company takeover statute was modified to conform its time period requirements to those of the Williams Act. See Conn. Gen. Stat. Ann. $\S 38-39 b$ (West Supp. 1986). 
would not have been approved by the Aetna shareholders, because more than half of Aetna's shares were owned by institutions, which often vote against shark repellent proposals. ${ }^{48}$ In such situations, management will not want to risk rejection. The common wisdom is that it is not the defeat at the ballot box itself that is deadly for managers but the publicity surrounding the failure, for that can signal to potential bidders that shareholder support for incumbent management is weak. Moreover, even if the shareholders approve the proposal, the public disclosure of a shark repellent agenda can serve as a sign to raiders that management perceives the firm to be a likely takeover target. ${ }^{49}$ In this explanation, Aetna favored a statute because it faced less uncertainty over the outcome of the legislature's decision than of a decision by its own shareholders, and because potential acquirers might not be able to identify that Aetna was the concerned party behind the statute.

A final and less persuasive factor for desiring the statutory cloak of anonymity is the embarrassment Aetna might have experienced, as would many institutional investors, in having to take an inconsistent position. In its role as an investor, Aetna may have opposed the adoption of shark repellent amendments by the managements of the firms in which it had equity holdings. If this speculation is correct, it would have been awkward for Aetna's management to place such a provision in its own certificate of incorporation.

Some additional institutional detail might put events in better perspective. Aetna has a history of concern over takeover regulation. As early as 1969, Aetna's counsel testified in support of two bills that would have codified takeover defenses. ${ }^{50}$ One bill, which Aetna could have adopted as a charter provision, would have increased the percentage of shareholders necessary to call a share-

48 When the statute was enacted, between $55 \%$ and $56 \%$ of Aetna's shares were held by institutions. See Standard \& Poor's New York Stock Exchange Stock Reports, Jan. 1984, July 1984. Recent studies on the voting of institutional investors indicating when they oppose shark repellant charter amendments include E. Flax, Voting by Institutional Investors on Corporate Governance Questions, 1985 Proxy Season (Investor Responsibility Research Center 1985); Georgeson \& Co., Institutional Voting on Fair-Pricing and Staggered Board Amendments (1983). The voting behavior of institutions is discussed in Part III, infra.

40 Some managers may want to make their firm a less attractive target by adopting a fair price provision to signal prospective acquirers that they will vigorously resist any unsolicited bid.

so Insurance Comm. Pub. Hearings, 1969 Coun. Gen. Assembly 14-15 (testimony of John Graham, counsel for Aetna, on S.B. 930 and 931). 
holder meeting without board approval from ten to twenty-five percent for insurance companies. The second bill required a holder in street name of ten percent of an insurance company's stock to reveal the identity of the beneficial owner to the company and the state insurance commission. Neither bill was enacted. Instead, the legislature passed a first generation-type takeover statute applicable only to insurance companies, which Aetna also supported. In short, the fair price provision was not the first instance in which Aetna turned to the state legislature instead of its shareholders to devise a mechanism for discouraging takeovers.

\section{A Comparison with the Politics of Connecticut's Previous Takeover Statutes}

I am told that the legislative history of Connecticut's takeover statutes is not in keeping with the way the corporation code is traditionally updated. Usually, the executive committee of the bar is the pivotal sponsor of corporate law reform. There are good reasons for this to be so. First, the committee has far greater expertise in corporate law than any other group in the state. Its membership includes the leading corporate law practitioners. Second, few Connecticut legislators are or have been corporate lawyers, and the legislative committees in Connecticut have small staffs. This makes it virtually impossible for significant revisions in the corporation code to be generated independently by the judiciary committee.

However, the Aetna statute was not the first time that the executive committee was, to use one member's expression, "sandbagged" by the CBIA. The executive committee was not consulted concerning another recent change in the code that touched upon takeovers. In 1982, at a special session of the legislature called for emergency flood relief legislation, the corporation code was revised to reduce the shareholder vote necessary for charter amendments from two-thirds to a simple majority. The prime movers behind the provision were the CBIA and a local firm, the Heublein Corporation. ${ }^{31}$ Heublein, even more so than Aetna, was pressed for time. Heublein's stock was being accumulated by a hostile party, General Cinema Company. Heublein wanted to amend its charter to

s1 Heublein and the CBIA were able to obtain the governor's support for consideration of their bill in the special session. It was suggested to me that, similarly, the governor's office supported the expeditious enactment of Aetna's proposal. 
increase its authorized shares in order to dilute General Cinema's holdings. It would have been unable to do so under the two-thirds voting requirement because of the typical number of shareholders who return proxies at annual meetings-approximately seventy percent ${ }^{52}$ - and the expected no vote of General Cinema's shares.

There was a public hearing on the Heublein amendment during the special session, but at that time the bar's executive committee was in its periodic process of being reconstituted and the newlyappointed chairman had yet to designate formally the committee members. With one week to react and no members to organize, the committee had little opportunity to have an impact on the course of events. It was able to have the proposal revised to exclude nonpublic corporations from the reduced voting requirement, a move that protected the numerous shareholder agreements in small corporations that relied on the two-thirds rule. The adoption of the second generation takeover statute was essentially a replay of the Heublein amendment's legislative history, in which the corporate bar was limited to reacting and carving out exceptions to an important bill. The major difference was that Aetna moved behind the scenes, whereas Heublein publicly sought support for its bill to stop a takeover that was in progress.

Astute observers of Connecticut politics emphasized two possible explanations for the recent decline in influence of the executive committee of the corporate bar. The first is a change in the political environment: the creation of corporate political action committees (PACs) as a source of campaign financing may have increased the influence of the CBIA and other business groups. I was told that ten to fifteen years ago the Connecticut legislature was a quiet and inefficient club that followed the bar's advice and was not especially partisan, but that it is now more subject to the influence of interest groups, with the CBIA emerging as the important advocate for business.

Although possible, I do not find this explanation of the increased importance of PACs and partisanship in state politics particularly convincing. To begin with, the takeover legislation had bipartisan support. Moreover, the CBIA puts far greater resources into its lobbying efforts, at a level relative to other lobbying groups that

\footnotetext{
62 Judiciary Comm. Public Hearings, 1982 Conn. Gen. Assembly Spec. Sess., 12 (statement of Stuart Watson, Chairman of the Board, Heublein Corporation).
} 
does not appear to have changed over time, than into its PAC. For example, in the 1984 election, the CBIA's PAC spent a total of $\$ 14,066$, a sum substantially less than the legal limit, and Aetna's PAC was not active. ${ }^{53} \mathrm{I}$ cannot determine the relative importance of these expenditures because there are as yet no figures available on total PAC spending in Connecticut, but my impression is that they are small..$^{54}$ In addition, it is virtually impossible to attribute a legislator's vote on a particular issue to the direct influence of a specific campaign contribution. ${ }^{55}$ Therefore, even if the CBIA PAC's campaign contributions were substantial, it does not follow that they would have had a discernible, let alone determinative, effect on the voting for the takeover bill.

The second and more persuasive reason suggested to me for the bar's peripheral role in recent legislation involves the subject matter of the bills. The legislature may be willing to go forward without the bar committee's expertise in the takeover context because of the keen interest of strong political forces and the absence of any deep opposition to the regulation. Yet this explanation is not entirely satisfactory either, because the initial effort at regulating the takeover of general stock corporations in Connecticut had a somewhat different history from the Aetna and Heublein amendments. In 1975, the CBIA pushed for a first generation takeover statute requiring preregistration and disclosure by bidders. At the hearing on the bill, the executive committee indicated that it would submit its own bill that would better conform to Connecticut's code. As a result of the disagreement between the CBIA and the executive committee, legislation was delayed until the following session, when a compromise bill was adopted. ${ }^{56}$

This history suggests that, given a part-time legislature and limited staffing, whoever is more effective at educating the legislators about their cause will prevail. ${ }^{.7}$ The CBIA, with its superior lobby-

s3 Aetna organized a PAC in 1984. It was inactive until 1985, when it contributed $\$ 2,000$ to the Insurance Association of Connecticut's PAC.

s4 There are 36 state senators and 151 state representatives, and the PAC contribution limits are $\$ 500$ and $\$ 250$, respectively, per candidate. The amount the CBIA PAC spent is equivalent to making the maximum contribution to $25 \%$ of the total number of seats.

ss See, e.g., Reuben, Tax and PACs: Drawing the Connection, 29 Tax Notes 1335 (1985).

se See Conn. Gen. Stat. Ann. §§ 36-456 to -469 (West 1981 \& Supp. 1986); Banks Comm., Public Hearings, 1976 Conn. Gen. Assembly 136 (statement of Norman Parsells). It is believed that the statute was instigated by a local corporation that feared a hostile bid.

${ }^{67}$ See W. Muir, Legislature (1982) (state legislature is a school in which the legislator is 
ing group and strong stake in takeover legislation, simply overwhelmed the executive committee in the most recent rounds of takeover legislation. To be sure, the strategy of surprise gave the CBIA an edge. But in the takeover context, the CBIA's organizational advantage would be magnified because some of the bar committee's members would, undoubtedly, be reluctant to take a firm public position in order to avoid possible conflict with the wishes of clients.

\section{The Absence of Coalition Politics}

Although the takeover legislation was unopposed in the state legislature, there is no evidence to support a coalition explanation. No nonbusiness group showed any interest in, let alone endorsed, the bill. In particular, organized labor took no position. As a labor representative and lobbyist described its strategy, Connecticut organized labor does not take a position on takeovers in the abstract because it is more important to lobby on issues of greater immediate concern to employees. ${ }^{68}$

In addition to interviewing individuals involved in the statute's enactment, I surveyed all registered lobbyists to see if I had missed, or the parties had forgotten, any source of political support. The questionnaire responses confirmed that the fair price statute was of no interest to anyone beyond Aetna, the CBIA, and the corporate bar. ${ }^{58}$ The absence of notice and publicity concerning

educated by lobbyists and other informed individuals).

s8 For instance, labor did actively lobby in the previous legislative session, 1983, for a plant-closing law, which was defeated. See Labor Scorns CBIA Plant Closing Code, Conn. Bus. J., Jan. 17-23, 1984, at 1, 11. The CBIA vigorously opposed the bill and devised as a compromise a voluntary code of conduct for workplace reduction for its members. Id. To the extent that plant closings sometimes follow hostile takeovers because changes in control can result in "lean and mean" management, labor's support for that bill might be vaguely associated with a coalition explanation of takeover regulation. But even then there was no coalition: business associations uniformly opposed the plant closing bill, most certainly contributing to its defeat.

so Of 661 questionnaires, 229 responded that they took no position on the statute. These numbers are not adjusted for multiple lobbyists and for 16 questionnaires that were returmed as undeliverable. In addition to the CBIA, two respondents-a major corporation and a business association-stated that they took a position in favor of the legislation. These three organizations accounted for seven questionnaires because of multiple lobbyists. Aetna's lobbyists (two questionnaires) informed ine that it is their policy not to participate in surveys. I have no reason to believe that the positions or activities of nonrespondents other than Aetna are distributed differently from those of the respondents. 
the bill surely contributed to a lack of interest in or knowledge of the legislation by lobbyists, but there are other plausible reasons why nonbusiness interest groups would not take a position in favor of the bill. In particular, many Connecticut lobbyists and legislators believe that organizations should not take positions on issues that are not directly linked to their primary cause, because lobbying for a bill that does not directly concern a client may adversely affect subsequent lobbying for the client's bills should legislators draw negative associations between the two unrelated lobbying efforts. ${ }^{60}$ Although broad-based coalitions are effective on occasion, most lobbyists are hesitant to advocate their use.

A related and equally important reason for the lack of interest in the fair price statute by other lobbying groups is that successful lobbying takes time and money. Lobbyists emphasized that even the CBIA, with its substantial budget, directs its attention to no more than two or three major pieces of legislation in a session. The need to prioritize in order to be effective further indicates the importance Aetna attached to the passage of the fair price statute and Aetna's influence within the CBIA.

While there is no evidence of a coalition explanation for Connecticut's second generation takeover statute, legislators who supported the bill may have thought that it would benefit unions or community groups, even though these organizations neither actively lobbied for the bill nor perceived it to be necessarily in their interest. Yet that rhetoric was absent from the abbreviated discussion of the bill. ${ }^{61}$ Such a motive is at best implicit.

A superior explanation of the adoption of Connecticut's fair price provision starts from the thesis that lawmakers react to demands to solve immediate, concrete problems. This is an emendation of the view that organizations are managed by "putting out fires." ioral theory in the state legislature setting, where there are sub-

co Statements made at Connecticut Lobbying Conference, supra note 39.

s1 When the merits of the first takeover statute and the Heublein amendment were discussed, some legislators implied that they supported the bills because limiting takeovers would bolster the local economy by maintaining employment levels. See 1982 Conn. Gen. Assembly, House Proceedings, Spec. Sess. 40-42 (remarks of Rep. Barnes on the Heublein amendment); 1976 Conn. Gen. Assembly, Senate Proceedings 1518 (remarks of Sen. Dinielli on the first generation takeover statute).

c2 See R. Cyert \& J. March, A Behavioral Theory of the Firm 99-100, 118-20 (1963). 
stantial transaction costs to planning because the membership turns over periodically, staffs are small, and the work is often performed part-time. More important, if, as political scientists maintain, voters cast their ballots retrospectively, ${ }^{63}$ the incentives for legislators to respond to immediate problems are great. In this instance, Connecticut legislators were presented with an immediate constituent demand, and there was no opposition except from the executive committee of the bar. Even then, the committee's opposition was not publicized. Any possible political damage from endorsing the bill was negligible, and politically there was something to be gained. Moreover, the business community was united in support of a specific law, and as a consequence, a complex solution did not have to be negotiated among numerous parties.

\section{How Representative Is Connecticut's Experience?}

Although I did not conduct interviews in states other than Connecticut and documentation is sparse, my impression is that the experience of other states is similar to Connecticut's. Local corporations, their lobbying organizations, and state bar groups ${ }^{64}$ were

6s See M. Fiorina, Retrospective Voting in American National Elections (1981).

34 There is variation among the states in the degree of involvement of state bar committees in second generation takeover legislation. In a number of states, in contrast to Connecticut, the corporate bar appears to have been active in initiating a bill. For instance, the Maryland legislation was drafted and revised by the state bar association. Virginia recently updated its entire corporation code, in an official revision process undertaken by the corporate bar, and a fair price provision was included in the final product. In addition, the corporate law section of the state bar association in Washington was responsible for drafting corporation code revisions that included a fair price provision. It is possible that the bar associations in those states have better relations with local legislators than the Connecticut bar, but it is also possible that in those states the source of the proposal was a drafting committee member's client. I was told that the Washington fair price provision, which sailed through the state bar association and the legislature, was the bar committee's response to a local corporation's desire for a statute modeled after Pennsylvania's redemption rights provision.

An additional explanation of the differences in behavior of corporate bar committees might be that recruitment for committee membership varies across the states. In Connecticut, where efforts are made at having the executive committee represent different segments of the corporate bar, the disagreement among the members over the fair price statute may have been colored, as would be expected, by clients' interests. For example, the members who were outside counsel to Aetna and the CBIA supported the bill and did not want the committee to interfere with the legislation's passage, while some members who opposed the law had, as clients, small corporations whose shareholder arrangements could be jeopardized by the provision. It would therefore be important to determine how representative of the corporate bar the members of the committees are in these other states before drawing 
most active in the passage of the bills. More important, the concern of a local firm that it might be acquired was quite often the impetus for the legislation. For instance, in the floor debate on the Maine legislation, one representative referred to the "corporation that was the instigator of (the) bill." "ss In Pennsylvania, the statute was drafted and promoted by the state chamber of commerce at the suggestion of its members and, in particular, of a local corporation that was trying to prevent a shift in control. ${ }^{66}$ In addition, the Illinois statute was apparently promoted by "one prominent Illinois corporation." ${ }^{\prime \prime}$ A sharper example is emergency legislation that extended Missouri's control share acquisition statute to foreign common carriers that have benefitted from physical facilities financed by Missouri subdivisions and that have over 7,500 employees in Missouri. At the time, Trans World Airlines, the only corporation known to meet the statutory requirements, was fending off a takeover by Carl Icahn. ${ }^{68}$

Although the information I have is incomplete, the source of political support for a second generation takeover statute appears to differ somewhat according to the type of provision adopted. In three states, labor endorsed the legislation, and in two of these instances the states were considering control share acquisition provisions rather than fair price or redemption rights statutes. ${ }^{69}$ In Mis-

conclusions.

6s Maine Legislative Record-House, June 3, 1985, at 918 (remarks of Rep. Stevens).

- Pennsylvania Senate is Seen Near Vote on Bill that May Deter Dissident Investors, Wall St. J., Dec. 6, 1983, at 12, col. 1. This is undoubtedly the reason for the particular form of the Pennsylvania statute: A nonmanagement shareholder was trying to increase its $23.7 \%$ holdings, and a fair price provision would not have aided the corporation as well as the redemption rights provision did.

"7 McKenna \& Bitner, The "Fair Price" Amendment in the Illinois Business Corporation Act, 67 Chicago Bar Rec. 64, 74 n.59 (1986).

os See Mo. Ann. Stat. § 351.575(2) (Vernon Supp. 1986). Trans World Airline's respite was short-lived; the amendment was held unconstitutional. See Icahn v. Blunt, 612 F. Supp. 1400, 1414-20 (W.D. Mo. 1985). The technique, however, appears to be common. Kentucky also passed, virtually overnight, a takeover statute to help a local corporation, the Ashland Oil Company, fight a hostile bid. State Helps Ashland Fight Belzberg Bid, The Globe and Mail (Toronto), Apr. 1, 1986, at B3, col 3.

sp The third state was New York, which adopted a fair price provision that had labor's support after the governor had vetoed a fair price and control share acquisition statute. See Sussman \& Sussman, Anti-Takeover Law Set for Litigation, Legal Times of New York, Jan. 20, 1986, at A1, A24-25. The vetoed bill was drafted by the Business Council of New York State, an association of small and large businesses, and reports of the lobbying efforts leading to the governor's veto do not refer to labor's involvement. See Cuomo Vetoes Takeover 
souri, at committee hearings at which no opposition was present, groups identified as testifying in support included two local corporations, a business association, the state chamber of commerce, and the state labor council. ${ }^{70}$ In Ohio, newspaper accounts indicate that the law was supported by the state bar and labor, though it is unclear how active labor was in the initiation, drafting, or lobbying efforts. ${ }^{71}$

It is interesting to note that the control share acquisition statute is more intrusive in the takeover process than a fair price provision because it directly delays an offer. It also provides less leeway for managers to negotiate a deal because board approval does not eliminate the need for a shareholder vote. One possibility is that when labor's support is involved the goal is to discourage bids more decisively by providing more extensive regulation and less managerial discretion to accept an offer. But this is speculation. The information is so sketchy that I would not make much of the distinction.

\section{Why Is There Such Overwhelming Support for Takeover Statutes?}

Despite the minor differences in the lobbying process across states, there is remarkable uniformity in the reaction of state legislatures: the second generation takeover statutes are approved by wide margins, if not by unanimous vote, with virtually no publicity or controversy surrounding their introduction and passage. ${ }^{\mathbf{7 2}}$ There

Curb Bill, New York Times, Aug. 14, 1985, at D1, D2, col. 4.

7o Missouri Legislative History 377 (produced for third reading of bill) (copy on file with the Virginia Law Review Association).

7 See Congress, Ohio Enter Takeover Wars, Plain Dealer (Cleveland), July 31, 1983, at 1E, col. 2.

${ }^{72}$ Of the 14 states with second generation statutes at the time I began this study, the legislative history of Maryland's statute is the only anomaly to the pattern of little or no publicity or controversy concerning the regulation. After the bill passed the Maryland legislature by overwhelming margins and without controversy and the bill reached the governor's desk, several major corporations lobbied against it because, as drafted, it would have disrupted the orderly conduct of their affairs. For example, it would have required a supermajority shareholder vote for the routine sale of jeeps between the Maryland corporation American Motors and its French parent Renault. Maryland Bill on Takeovers Spurs a Fight, Wall St. J., May 26, 1983, at 33, col. 2; Maryland Assembly Panels Pass Corporate Takeover Bill, Washington Post, June 15, 1983, at C4, col. 3. The governor thereupon vetoed the bill and called a special legislative session to revise the statute and remedy the problem by exempting from the statute's reach the corporations that had objected-mutual funds 
is a standard explanation for legislation that generates no significant opposition. Namely, if the benefits of a bill are directed to a specific group and the costs are diffuse, it is likely to be enacted: The benefitted group will lobby intensively for its passage, and no organized opposition will emerge because no one group is particularly burdened by the law. ${ }^{73}$ This explanation is often attached to a logrolling story that is referred to as "pork barrel" politics. In the logrolling explanation, laws are packaged-a notable example is a "rivers and harbors" bill-so that each of the many groups represented in a legislature obtains its desired benefit and the cost of the projects is spread among the entire citizenry.

Takeover laws, however, do not fall neatly within a logrolling explanation. The bills are typically introduced and approved as discrete pieces of legislation. Moreover, there are some identifiable potential losers from this type of legislation: bidding firms and the financial intermediaries who facilitate takeovers. ${ }^{74}$ But this very fact points out a related explanation of the legislators' unanimity

and firms with $10 \%$ shareholders. But even this story confirms the basic pattern in the other states: There was no opposition to the statute's goal of regulating takeovers, and nonbusiness interests were not active in the legislative process.

The experience in New York, when it failed to enact a second generation statute, was similar to that of Maryland. There was little publicity and no opposition in the legislature. But when the legislature passed the bill, a major New York corporation, CBS, was fending off a takeover attempt by Ted Turner in a highly publicized defense, and the bill came to be perceived as an effort hy CBS to thwart Turner's bid. Bcth sides, including Turner's New York investment banker, vigorously lobbied the governor, and he vetoed the bill, questioning its constitutionality and indicating that he would work to draft an alternative bill for introduction in the following session. Gov. Cuomo Vetoes Anti-Takeover Bill for New York State, Wall St. J., Aug. 14, 1985, at 13, col. 4; Major Brokerages Mount Catch-up Bid to Kill Anti-Takeover Bill in New York, Wall St. J., July 1, 1985, at 4, col. 2; New York May Pass Anti-Takeover Bill That Could Help CBS Fight Turner Bid, Wall St. J., June 27, 1985, at 39, col. 2. He in fact did so. Cuomo Bill Offered on Takeovers, N.Y. Times, Oct. 31, 1985, at $\mathrm{D} 1$, col. 3 . In the absence of an ongoing bid, the legislation quite likely would have gone unnoticed and unopposed, as in other states.

Although the presence of investment bankers in New York might make a difference in its politics, New York enacted a second generation statute as this article was written. This statute was also enacted while a hostile bid was in progress, but the New York firm was not covered by the legislation because it was headquartered in Connecticut. There is an important distinguishing feature of the second bill that some believe created a less vociferous opposition. The revised bill was sponsored by the governor. This apparently changed the cost-benefit analysis of opponents of the legislation-the bill was not deemed important enough to incur the wrath of the governor.

73 See J. Buchanan \& G. Tullock, The Calculus of Consent (1962); M. Olson, The Logic of Collective Action 125-31 (1970).

74 Whether target shareholders are losers is analyzed in Part III, infra. 
that emphasizes a disadvantage of a federal system - the benefits and burdens of a law may not be contained within the legislating jurisdiction. When this occurs, interjurisdictional subsidization and exploitation can result, as citizens of the legislating state may benefit from the law while citizens of another state bear the costs. ${ }^{75}$ If acquisition-oriented firms and financial intermediaries do not reside in all states, then takeover legislation could be an excellent example of such an externality-imposing statute, for non-residents, who cannot meaningfully interpose their views in the legislative process, bear the costs. ${ }^{76}$

There is some support for an externality explanation of state takeover legislation. First, the domicile choice of acquiring firms is not random. The largest manufacturing firms incorporated in Delaware have engaged in a greater number of acquisitions averaged over their lifetimes than their counterparts in other states, and, of firms changing their state of incorporation in order to facilitate a mergers and acquisition program, more relocate in Delaware than in any other state. ${ }^{77}$ Thus, it is quite plausible to assume that acquiring firms are disproportionately domiciled in one state, Delaware, and are less likely to be located in other states.

Second, takeover statutes are generally thought to raise the cost of acquisitions. Although one might expect that some of the increase in bid cost might be passed on to the target company shareholders, the empirical research on acquisitions implies that acquiring firms bear all the cost. ${ }^{78}$ In short, the cost that the legislation

${ }^{76}$ A parallel characteristic of lobbying at the national level supporting this explanation is that congressmen are more responsive to interest groups that are constituency-based than to Washington-based lobbyists. See M. Hayes, Lobbyists and Legislators: A Theory of Political Markets 49-50 (1981) (citing J. Kingdon, Congressmen's Voting Decisions 145-46 (1973)).

${ }^{76}$ Ralph Winter distinguished first generation takeover statutes from other corporate laws with a somewhat different externality argument, that by applying to more than domestic corporations, the statutes had an extraterritorial effect and restrained competition, see Winter, State Law, Shareholder Protection, and the Theory of the Corporation, $6 \mathrm{~J}$. Legal Stud. 251, 268, 287-89 (1977), but second generation statutes do not have such broad jurisdictional bases.

77 Romano, supra note 6 , at $255-56,263$. Of course, nearly all Delaware firms are not headquartered in Delaware, and each firm presumably has more influence in the other jurisdiction. But the sheer numbers of firms incorporated in Delaware and the profitability of its charter business make that state highly responsive to firms' desires, despite the lack of physical presence. See id. at 240-42.

${ }^{28}$ The enactment of the Williams Act raised takeover premiums, Jarrell \& Bradley, The Economic Effects of Federal and State Regulation of Cash Tender Offers, 23 J. Law \& Econ. 
may impose would typically be borne by out-of-state acquiring firms. In this regard, it is not a coincidence that Delaware, while a consistent leader in corporate law innovation, was slow to adopt a first generation takeover statute ${ }^{79}$ and has not yet adopted a second generation one. Its legislature is more attuned to a wider mix of corporate interests, including those of acquiring firms, because it has more acquirers within its jurisdiction. In addition, the Delaware legislature acts only upon a proposal's endorsement by the state bar association, whose members represent those diverse interests. ${ }^{80}$ There are also more potential targets in Delaware, which would make the return to acquiring firms and intermediaries from lobbying against takeover legislation higher in Delaware than in any other state. While these potential target firms might desire statutory protection, the presence of acquirers may produce a different equilibrium in Delaware, in which firms rely primarily on self-help.

More important, because hundreds of large corporations are domiciled, though not headquartered, in Delaware, no one firm has the substantial political influence that Aetna, for instance, has in Connecticut. Research on the incorporation decisions of the largest manufacturing firms dovetails with the findings concerning Connecticut's takeover statute. Many large corporations that had not migrated to Delaware believed that moving might adversely affect a highly prized intangible asset, the investments they had made in cultivating local political ties. ${ }^{81}$ The experience in Connecticut suggests that one of the returns on such an investment is the ability to obtain, without much effort, a modern-day version of a special charter, a bill primarily designed to benefit one firm.

$371,373,387-403$ (1980), and, on average, acquiring firms do not experience abnormal returns, while target firms do, Jensen \& Ruback, The Market for Corporate Control: The Scientific Evidence, 11 J. Fin. Econ. 5, 22 (1983).

79 Delaware enacted a first generation takeover statute in 1975. This was seven years after such a statute had heen initially fashioned by Virginia. Six states had already enacted a takeover statute, and four other states also passed such a law in 1975, whereas Delaware was either the first or second state to adopt other important corporate law innovations. See Romano, supra note 6 , at $233-34,24,0,246$. In addition, the Delaware statute was less hostile to bidders than those of other states: it had no hearing requirement, and firms could opt out of its coverage.

so See comments of Judge Andrew Moore in Symposium on the Forces Shaping Corporate Law, 8 Cardozo L. Rev. (forthcoming 1987).

s1 Romano, supra note 6, at 278 . 


\section{Predicting the Adoption of a Second Generation Takeover Statute}

An additional avenue of investigating the adequacy of a coalition explanation, given its inconsistency with the evidence from Connecticut, is to examine which story explains better the pattern of adoption across the states. I did this through a series of regression equations, choosing as explanatory variables factors that capture the gist of the coalition explanation and the putting-out-fires explanation represented by the political experience in Connecticut. A further advantage of this approach is that by increasing the number of observations, the sampling error that can occur from relying primarily on a case study is reduced.

The coalition explanation implies that a state is more likely to enact takeover statutes (1) the more influence organized non-business interest groups have in state politics, because their preferences will tend to be reflected in legislation; and (2) the less economically-prosperous the state, because a change in control of even one firm would be important to the local populace. The puttingout-fires explanation suggests that (1) the larger the number of domestic firms engaging in hostile takeovers, the less likely the passage of a takeover law, because then the business community's interests will not be unified over a statute; (2) the absence of legislative staff and the part-time status of state legislators should affect the legislative output, because without independent staff advice, legislators must rely on lobbyists for evaluation of technical legislation such as a takeover statute and will be less likely to oppose the proposal in the face of strong demand; and (3) a state's economic prosperity is relevant here as well as for the coalition explanation, because to the extent that firms doing poorly tend to be acquisition targets, it is more probable that in economically depressed states a major firm will sponsor a takeover statute.

Several equations were estimated, using logit and probit models in which the dependent variable was the state's binary choice of whether or not to adopt a second generation takeover statute, and ordinary least squares models in which the dependent variable was the state's rank in order of adopting a second generation statute. The predictor variables were chosen from the variables in the following clusters that roughly measure the effects discussed above: (1) variables testing the coalition explanation-the percent of nonagricultural employees who were union members in 1980, and a 
dummy variable for the strength of pressure groups in the state's political process; ${ }^{82}$ (2) variables indicating relative economic prosperity-the percent change in individuals employed in manufacturing from 1980 to 1982 , the percent change in per capita income from 1977 to 1982, per capita income as a percentage of the national average in 1982, and the average rate of unemployment; (3) variables in keeping with the putting-out-fires explanation-the number of domestic NYSE corporations that have engaged in a hostile bid $^{83}$ and dummy variables for full- or part-time legislatures and for whether individual legislators are provided with their own staff. ${ }^{84}$

Because the results did not differ with regression technique, I will discuss only those of the least squares regressions. I estimated a variety of models, using the selection method that maximizes the sample $R^{2}$ and comparing the results with Mallow's $\mathrm{Cp}$ criterion for model selection. ${ }^{85}$ The more complex models did not do significantly better, and in fact did worse, than simpler models; models

\footnotetext{
82 This index was created by a political scientist who divided the states into those where pressure groups are strong (22 states), moderately strong (18 states), and weak (10 states). S. Morehouse, State Politics, Parties and Policy 108-12 (1981).

ss The number of hostile bidders was generated from a database graciously provided to me by John Pound and the staff of the Office of the Chief Economist of the SEC. In addition to using as a regressor the absolute number of domestic NYSE hostile bidders, I also used the percentage of hostile bidders of successful acquirers in the state and of total firms in the state, on the ground that it is relative presence, and not absolute numbers, that matters in influencing the legislature. I also included as a variable the number of domestic NYSE corporations, the direction of which is in theory indeterminate: Although the smaller the number of corporations, the more influence any one firm may have on state politics, the larger the number of firms, the more likely one will be a target desirous of protective legislation. I used a log transformation of this variable on the theory tbat a change from one to two firms would be more significant than a change from 100 to 101 firms. This transformation also mitigates the effect of the observation for Delaware. But I should note that whether I used the log or the raw numbers, in virtually all of the models estimated, the influence of the residual for the Delaware observation was not significant under Cook's D measure of influence. See Cook, Influential Observations in Linear Regression, $74 \mathrm{~J}$. Am. Stat. Ass'n 169 (1979).

"I I also included as a variable the size of the state legislature. This is a factor that can affect the success of special bills, although tbe direction of the effect is in theory indeterminate: In a larger legislature it is cheaper for a lobbyist to "purchase" influence from a legislator-tbe legislator has less monopoly power because he has more competition from other lawmakers-but each legislator's vote is, correspondingly, less influential on the outcome. See R. McCormick \& R. Tollison, Politicians, Legislation and the Economy: An Inquiry into the Interest-Group Theory of Government 29-45 (1981).

ss See G. Judge, W. Griffiths, R. Hill \& T. Lee, The Theory and Practice of Econometrics 862-64 (2d ed. 1985).
} 
containing only five or six variables have most of the explanatory power for the variability in statute adoption as that of the full model. Table one reports the results of three simple models and a full model..$^{86}$

Table one. Regression models for the adoption of a second generation statute.

(a) Full Model:

$$
\begin{aligned}
& \text { Rank }=42.53-.50 \text { Union }-6.51 \operatorname{Ln}(\text { NYSE })+10.37 \% \text { HostileAcqrs } \\
& \text { (.80) } \quad(-1.31) \quad(-1.95) \quad(2.10)^{*} \\
& +6.50 \text { FulltLeg }-.06 \text { Legsize }-5.36 \text { PrfStaff }+6.62 \text { StrongGrp } \\
& \text { (.91) } \quad(-2.03)^{*} \quad(-1.02) \quad \text { (1.22) } \\
& +.67 \text { ModGrp }+7.46 \% \text { ChngeMfg }-1.18 \text { AvUnempl }+.06 \text { Income (\%natav) } \\
& \text { (.14) } \\
& \text { (.15) } \\
& (-.85) \\
& \mathrm{F}=2.59^{*} \quad \mathrm{R}^{2}=.4282
\end{aligned}
$$

(b) Simple Models:

1. Rank $=48.64-.72$ Union -13.44 Ln (NYSE) +.78 Hostile

$$
\begin{aligned}
& (8.62)^{*}(-2.88)^{*} \quad(-4.26)^{*} \quad(2.97)^{*} \\
& +10.11 \% \text { HostileAcqrs }+6.16 \text { FulltLeg } \\
& \text { (2.33)* } \\
& \mathrm{F}=6.65^{*} \quad \mathrm{R}^{2}=.4306
\end{aligned}
$$

2. Rank $=34.07-.75$ Union $-13.9 \operatorname{Ln}($ NYSE $)+4.08$ FulltLeg

$$
(2.92)^{*} \quad(-3.04)^{*} \quad(-4.43)^{*} \quad \text { (.78) }
$$

+.17 Inc(\% natav) +.76 Hostile $+9.21 \%$ Hostile
(1.42)
$(2.94)^{*}$
$(2.13)^{*}$

$$
\mathrm{F}=6.01^{*} \quad \mathrm{R}^{2}=.4561
$$

3. Rank $=35.25-.66$ Union $-7.75 \operatorname{Ln}(\mathrm{NYSE})-.05$ LegSize

$$
\begin{aligned}
(2.80)^{*}(-2.91)^{*}(-2.73)^{*} \quad(-1.89) \\
+.16 \text { Inc(\% natav) }+8.99 \% \text { Hostile }+3.21 \text { StrongGrp }
\end{aligned}
$$

$$
\text { (1.98) }
$$

$$
\mathrm{F}=4.89^{*} \quad \mathrm{R}^{2}=.4054
$$

Note: T-statistics in parentheses.

$*$ = significant at $5 \%$ level.

The regression results offer some support for both explanations of takeover statute adoption. The overall equations were significant and explained approximately forty percent of the variation in

${ }^{86}$ I further chose among the simpler models to report in table one by whether they included variables related to each of the explanations of takeover statute adoption and whether collinearity could be detected by the variance decomposition proportions method. See id. at 902-04. 
rank. There is a significant negative relation between enacting a second generation takeover statute and the presence of domestically incorporated hostile bidders. ${ }^{87}$ There is also a significant positive relation between enacting a statute and having higher union membership and more NYSE firms. In addition, although not statistically significant, the signs of the economic and legislative variables are largely as predicted-economic prosperity and having a full-time legislature are associated with not having adopted takeover legislation. ${ }^{\mathbf{8}}$ Hence, the statistical analyses do not allow us to select with confidence one explanation over the other. However, I prefer the putting-out-fires explanation because, unlike the coalition explanation, it is supported by the regressions, the Connecticut experience, and available data on the enactment of statutes in other states.

\section{The Rationality of Investor Support of Fair Price Provisions}

To the extent that the putting-out-fires explanation fits the totality of the evidence better than the coalition explanation, the incentive effects of the different statutes on shareholders must be examined carefully to determine if the managers promoting the laws are acting in their shareholders' interest. To do so, I first examine the related issue of firms' voluntary actions by analyzing shareholder tender decisions in the context of the different shark repellent rules the statutes codify and identifying when they may benefit some shareholders. Such an explanation should shed light on what gains, if any, can be expected when these provisions are included in corporation codes, and on whether one should anticipate that firms that promote a statute will have anything in com-

\footnotetext{
87 To interpret the results, it is necessary to note that higher ranks indicate the absence of a statute, and hence, a positive coefficient means the variable is related to not having enacted a takeover law.

so The sign of the professional staff dummy variable changed from positive in regressions with fewer variables and with the absolute numher of hostile bidders as a regressor to negative in more complex models or in models without that variable. In addition, the coefficient of the legislative size variable was negative, and significant in some of the regressions as indicated in table one. I have only an ex post explanation: Because second generation takeover statutes are not controversial, the key for a proponent may be to find a legislator willing to introduce the bill, and in a larger-sized legislature it will be cheaper to obtain a sponsor.
} 
mon with the firms that adopt similar charter amendments.

Many commentators maintain that a rational shareholder should not vote for shark repellent charter provisions of the sort that the second generation takeover statutes codify. They contend that rational shareholders vote for antitakeover amendments, although the amendments are not in their interest, out of ignorance, because it is too time-consuming for most shareholders to become informed about the disadvantages of the proposals. ${ }^{89} \mathrm{My}$ starting point is different. Given both the extensive commentary on shark repellent amendments in the press and in legal journals, and the SEC's mandated disclosure in proxy statements of the potential harm to

89 See, e.g., Gilson, The Case Against Shark Repellent Amendments: Structural Limitations on the Enabling Concept, 34 Stan. L. Rev. 775, 824-25 (1982). Gilson further maintains that informed investors such as institutions, although they uniformly vote against such proposals, find little gain in vigorous opposition that would aid in informing other shareholders, because shark repellents are largely ineffective at preventing takeovers. Id. at $825-27$. This is an odd explanation. If shark repellent amendments are as ineffective as Gilson argues, it is difficult to understand why managers desire them or why, to use the Connecticut example, Aetna sought legislation. Furthermore, the voting pattern of sophisticated institutional investors is more complex than Gilson maintains. Institutional voting on shark repellent amendments tends to vary with the size of holdings: Institutions with small blocks vote for, and institutions with large blocks vote against, fair price and other standard shark repellent provisions. Georgeson \& Co., supra note 48 . In addition, institutions are more willing to support fair price provisions than supermajority requirements. Flax, supra note 48 . This voting pattern is in keeping with the findings of SEC, Shark Repellent Amendment Study, supra note 26 , at 5 , that supermajority provisions have a statistically significant negative effect on share prices while fair price provisions do not.

Gilson also speculates that shareholders who support the amendments may actually be informed about the negative effects on takeovers and vote for the provisions hecause of the income they derive from other dealings with the firm that might be disrupted after a change in control. Gilson, supra, at 823-24. He provides the following fanciful example of when this could occur: a shareholder who operates a tavern across the street from a plant of a target fears that the bidder will close the plant, which will reduce the value of the tavern business. Id. However, there is no evidence that shareholders who vote for these amendments are wearing different hats. For instance, there is no data of which I am aware that indicate that the wealth of the shareholders favoring shark repellent amendments depends on relationships with the firm other than their equity investment. Further, as a theoretical matter, the assertion makes little sense. The teaching of modern portfolio theory on the benefits of diversification suggests that an individual would seek to own shares in unrelated companies. One might argue, drawing on option pricing theory, that the tavern owner could buy shares in the target to create a hedge, on the assumption that the target will close the plant when that inaximizes profits and therefore when tavern income goes down, share income goes up. But this reasoning would not suggest that the tavern owner vote for a fair price provision, as Gilson's thesis implies. Finally, and more important, Gilson does not detail the basis-the market failure-for assuming that the plant and tavern will not be able to maximize joint profits when it comes to the decision on closing the plant. 
shareholders of the provisions, it is difficult to imagine that investors have no information about the possible negative effects of such amendments. ${ }^{90}$ Additional anecdotal evidence of the ability of shareholders to vote on charter amendments in an informed fashion can be gleaned from the pattern of adoption of other defensive tactics. Poison pills, which are thought to be the most effective mechanism for defeating hostile bids, ${ }^{91}$ do not require a shareholder vote for their enactment. Managers consistently do not put poison pill plans up for shareholder approval, even though obtaining shareholder ratification could insulate managers from litigation. Other Draconian tactics, such as restructuring the firm's real and financial assets, similarly are not put to a shareholder vote. Both of these defensive strategies have been found to have statistically significant negative effects on shareholder wealth. ${ }^{92}$ The most plausible explanation of management's behavior is that it believes that shareholders would reject a poison pill or restructuring proposal and includes on the proxy agenda only tactics, like fair price provisions, that it knows a majority of shareholders will find acceptable. ${ }^{93} \mathrm{My}$ inclination is, therefore, to reject market failure explanations and to approach the issue from the opposite di-

90 The effect of these amendments on shareholder wealth-or analogously, investors' perceptions of the effect of these amendments on future cash flows-is amhiguous. The findings of studies of the impact of the adoption of shark repellent amendments on share prices are inconclusive, reporting both negative and positive directional effects that typically have no statistical significance. See DeAngelo \& Rice, Antitakeover Charter Amendments and Stockholder Wealth, 11 J. Fin. Econ. 329, 349-55 (1983) (negative direction but not statistically significant); Linn \& McConnell, An Empirical Investigation of the Impact of Antitakeover Amendments on Common Stock Prices, 11 J. Fin. Econ. 361, 378-94 (1983) (positive direction but in most cases not statistically significant); SEC, Shark Repellent Amendment Study, supra note 26 , at $43-44$ (fair price amendments have no statistically significant effect; other shark repellent amendments have statistically siguificant negative effect).

11 See Gilson, supra note 89, at 792-804; Office of the Chief Economist of the SEC, The Economics of Poison Pills (Mar. 5, 1986) [hereinafter SEC, Poison Pills Study].

92 See L. Dann \& H. DeAngelo, Corporate Financial Policy and Corporate Control: A Study of Defensive Adjustments in Asset and Ownership Structure, Managerial Economics Research Center, Graduate School of Management, University of Rochester, Working Paper No. 86-11, at 22-24 (1986); SEC, Poison Pills Study, supra note 91. Dann and DeAngelo's study examines only four types of restructuring -acquisitions, divestitures, stock issuances, and repurchases-undertaken by firms publicly opposing a takeover attempt.

os Proxy solicitation firms typically advise managers on whether their corporation's shareholders will support a proposed shark repellent amendment before management decides to go forward with one. These solicitation firms maintain historical records of the voting patterns of institutional investors on shark repellent provisions and will predict whether an amendment will pass as well as aid in lobbying investors for their support. 
rection by exploring under what circumstances shareholders who are fully informed about takeover rules would still favor shark repellent provisions.

\section{A. A Decision-Tree Analysis of the Decision to Tender}

The incentive effects of shark repellent provisions on shareholders' decisions concerning takeover bids can be evaluated more easily by use of decision trees. The diagrams in figures 1-8 portray the decision problem for shareholders of firms that vary according to whether they are subject to a fair price, plain supermajority, redemption rights, or control share acquisition provision. By convention, squares in a diagram represent decisions and circles indicate uncertain events (events whose outcomes are governed by chance).

The following definitions are used in the diagrams:

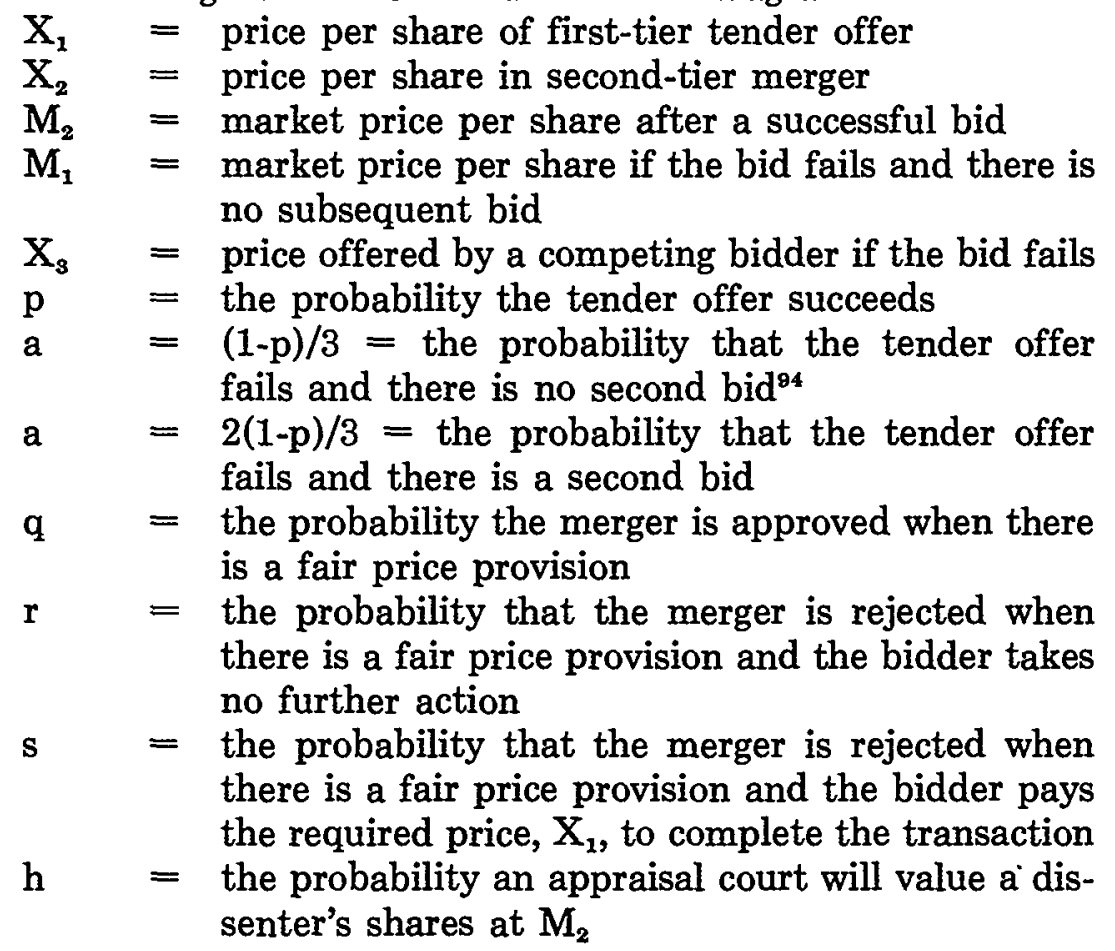

\footnotetext{
24 Approximately two-thirds of firms that reject takeover bids are subsequently acquired in another bid within five years of the defeated offer, and one-third experience no other bid. Bradley, Desai \& Kim, The Rationale Behind Interfirm Tender Offers: Information or Synergy?, 11 J. Fin. Econ. 183, 188 (1983).
} 
$(1-\mathrm{h})=$ the probability an appraisal court will value a dissenter's shares at $\mathrm{X}_{1}$

$\mathrm{n}=$ of the amount by which the probability of the merger's rejection is increased when a shareholder votes no to the merger and the vote matters, the proportion that goes to increasing $r$.

Assumptions derived from empirical research on acquisitions concerning the magnitude of the relative values of the payoffs will be introduced to work through the decision trees. The general structure of the payoffs is:

(0-a) $M_{2}<X_{2}<X_{1}$

(0-b) $\mathrm{M}_{1}<\mathrm{X}_{1}<\mathrm{X}_{\mathrm{s}}$

The first relation indicates the typical structure of a two-step acquisition: the bidder pays a premium to proceed with the merger at the second step $\left(M_{2}<X_{2}\right)$, but the price paid in the second step is less than the price paid in the first step $\left(\mathrm{X}_{2}<\mathrm{X}_{1}\right)$. I ignore the case of an acquisition in which $\mathrm{X}_{2}=\mathrm{X}_{1}$, because a fair price or redemption rights rule is superfluous in that situation. The second relation depicts what happens to the stock price of target firms that reject a takeover bid. When a bid fails, the market price is higher than the bid price, reflecting the expectation that another bid will be made at a price higher than the initial offer $\left(\mathrm{X}_{1}<\mathrm{X}_{3}\right)$, but if no other bid materializes, the market price will drop to the pre-bid level $\left(\mathrm{M}_{1}<\mathrm{X}_{1}\right)^{.95}$

The stylized shareholder's decision is as follows: when a bid is made, the shareholder must decide whether to tender (node 1). ${ }^{96}$ If the tender offer does not succeed, it is possible that there will be a second tender offer at a higher price than the first offer. Typically,

95 Id. at 189-94.

9 There is a third possibility not depicted in the trees that enters into the first decision node: the shareholder can sell in the market instead of tendering. If he exercises that option, he is certain to receive $X_{1}-e$, where $e$ is a small positive amount by which the market discounts the stock below the bid price, presumably for the risk that the bid will fail. Although the market price moves closer to the bid price during the offer period, it does not rise to equal that price even at the close of the offer. Lucian Bebchuk has emphasized, as the argument for eliminating this alternative, that no matter how many times the shares change hands while the bid remains open, the buyer who holds the shares at the time the bid expires inust decide whether or not to tender. See L. Bebchuk, A Model of the Outcome of Takeover Bids, Harvard Law School Program in Law and Economics, Discussion Paper No. 11 , at 34 (1985). 
bidders condition their obligation to purchase tendered shares on the bid's success, but they often acquire the shares even when the bid fails. To avoid unduly complicating the analysis, I assume that a losing bidder purchases all tendered shares unless there will be no subsequent bid..$^{97}$ Hence, to reap the benefits of a higher second offer-to receive $\mathrm{X}_{3}$ - the shareholder must not tender his shares.

If the shareholder does not tender but the offer succeeds, he may have a second decision to make. If the acquiring firm seeks one hundred percent control, it typically cashes out the remaining minority public shareholders in a merger. The second decision is whether to vote for the merger (node 2). In most instances, the acquirer will have obtained enough shares through its tender offer to approve the merger under state law. A no vote, therefore, usually serves to perfect appraisal rights rather than to block the transaction. This is modeled by assuming that the merger always succeeds. The tender offer can be thought of as for fifty percent plus one share, which gives the acquirer a majority of the stock and hence control. With a fair price provision, the yes votes needed for the merger will require more than the acquirer's own shares. Accordingly, probabilities of success and failure for the merger are introduced to value the payoffs of the merger decision of the shareholder whose firm has a fair price provision (figures 2 and 3 ).

This is a simple mapping of the decision process, because the dynamics of competing tenders, as well as the messy bargaining problem involving $n$-person coalitions and the formation of coalitions among shareholders and bidders, are abstracted away. However, it captures many of the pivotal features of the decision problem. The tree can be related to an auction by conceptualizing $X_{1}$ as the highest price offered during the time in which the bid remains open and the withdrawal rights period under the Williams Act is in effect. ${ }^{98} \mathrm{X}_{3}$ is another firm's bid that is made only after the $\mathrm{X}_{1}$ bid

97 The bidder's information about the likelihood of a late competing bid will not be revealed in the stock price prior to the bid's expiration because the bidder does not make bis decision until after the target shareholders have tendered. This factor may be a reason why bidders do not precommit themselves concerning the purchase of shares in the event of defeat.

88 The Williams Act requires bidders to permit tendered shares to be withdrawn at any time during the first 15 days of the bid. 15 U.S.C. $\$ 78 \mathrm{n}(\mathrm{d})(5)$ (1982). The statute extends the withdrawal rights period only if a competing offer is made prior to the expiration date of the initial bid. 
expires. A more serious problem related to the bargaining issue is that the decision trees are a limited illustration of the shareholder's decision, because that decision is embedded in a supergame in which the probabilities of the different responses of the bidder and shareholders are endogenous. ${ }^{99}$ Such an analysis would be technically difficult, if not impossible, to undertake, and would so lack the richness of detail called for in policy analysis, that it is questionable whether any commensurate analytical advantage would be obtained.

Before working through the decision problem, a final word that places my use of decision trees in the context of recent scholarship is in order. William Carney and Lucian Bebchuk have advanced important explanations of the shareholder's tender decision. Carney structures the payoffs to shareholders from takeovers as a prisoner's dilemma game. ${ }^{100}$ The investor's decision strategy in this game is always to tender, which is suboptimal because the payoff from such a strategy is less than the payoff that would be received if no one tenders and the shareholders as a group hold out for a higher price. Carney contends that shark repellent amendments are mechanisms that solve the game's coordination problem and allow shareholders to reach the more optimal strategy of not tendering. While I agree with Carney that shark repellent amendments can benefit shareholders by enabling them to reject a bid, in his model no shareholder would retain shares in the absence of a shark repellent amendment. Yet in the real world not all bids are accepted, and this is true whether or not a firm's charter has shark repellent provisions. Accordingly, it is useful to analyze the problem with a more realistic payoff structure, to determine when a strategy of not tendering emerges.

Bebchuk has developed a formal model of the shareholder's decision that, unhike Carney's, does have an equilibrium strategy in which shareholders do not tender their shares. To obtain nontendering as a unique equilibrium, Bebchuk models the share-

\footnotetext{
OUnless the game flips the probabilities in a strange way, my results will be the same as those in the supergame. An additional caveat along these lines is that in order to obtain specific decision rules I use average premium values. If these values vary systematically with firm ownership structure or other characteristics of the target, the results could change in an undetermined way.

${ }^{100}$ See Carney, Sbareholder Coordination Costs, Shark Repellents, and Takeout Mergers: The Case Against Fiduciary Duties, 1983 Am. Bar Found. Res. J. 341.
} 
holder's choice problem as each investor's having a different valuation of the firm. ${ }^{101}$ The shareholder compares his valuation to the bid and the expected market price if the bid should fail at the same time that he considers his estimate of other shareholders' values. I did not adopt this model because I doubt that shareholders value their shares significantly higher than bidders. I chose instead a model that eliminates the valuation problem and is in the spirit of the discussion in another article by Bebchuk that focuses on differences in bid and market prices and probabilities of outcomes rather than on differences in shareholders' valuations. ${ }^{102}$

\section{Decision When There Is No Shark Repellent Provision}

The key to a decision tree is that the sequential analysis works back from the last decision towards the initial decision. ${ }^{103}$ The first decision solved is the last decision in the tree. One then moves backward, discarding the consequences for the alternatives that one knows will not be chosen to evaluate the particular antecedent decision node. This is continued until the initial decision is reached, which is treated hike any other decision. For simplicity, the method for choosing among alternatives that I adopt uses expected values, which is the same as assuming that shareholders are risk neutral. ${ }^{104}$

Consider the decision portrayed in figure 1 of a shareholder in a firm without any shark repellent provision. The first decision to consider is the decision at node 2 , the vote on the merger proposal, which is the final decision in the "do not tender" branch of the tree. If one of the following assumptions concerning appraisal rights is made: (1)shareholders will not enforce their appraisal rights because it is very costly; or (2)the appraisal court will always choose $M_{2}$, the market value after a successful bid, as the value of

101 See Bebchuk, supra note 96.

102 See Bebchuk, Towards Undistorted Choice and Equal Treatment in Corporate Takeovers, 98 Harv. L. Rev. 1.693 (1985).

103 For an excellent textbook on decision anaylsis, see C. Holloway, Decision making Under Uncertainty: Models and Choices (1979).

104 This is a reasonable assumption that can be justified by portfolio theory-investors are diversified and hence risk neutral with respect to any one firm. If the outcome of bids is correlated with market risk, then this justification would be inapposite. My hunch is, however, that the results of the analysis would not be changed much if I assumed risk aversion. 
Figure 1. Decision when there is no shark repellent provision.

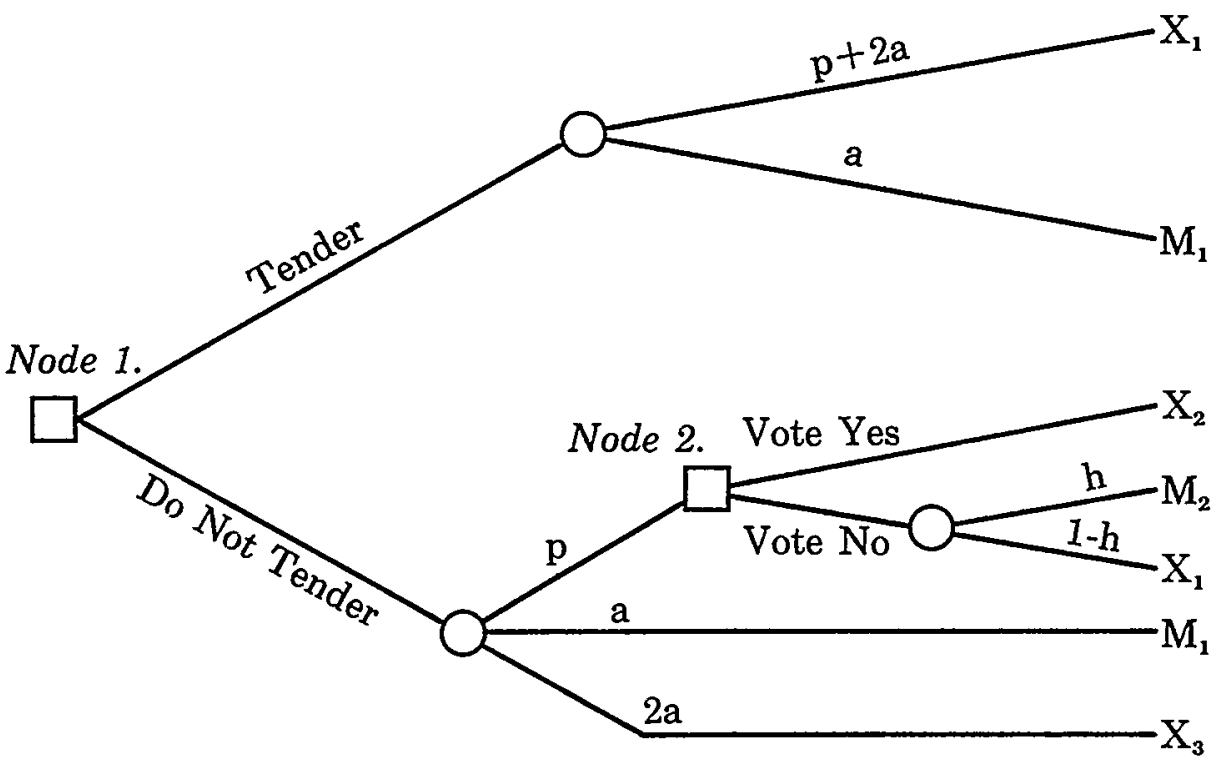

the stock, then this is a straightforward decision because of pure outcome dominance- $-M_{2}$ is less than $X_{2}$. The decision rule is vote yes.

If it is assumed, instead, that appraisal rights will be exercised and there is a positive probability, 1-h, that the appraisal court will value the shares at $\mathrm{X}_{1}$, then the shareholder votes yes or no on the merger depending on the value of $h$. By introducing an additional assumption concerning the relative value of $M_{2}$, one can solve explicitly for the critical value of $h$. I adopt the assumption, based on the stock vglue of target firms that are not inerged out, that:

(1) $\mathrm{M}_{2}=.59 \mathrm{X}_{1}{ }^{105}$

103 See Office of the Chief Economist of the SEC, The Economics of Any-or-All, Partial, and Two-Tier Tender Offers 19 (Apr. 19, 1985) [hereinafter cited as SEC, Partials Study] (on average, premium in second step is $44.8 \%$ above market price; per share value of first step is $15.7 \%$ greater than per share value of second step). 
The decision rule is vote yes if $h$ is greater than .34; vote no if $h$ is less than .34. If the maximum value the appraisal court finds is greater than $X_{1}$, the cutoff value of $h$ is higher. To simplify the presentation, the calculations for all the decisions in each tree are provided in the appendix. For the discussion in the text, I assume that $\mathrm{X}_{1}$ is the maximum amount the appraisal court will award; in the appendix I include the adjustments to the decision rule when the maximum amount is $X_{3}$, which is higher than $X_{1}$. The adjustments are, for the most part, trivial.

From this resolution of the decision at node 2, one moves back to the decision at node 1 , to tender or not, and compares the outcomes of tendering with those of not tendering and voting yes or voting no. To determine the optimal choice in this case, some additional assumptions concerning the values of the payoffs must be introduced. Again, all values used are derived from the empirical research on acquisitions.

(2) $\mathrm{X}_{2}=.86 \mathrm{X}_{1}{ }^{106}$

(3) $\mathrm{M}_{1}=.61 \mathrm{X}_{1}{ }^{107}$

(4) $\mathrm{X}_{3}=1.17 \mathrm{X}_{1}^{108}$

If $h>.34$, so the shareholder votes yes (which is equivalent to the rollback in the case where appraisal rights are not exercised), the shareholder tenders if $.14 \mathrm{p}>.34 \mathrm{a}$ or, substituting for $\mathrm{a}$, which equals $(1-p) / 3$, the shareholder tenders if $p>.45$. If $h<.34$, so he voted no, then the shareholder tenders if $.41 \mathrm{ph}>.34 \mathrm{a}$. Since $h<.34$, the critical value for $\mathrm{p}$ here is always greater than its value when the shareholder votes yes. The closer $h$ is to .34 , the closer the critical value of $p$ is to .45 . As $h$ decreases, the critical value of $p$ increases. For example, if $h=.1$, then the shareholder tenders if $\mathrm{p}>$.73. The more likely the appraisal court is to value the shares at $X_{1}$, which is greater than the market price, $M_{2}$, the less likely the shareholder is to tender his shares.

One permutation of figure 1 needs to be considered. There is a

${ }^{106}$ See Id. (on average, per share value of first step is 15.7 percent greater than per share value of second step).

${ }^{107}$ See Id. (first-tier average premium $62.8 \%$ ). I use this premium to determine $\mathrm{M}_{3}$ hecause when there is no subsequent acquisition the share price reverts to the market price before the initial bid. See Bradley, Desai \& Kim, supra note 94, at 189-94.

${ }^{103}$ See Jarrell, The Wealth Effects of Litigation by Targets: Do Interests Diverge in a Merge?, 28 J. L. \& Econ. 151, 168-69 (1985) (auction results in average gain of $17 \%$ over initial bid). 
question concerning what happens to the decision if the shareholder sees through to the blended premium, that is, he understands that half of his shares will be purchased at $\mathrm{X}_{1}$ and the remaining half at $\mathrm{X}_{2}$. Consider first the case when $\mathrm{h}>.34$, so that the optimal choice is vote yes on the merger. When the shareholder recognizes that not all his shares will receive the higher first-step price, the decision rule changes to tender if $p>.86$. Thus the cutoff probability used for deciding to tender nearly doubles when the shareholder recognizes that he will receive $\mathrm{X}_{1}$ for only half of his shares, and accordingly, there are more cases in which the choice of not tendering is optimal, so he is more likely not to tender. Because the shareholder realizes that he will actually receive less than $X_{1}$ if the tender succeeds, the higher possibility of receiving $X_{3}$ from another bidder weighs more importantly in his decision than the less likely downside risk of getting only $M_{1}$. In the case where $\mathrm{h}<.34$, so that the shareholder votes no on the merger, the decision rule when the blended premium is recognized changes to tender if $\mathrm{ph}>1.34 \mathrm{a} / .205$. The right-hand side of this equation is always greater than the right-hand side of the equation of the decision rule for $h<.34$ when the shareholder does not see through to the blended premium, which was tender if $\mathrm{ph}>.34 \mathrm{a} / .41$ (that is, 6.53a $>.829 a$ ).

Hence, the direction of change is the same in both decision problems: the cases in which a shareholder will not tender increase when the blended premium is taken into account. However, these results follow only from maintaining the assumption that $\mathrm{X}_{\mathbf{3}}$ does not decline proportionately to seventeen percent above the blended premium of $.5\left(\mathrm{X}_{1}+\mathrm{X}_{2}\right)$, rather than seventeen percent above $\mathrm{X}_{1}$. If $\mathrm{X}_{3}$ is so adjusted, and there is no reason to assume that the subsequent bid does not involve such a response, recognition of the blended premium would have no effect on the decision rule. I follow this convention for the rest of the paper and ignore the blended values. ${ }^{109}$

100 All results carry through if a blended premium is used. I calculated the decision rules for all of the trees using a value for $X_{1}$ that was equal to the average blended premium of approximately fifty percent, see SEC, Partials Study, supra note 105, and found no significant change in any of the decision rule choices. 
2. Decision When There Is a Fair Price Rule

Figure 2 depicts the decision for a shareholder when a firm has a fair price provision in its charter. The success of the merger is

Figure 2. Decision when there is a fair price rule.

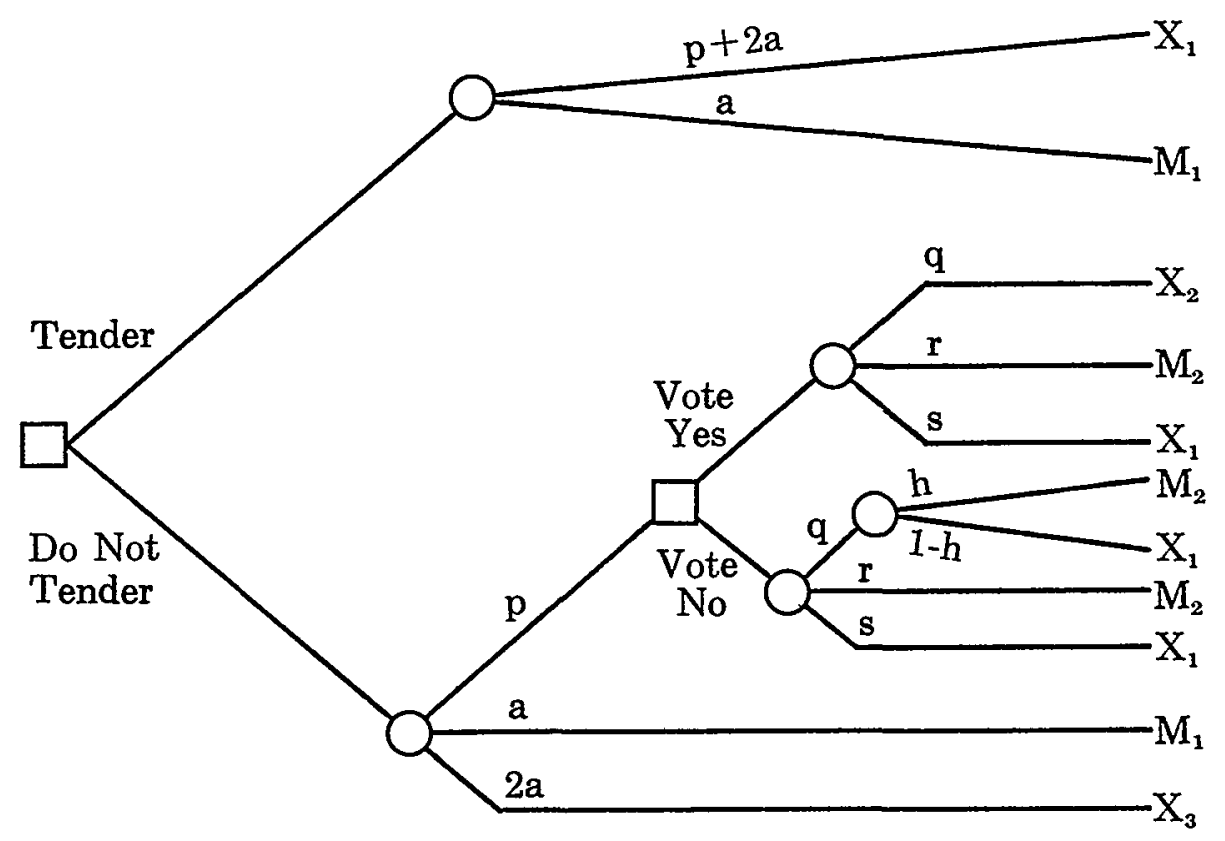

no longer certain because the votes of the acquirer's own shares will not be sufficient for approval. The payoff $\mathrm{M}_{2}$, the trading price of the shares after a successful bid if the merger is rejected, can also be interpreted as the payoff shareholders receive when neither a supermajority vote nor payment of a fair price is necessary because management has approved the transaction. This would imply that management and the bidder split the difference between $X_{2}$ and $M_{2}$. As before, the merger vote depends on $h$ : the shareholder votes yes if $h>.34$ and no if $h<.34$. Similarly, under the assumption that appraisal rights are not exercised, he always votes yes.

The interesting question is to compare the tender decision contingent on each of the two possible merger votes to the tender decision when there is no fair price provision. The strongest argu- 
ment against shark repellent amendments is their disincentive effect on target shareholders to tender, and derivatively, on bidding firms to make acquisitions. As Sanford Grossman and Oliver Hart have demonstrated, a level price rule may have undesirable incentive effects on shareholders because of inertia-there is little reason for shareholders to tender rather than to wait and see what develops because they will receive the same price in any event. ${ }^{110}$ As a result, the probability that a bid will fail is increased, and this effect, Grossman and Hart maintain, will feed back into the market for corporate control such that the number of initial acquisition attempts will decrease.

When $\mathrm{h}>.34$ and the optimal choice is to vote yes on the merger, the decision to tender is a function of the relative values of the probabilities. Namely, the rule is to tender if $p>.34 a /(1-$ $.86 \mathrm{q}-.59 \mathrm{r}-\mathrm{s})$. This result can be compared to the decision rule without a fair price provision, which was tender if $p>.34 a / .14$. The shareholder's decision is the same if $1-.86 \mathrm{q}-.59 \mathrm{r}-\mathrm{s}=.14$. If the expression on the left-hand side is less than .14, the shareholder will be less likely to tender when there is a fair price rule in place than without one, because he tenders when the probability of the bid's success, $p$, is greater than .34 a divided by this value, and the smaller the value of the expression compared to .14, the fewer values $\mathrm{p}$ can take for which the decision rule to tender holds. Another way of interpreting the results is to see that the fair price rule has no effect when $1.9 \mathrm{r}=\mathrm{s}$, the likelihood of paying a fair price is about twice the likelihood of not merging. If $\mathrm{r}<.53 \mathrm{~s}$, shareholders will tender less frequently with a fair price rule than without one. The expectation of receiving $\mathrm{X}_{1}$ as a floor leads the shareholder not to tender in the hope of realizing $X_{3}$.

When $\mathrm{h}<.34$ and the optimal choice is to vote no on the merger, the decision rule is to tender if $p>.34 a /(.41 r+.41 q h)$. The fair price provision has no effect on the shareholder's decision when the merger vote is no, if $.41 \mathrm{r}+.41 \mathrm{qh}=.41 \mathrm{~h}$, or, $\mathrm{r}=[\mathrm{h} /$ (1-h)]s. If the left-hand side is less than the right-hand side, the shareholder will tender less frequently with a fair price rule-because $h<.34$, the right-hand side can be no more than .51s. Shareholders favor a rule, then, depending upon the likeli-

220 See Grossman \& Hart, supra note 24; Easterbrook \& Fischel, Corporate Control Transactions, 91 Yale L. J. 698, 710-11 (1982). 
hood of the bidder's courses of action. In both cases, vote yes and vote no, if $s$ is more than about two times $r$, the shareholder tenders less frequently with a fair price rule than without one.

These results show when it is more likely that a shareholder will not tender with a fair price rule in place than without one. They are the conditions under which the inertia argument holds. The analysis suggests that a fair price provision does not always imply an inertia effect. Without information on the probabilities, in particular the probability of bidders' reactions, one cannot conclude that these provisions definitely affect the probability of a bid's success and hence the likelihood of the occurrence of the initial bid for the particular firm or of bids in general. But in fairness to Grossman and Hart, the fair price rule they envisioned is not what shareholders actually adopt but rather one similar to a redemption rights statute. In their model they assume the bidder must always pay $\mathrm{X}_{1}$ in the second step. The reason why the shareholder sometimes tenders in my analysis is because the bidder need not always pay the fair price.

A question that the decision tree analysis does not address is how $\mathrm{X}_{1}$ (the price per share of the first-tier tender offer) compares under the different rules. If a bidder has only a fixed sum to pay for a target's shares, the level price $X_{1}$ paid for a firm with a fair price provision will be less than the $\mathrm{X}_{1}$ and more than the $\mathrm{X}_{2}$ (the price per share in the second-tier merger) paid to a firm without the rule. The bidder thereby pays the same aggregate amount in either case. In this scenario, the primary effect of a fair price provision is distributional, and it might not affect the frequency of bids. ${ }^{111}$ On the other side, because the fair price provision might reduce the incentive to tender, the bidder might still have to offer a higher $\mathrm{X}_{1}$, such that the difference between $\mathrm{X}_{1}$ and $\mathrm{X}_{3}$ (the price offered by a competing bidder if the bid fails) is small, to ensure that shareholders tender. The probability of a takeover would be reduced if the value of $\mathrm{X}_{1}$ that was necessary for the tender offer to succeed with a fair price provision compared to that without such a rule would make the acquisition unprofitable. In such mar-

\footnotetext{
111 Cf. J. Pound, The Impact of Antitakeover Charter Amendments on Contests for Corporate Control (Investor Responsibility Research Center 1985) (firms with shark repellent provisions have lower frequency of takeover bid and similar premium size as firms with no provisions).
} 
ginal cases, the shareholder considering a fair price rule has to weigh the reduction in the firm's probability of being the object of a bid in the presence of the rule against the decreased likelihood of receiving a premium for his shares in the absence of the rule.

Without knowing the magnitude of the decline in probabilities and of the difference in offering prices, it is not possible to determine the optimal decision, except for shareholders for whom the likelihood of receiving a premium in the first step is almost certain. For such an investor, it is unambiguously better not to have the rule because he always receives the bid premium and there will be no decrease in the possibility of a bid. A fair price rule could lower the return of these investors. Part B examines more systematically who such shareholders may be.

But there is a further complication: The adoption of a fair price charter provision may bring the firm to the attention of bidders, and thereby increase the likelihood of a bid.12 In this circumstance, the aforementioned shareholder might not disapprove of the provision. Moreover, to the extent that a fair price provision reduces the risk of not tendering and enables a shareholder to wait for a higher competing bid, and if the effect on the frequency of an initial bid is small, then these shareholders may again benefit from such a provision. At the other end of the spectrum, for shareholders for whom the probability of receiving a premium in the first step is close to zero, the decreased likelihood of a tender offer obviously has less impact on the value of their shares. Part B will consider the identity of this set of shareholders and will indicate when we might expect them to conclude that a fair price rule is to their benefit.

\section{Fair Price Rule When Decision Affects the Probability of the Merger}

Figure 3 changes the assumption of price-taking, that the shareholder's vote does not affect the outcome of the merger. It illustrates the decision tree for a shareholder, owning shares in a firm with a fair price rule, whose decision affects the probabilities of the

112 This signaling thesis is tbe explanation that would be offered for the typical finding that the adoption of shark repellent amendments has no statistically significant negative effect on share prices by those who believe that such provisions harm shareholders. See Romano, supra note 6, at 270-71. 
outcomes. In this scenario, a decision to vote no decreases the likelihood of the bidder's success and a decision to vote yes increases the likelihood of the bidder's success. This impact is plausible

Figure 3. Fair price rule, decision affects outcome.

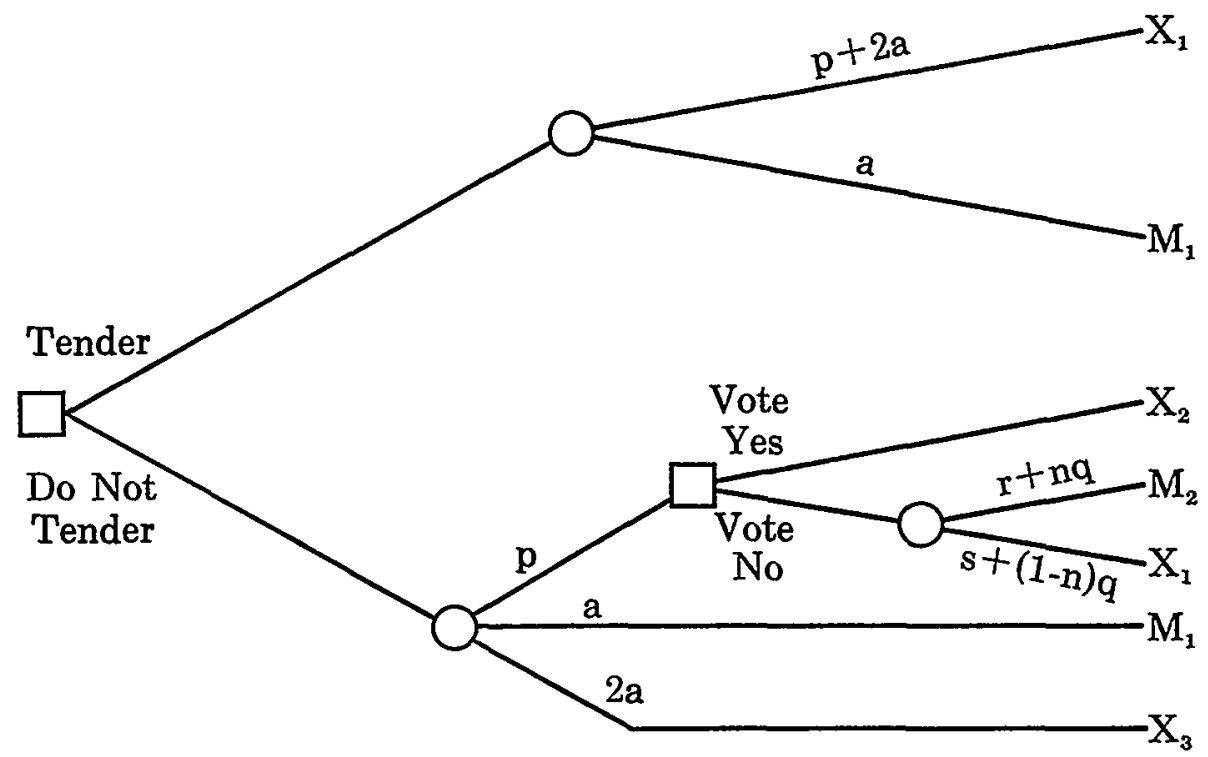

even for a shareholder with relatively small holdings because of the supermajority vote requirement for the combination. Given the typical turnout of votes in publicly-traded corporations of between seventy and eighty percent of the outstanding shares, an eighty percent, two-thirds disinterested shares rule is, in effect, a requirement approaching unanimity. Recognizing this, a simplifying assumption is adopted:

(5) If the shareholder votes no on the merger with a fair price rule, $q=0$. If he votes yes, $q=1$.

The rationale for making a symmetric assumption concerning a yes vote's effect on the merger's success follows the logic of a Nash equilibrium: all marginal shareholders face the same decision tree, know they are the swing vote, and consequently make the same choice. Thus, voting yes means the merger will succeed. For techni- 
cal convenience, I assign to the payoffs of $\mathrm{M}_{2}$ and $\mathrm{X}_{1}$ the probabilities, respectively, of $r+n q$ and $s+(1-n) q$, when the merger is rejected.

Working backward through the tree, the decision rule is, if nq, the relative amount by which $r$, the probability of no combination, increases, is greater than .34-r, vote yes; if it is less, vote no. When $\mathrm{nq}>.34-\mathrm{r}$ and the shareholder votes yes, the decision rule for tendering is the same as that with no fair price provision(figure 1). The two trees are the same, because voting yes now assures receiving $\mathrm{X}_{2}$, just as it did with no shark repellent amendment when the bidder's shares controlled the merger outcome. When nq $<.34-\mathrm{r}$ and the shareholder votes no, the shareholder tenders if $\mathrm{p}>.34 \mathrm{a} /$ $(.41 \mathrm{r}+.41 \mathrm{nq})$. In this case, the decision to tender is the same as that without a fair price rule when $r+n q=h$. Therefore, if $r+n q>h$, the shareholder tenders more with a fair price rule than without one. If $n=h$, the decision rule is the same with a fair price rule whether or not the shareholder's no vote affects the merger outcome.

\section{Decision When There Is a Plain Supermajority Rule}

To ensure that its bid succeeds, the bidder might threaten that it will not undertake the merger if it has to pay more than $\mathrm{X}_{2}$. In the extreme case where $s=0$, we are, in effect, dealing with a plain supermajority provision. Figures 4 and 5 portray the decision rule when the shark repellent device is solely the supermajority component of a fair price provision. In brief, when a no vote stops the merger, the shareholder always votes yes because the merger entails a premium above the market value of the shares (figure 4). This is a case of pure outcome dominance identical to the merger decision with no shark repellent amendment and no exercise of appraisal rights. The shareholder tenders if $.14 \mathrm{p}>.34 \mathrm{a}$, which is the same decision rule as the rule applied when there is no shark repellent amendment. When a no vote does not necessarily cause the merger to be rejected and appraisal rights are available to the dissenter, (figure 5), the shareholder votes yes when $\mathrm{h}>\mathrm{r}+\mathrm{s}+.35 \mathrm{q}$. This means that, all other things being 
Figure 4. Supermajority rule, decision affects outcome.

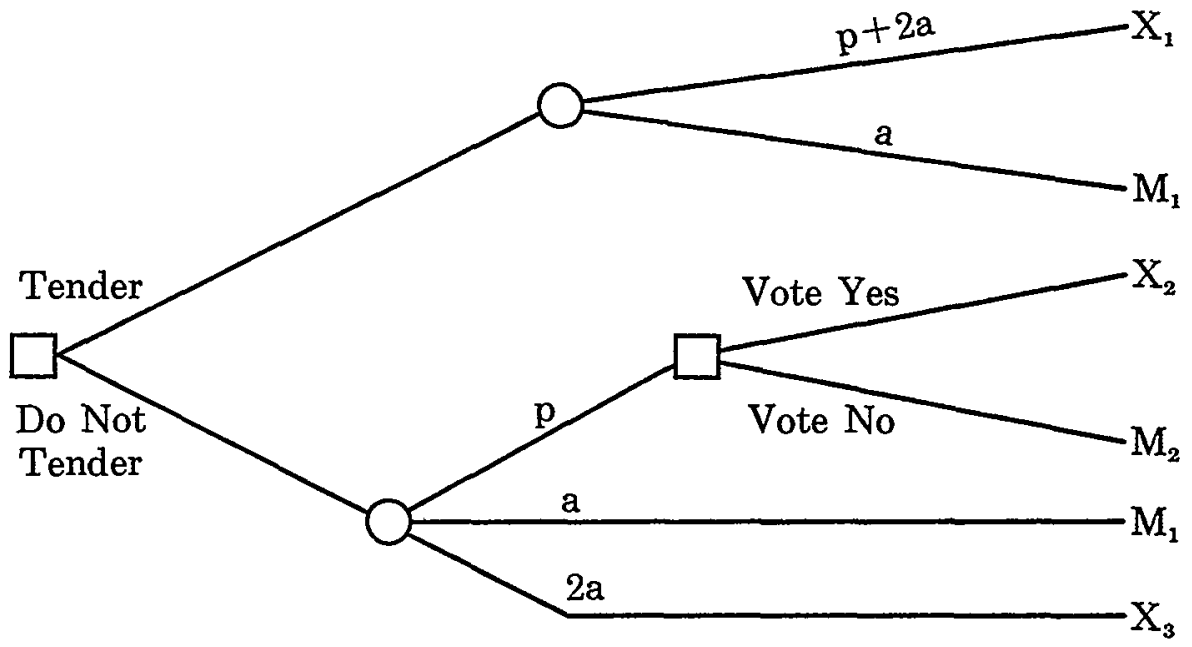

Figure 5. Decision when there is a plain supermajority rule.

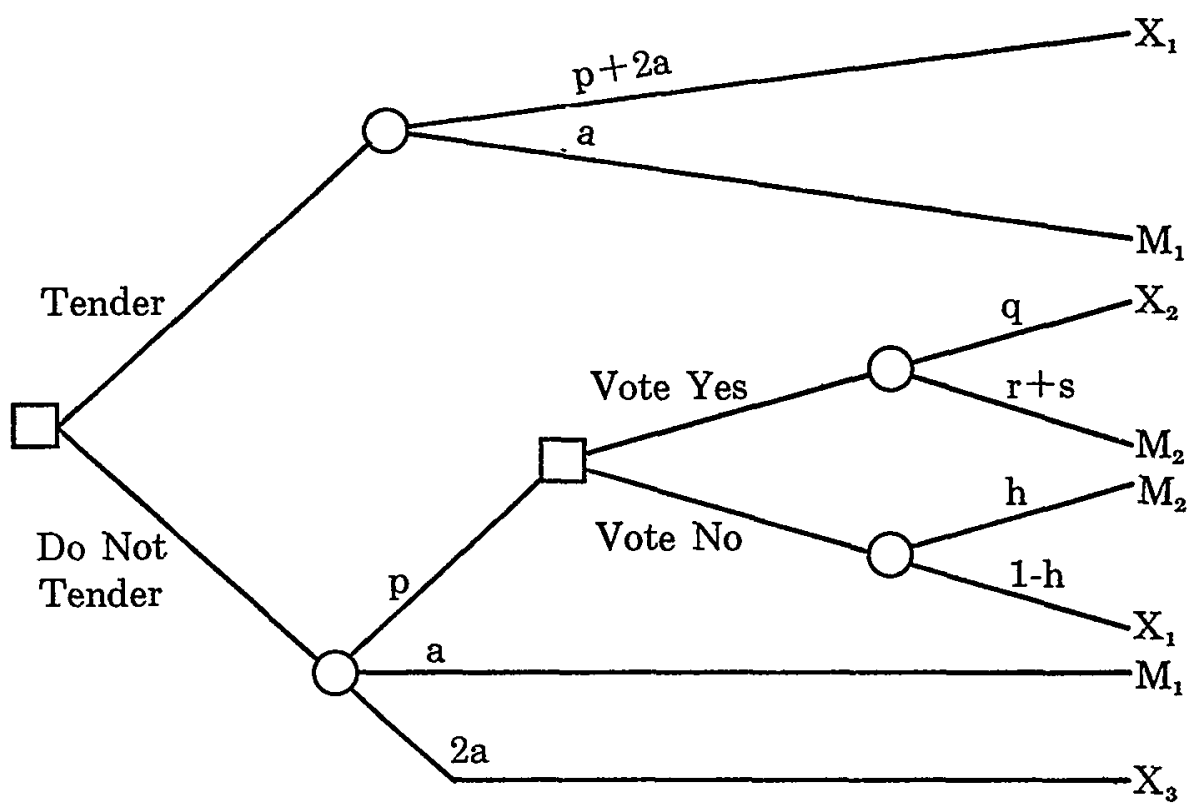


equal, shareholders will approve the second step merger in more cases with a plain supermajority rule than with a fair price rule or no shark repellent amendment, when 1-.65q $<.34$.

To see the effect of the supermajority provision on the tender decision, I compare first the decision rule for the case when the shareholder votes yes on the merger. The optimal choice is to tender if $\mathrm{p}>.34 \mathrm{a} /(.41-.27 \mathrm{q})$. The shareholder will tender more frequently with a supermajority rule than when such a rule is part of a fair price package if .41-.27q $>1-.86 q-.59 r-s$. Substituting and rearranging terms, this reduces to $1.6 \mathrm{~s}>\mathrm{s}$, and the shareholder always tenders more frequently with a supermajority provision than with a fair price rule. He will tender more frequently with a supermajority rule than with no shark repellent at all if .41$.27 q>.14$. For the case when the shareholder votes no and the vote does not guarantee that the merger fails, the shareholder tenders if $.41 \mathrm{ph}>.34 \mathrm{a}$, which is the same decision rule as the one with no shark repellent amendment. The shareholder will therefore tender more frequently when there is a plain supermajority provision than when a supermajority provision is accompanied by a fair price option if he votes yes to the merger, and if he votes no and $\mathbf{r}<[\mathrm{h} /(1-\mathrm{h})] \mathrm{s}$.

The result suggests that shareholders might be better off with a fair price provision than with a supermajority provision, assuming that shareholders benefit from not tendering. This effect supports a learning explanation of why plam supermajority provisions have become less popular over time and have been replaced with supermajority requirements that are attached to fair price rules. Of course, in the case of a plain supermajority provision, when the requisite vote of approval is not obtained, nothing stops the bidder from simply raising its merger price up to the fair price $X_{1}$ and seeking another vote.

Despite the likely reduction in shares tendered, bidders might also prefer a fair price provision to an unadorned supermajority clause. The fair price option offers the bidder who desires one hundred percent control a way to avoid a supermajority vote that increases the holdout power of a small number of shareholders. If the bidder pays $X_{1}$, it does not need to attain a supermajority's approval of the merger, and its own controlling shares will be enough 
to consummate the transaction. ${ }^{113}$ There is also the option of obtaining management's approval, which presumably is exercised if it costs less than paying the $\mathrm{X}_{2} \leq \mathrm{X}_{1}$ that attracts sufficient shares. One can safely assume that the bidder will choose the cheapest course of action, under a fair price provision, from among obtaining board approval, shareholder approval, or paying the fair price.

From this perspective, a fair price provision may reduce the transaction costs of an acquisition rather than, as is commonly presumed, increase those costs. The bidder does not have to worry about the price it must pay in the second step. All it has to pay is $X_{1}$, the price the shareholders have agreed to accept in advance in the fair price clause. Negotiation and litigation costs are thereby substantially reduced. In this setting, it is unlikely that a shareholder would receive more than $\mathrm{X}_{1}$ in an appraisal proceeding and, presumably, shareholders are aware of this and will be less likely to pursue such a remedy when the terms of the fair price provision are fulfilled. The clause thus provides a ceiling, rather than a floor, for the purchase price.

\section{Decision When the Firm Is Subject to a Redemption Rights or Control Share Acquisition Provision.}

Some straightforward comparisons can be made between fair price provisions and redemption rights and control share acquisition statutes. These statutes resemble different features that are combined in a fair price provision. Because these statutes are triggered by acquisitive transactions regardless of a two-step structure, I discuss the shareholder's decision problem for both statutes as consisting of one decision on tendering. However, the decision rules are unchanged if the problem is depicted as a two-tier offer entailing two decisions, tendering and voting on a second-step merger (see figures $6 \mathrm{a}$ and $7 \mathrm{~b}$ and appendix).

A redemption rights scheme is equivalent to a mandatory fair price requirement. The payoff that the shareholder receives if he does not tender and the bid succeeds is certain to be $X_{1}$. Figure 6

\footnotetext{
12 This advantage would not be available if, as is commonly claimed, the bidder makes a two-tier offer because it cannot obtain the financing to pay cash for all the shares, which means that in the second step the bidder must use securities that will sell below their face value such that $\mathrm{X}_{2}<\mathrm{X}_{2}$.
} 
illustrates the decision problem for a shareholder in a firm subject to a redemption rights statute. As long as there is a positive prob-

Figure 6. Decision when there is a redemption rights rule.

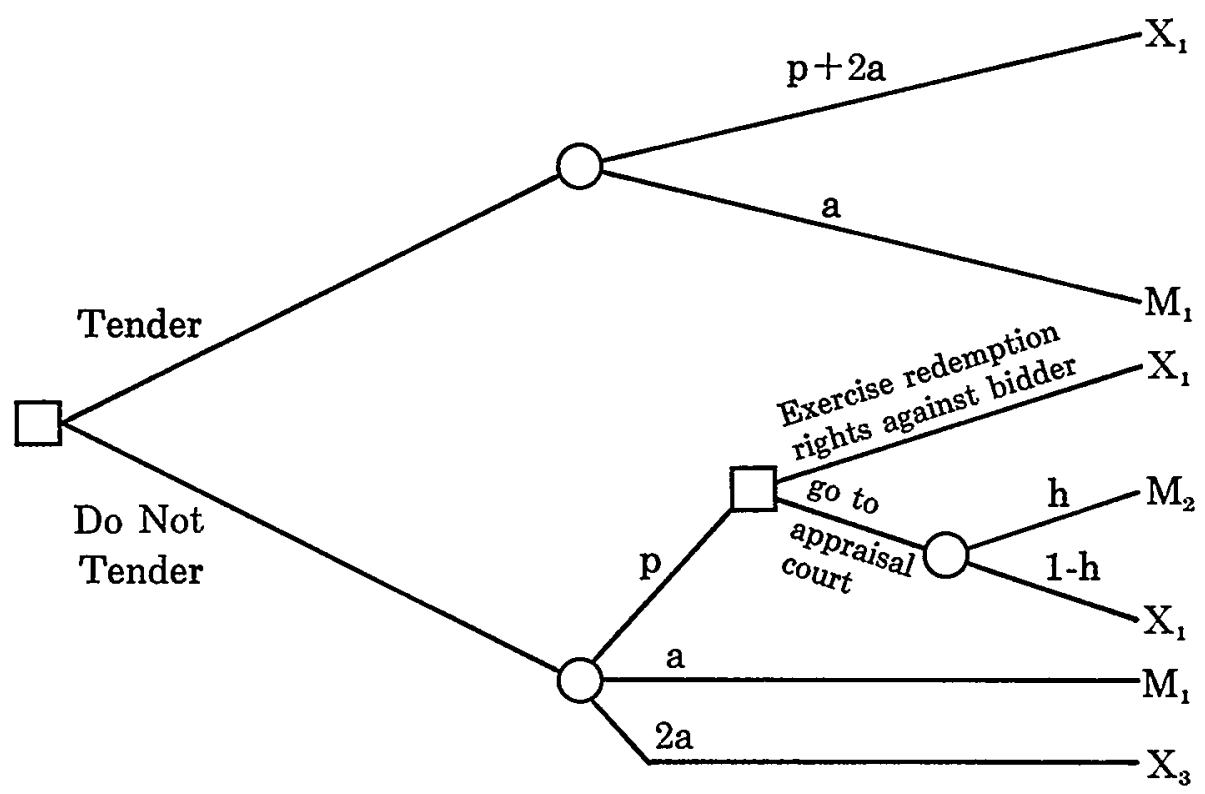

Figure 6a. Redemption rights rule and a two-tier offer.

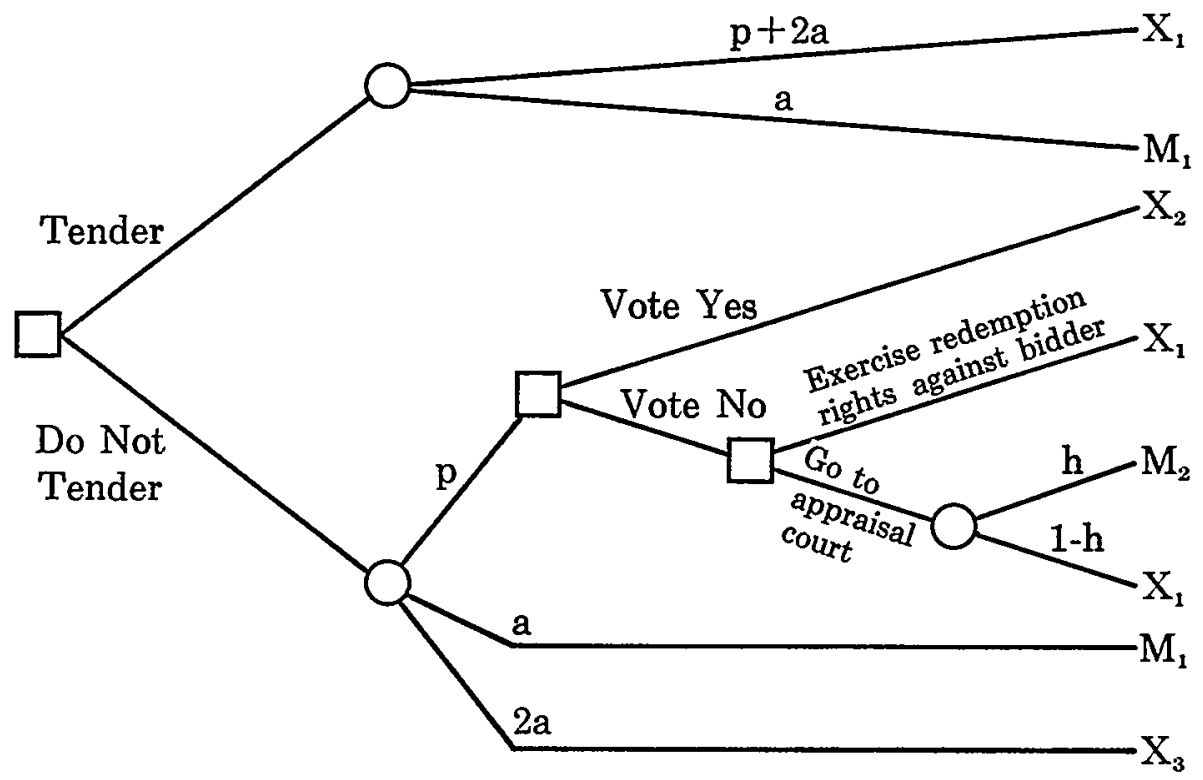

Note: The decision rule is still do not tender (shareholder always HeinOnline -- 73 Va. L. Rev. 1651987 
ability that an appraisal court may value the shares at less than $\mathrm{X}_{1}(\mathrm{~h}>0)$, the shareholder will always exercise his redemption right against the acquirer rather than go to court for an appraisal, as the statutes permit, when the maximum the court will award is $\mathrm{X}_{1}$. The provision exacerbates the inertia effect of a fair price provision on shareholder decisions: the decision choice is always do not tender. This is because the shareholder can do no worse by not tendering, and he can possibly do better because he retains the opportunity of participating in a higher subsequent offer. This is, in fact, the Grossman and Hart result.

A control share acquisition statute is similar to a supermajority provision because, as interested shares are excluded from voting on the control transaction, a smaller number of shares than a majority determine the outcome of a bid. Figures 7 and 7 a portray the decision problem for a shareholder in a firm operating under such a statute. In contrast to the other rules, under most control share

Figure 7. Decision when there is a control share acquisition rule with appraisal rights.

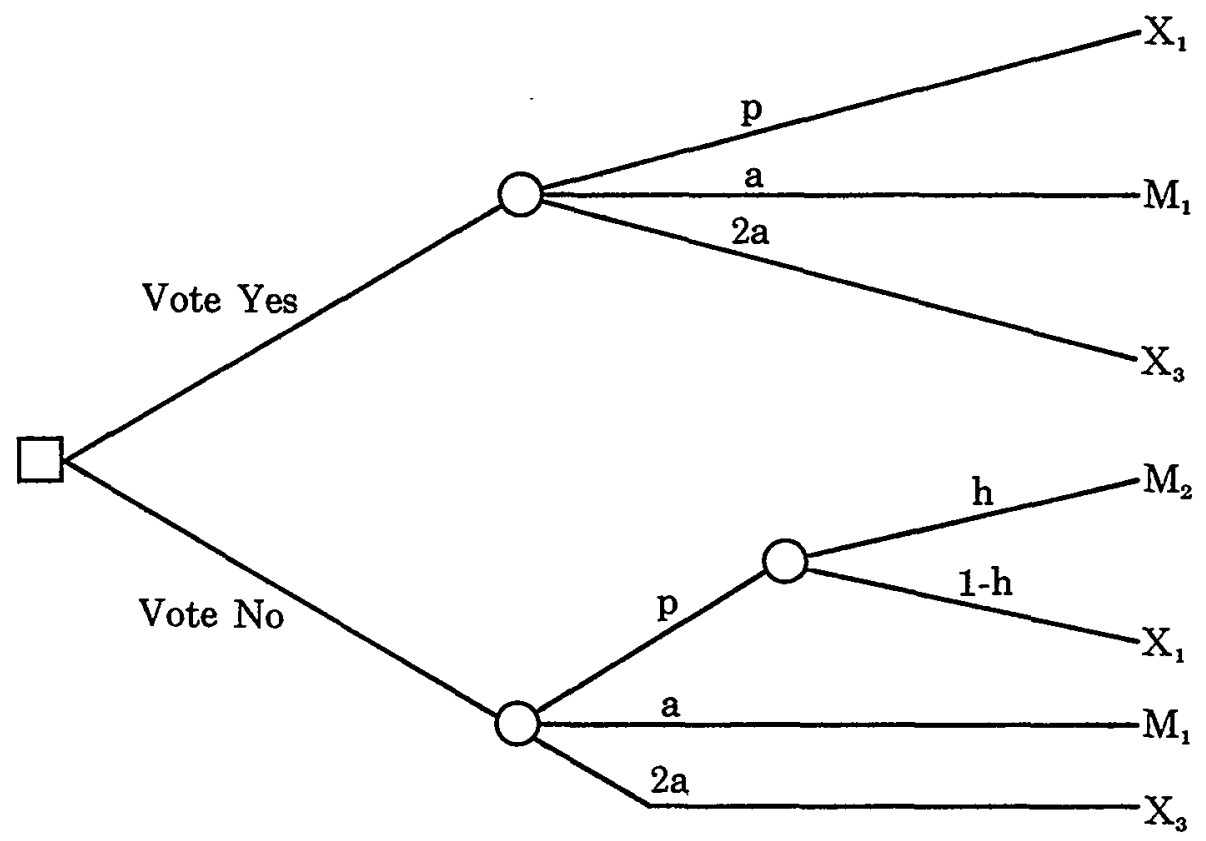


Figure 7a. Decision when there is a control share acquisition rule with no appraisal rights.

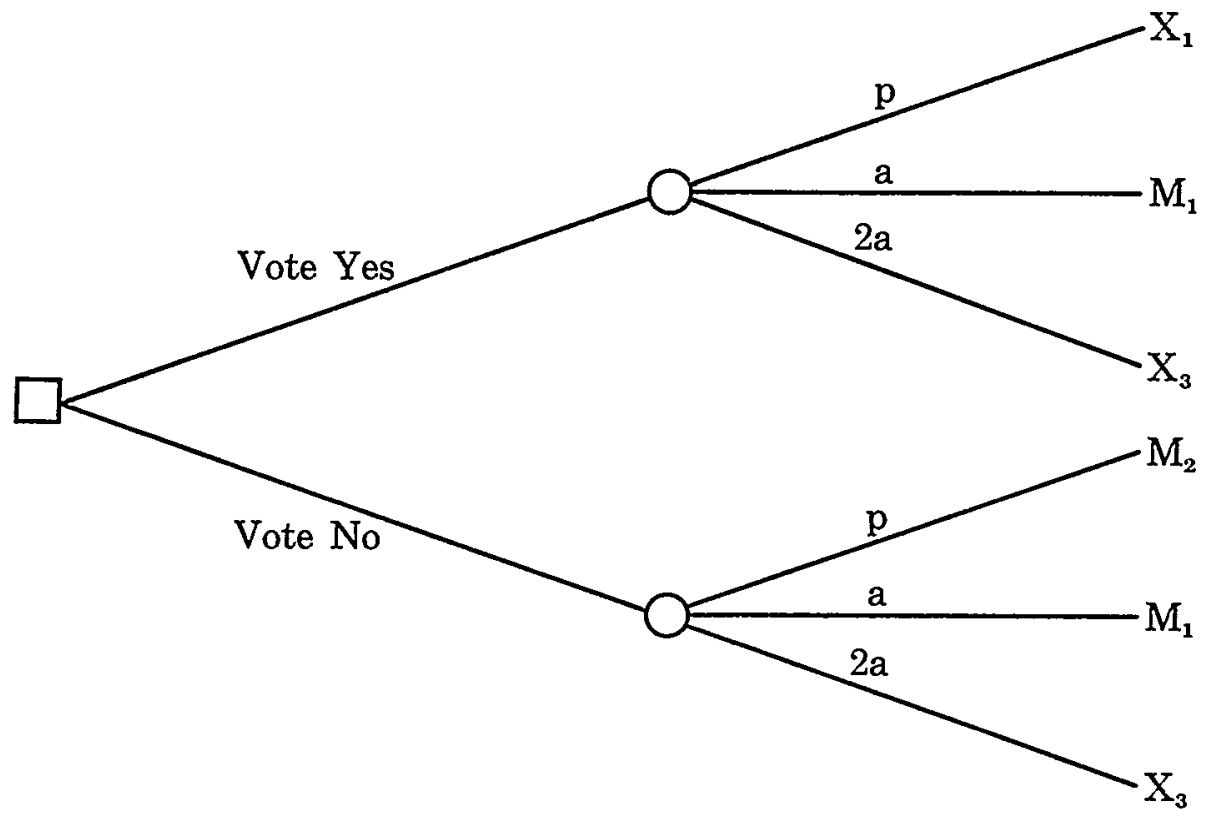

Figure 7b. Control share acquisition rule and a two-tier offer.

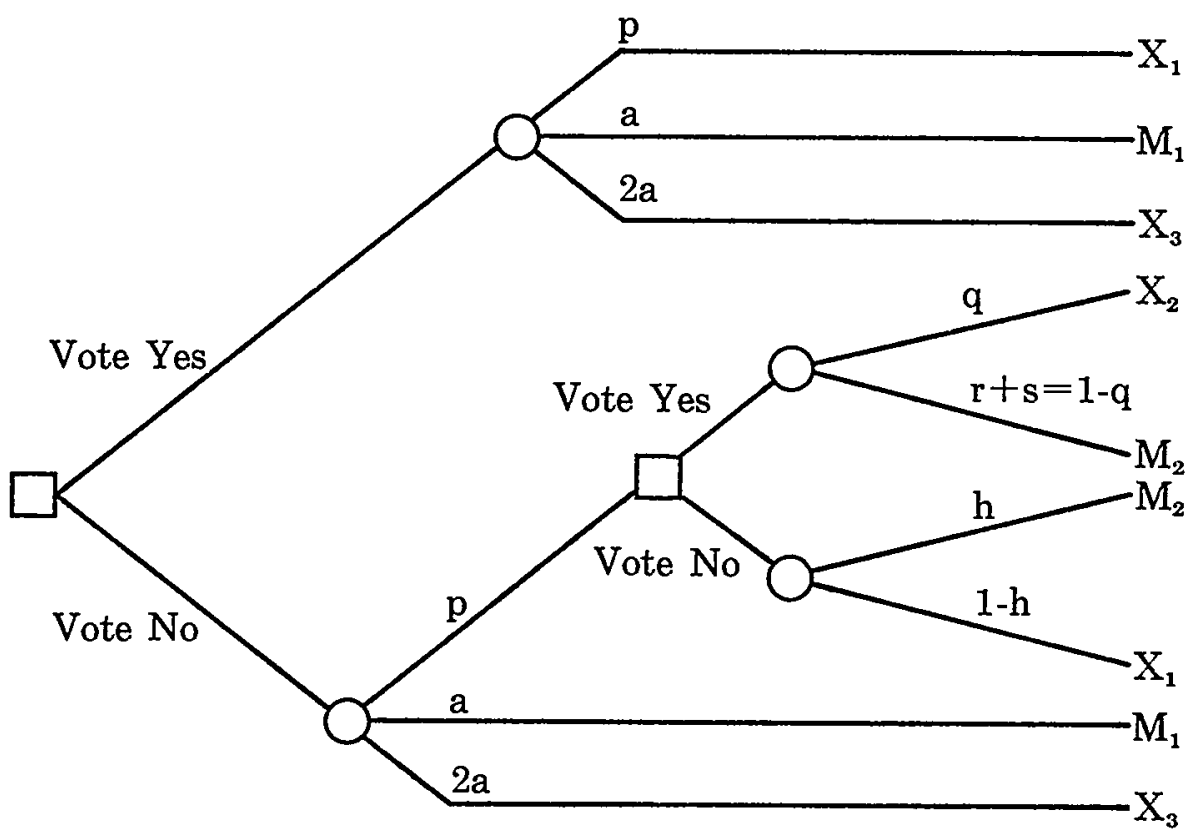

Note: The decision rule is still always vote yes. 
acquisition regimes the bidder cannot acquire the shares if the bid fails (if less than a majority of the shares votes in favor of the acquisition). ${ }^{114}$ The probabilities and payoffs of tendering are modified accordingly in offsetting ways--the probability of receiving $X_{1}$ is decreased and the possibility of receiving $X_{3}$ is introduced. In addition, appraisal rights are granted to dissenters from an approved control share acquisition only in some states. Accordingly, figure 7 represents the decision problem when appraisal rights exist and figure 7a when they do not. The decision rule is the same in the two situations. The control share acquisition provision magnifies the effects discussed in the previous section on supermajority provisions, that the shareholder tenders more frequently with such a rule than with a fair price rule. The decision is always vote yes, unless, as detailed in the appendix, the assumption concerning the appraisal court's award is altered to allow the maximum amount to be $X_{3}$, which is higher than $X_{1}$.

This decision rule is unchanged even in the case where the shareholder's decision affects the outcome (figure 8), assuming, consistent with the analysis throughout, that the relative likelihood of receiving $M_{1}$ compared to $X_{3}$ remains the same. If the probabilities are adjusted more generally by adding $n p$ to the likelihood of no subsequent bid and (1-n)p to that of receiving a subsequent bid, then the shareholder always tenders if $n>.333$. If $n<.333$, then the decision to tender depends on whether $\rho>-.0166 /(.56 n-$ .1866).

There is a significant difference between these statutes and a fair price provision, a difference that was touched upon in the discussion of supermajority clauses. Both the control share acquisition and redemption rights statutes offer no alternative options to bidders except, respectively, either to win a supermajority vote or to pay the fair redemption price, if they wish to gain control. The fair price statute, by contrast, gives the bidder more choice-it can win a supermajority vote, pay a fair price, gain management's approval, or be content with an acquisition of less than one hundred percent. In this respect, bidders might prefer a fair price regime to all others because it gives them the greatest flexibility in structur-

114 In some regimes the shares may be purchased but are stripped of voting rights; the net result will be the same: The bidder will not acquire the sbares because non-voting shares are of no value to a bidder for control. 
ing acquisitive transactions.

Figure 8. Control share acquisition rule, decision affects outcome.

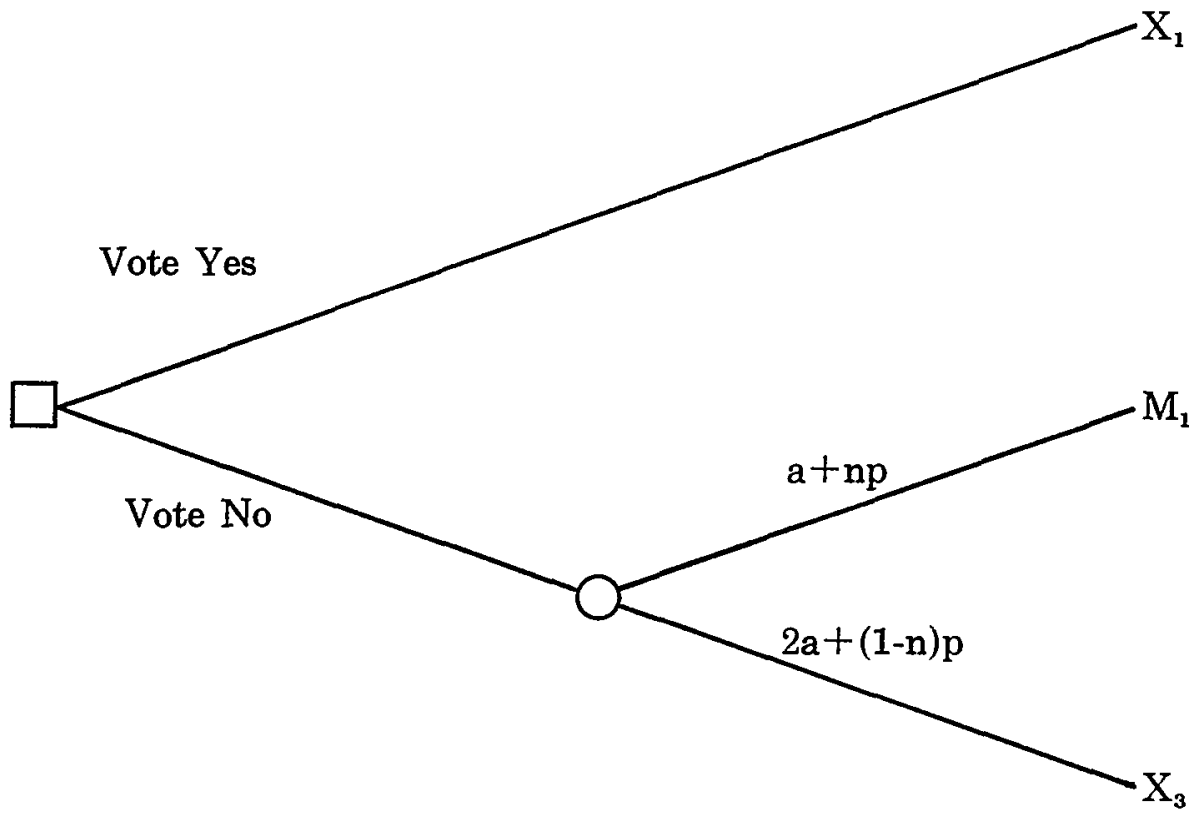

A corollary is that a fair price statute should impact less heavily on the frequency of initial bids than either of the other statutes because, by giving bidders more room in which to maneuver, it does less to discourage control changes. If so, this would probably be the most important reason for the popularity of fair price provisions in charters and with legislators. However, the decision tree analysis provides mixed support for this contention. While it implies that shareholders may tender less frequently under a redemption rights regime than a fair price regime, it also suggests the counterintuitive result that shareholders may tender more frequently under a control share acquisition statute than a fair price provision.

This describes a bidder's preference schedule among statutes as: control share acquisition, fair price, redemption rights. Qualifying the bidder's preference for a control share acquisition regime may be the fact that under most versions of the law the bidder cannot acquire any shares if the offer is rejected by the shareholders. The 
bidder can do so under the other statutes, which do not affect the current contractual basis of the purchase obligation in the case of a failed bid.

It might appear peculiar that the most popular shark repellent charter amendment and takeover statute, a fair price provision, is less restrictive of bidders' actions and thereby less likely to discourage a takeover attempt than the other defensive strategies. But the decision analysis suggests an explanation. Shareholders who vote on shark repellent amendments may be consciously concerned about the tradeoff in the frequency of initial bids against the size (or distribution) of bid premiums. Investors may be willing to sustain some decrease in the probability that their firm will be taken over in order to achieve a particular level of certainty concerning the premium they will receive: They choose the tactic that seems to have the smallest impact on the probability of a bid, while retaining some possibility of exercising the option to gamble on a higher premium. For fair price provisions encourage the shareholder to retain shares some, but not all, of the time. This explanation is at odds with the contention of Frank Easterbrook and Daniel Fischel that the ex ante decision of all shareholders would be to ban all defensive tactics so as to maximize the likelihood of takeover bids. ${ }^{115}$ The point is explored further in the next section, which examines under what conditions shareholders would voluntarily support fair price provisions.

\section{B. When Might Investors Decide to Support a Fair Price Provision?}

The analysis of shareholder decisions under fair price provisions suggests an important question: why don't all firms-and all states-adopt such a rule? I explore in this section an explanation of the variation across firms that is based upon the notion that not all shareholders will reach the same conclusion concerning fair price provisions. The key feature on which I rely is that these provisions do not affect all shareholders equally because of the techniques bidders employ to obtain control and the differences in information that shareholders possess concerning acquisitive

\footnotetext{
116 See Easterbrook \& Fischel, The Proper Role of a Target's Management in Responding to a Tender Offer, 94 Harv. L. Rev. 1161 (1981). Bebchuk also disputes Easterbrook and Fischel's thesis, on normative grounds. See Bebchuk, supra note 102, at 1784.
} 
transactions. It would, accordingly, be in the interest of some shareholders, but not all, to support a fair price amendment. ${ }^{118} \mathrm{~A}$ further implication is that the statutes may have real bite for some firms yet be uncontroversial for others, depending on the firm's ownership composition.

\section{Acquisitive Techniques and Shareholder Information Costs}

Before developing the scenario in which some shareholders desire a fair price provision, it will be helpful to introduce one of the most successful techniques for acquiring control, the three-stage offer. The sequence is as follows: a negotiated private purchase, typically for cash, of a block of stock, followed by a cash tender offer, at the same price, either for any-or-all shares or for control, and lastly, a cash merger of the target company into a subsidiary of the acquirer, giving it one hundred percent control. ${ }^{117}$ If the same price per share is paid in each of the three stages it would not matter to target shareholders at which stage they cash in their holdings. But if the price is lower in the third stage than in the second, and if not all shares are tendered in the second stage, then those who tender will receive more per share than those who give up their stock in the merger.

The negotiated purchases in the first step of the transaction are made either from a controlling shareholder if there is one, or from a large, usually institutional, noncontrolling shareholder or a collection of such investors. The purchases are typically made at a substantial premium above market with a most-favored-nation

116 $\mathrm{My}$ thesis is therefore different from Carney's prisoners' dilemma analysis, for it does not distinguish among shareholders in the evaluation of the desirability of shark repellent devices. See Carney, supra note 100 . In a recent article, Carney refines his position. While his analysis of shareholder decisions is unchanged, he also maintains, as I do in this article, that institutional and individual investors will disagree on shark repellent amendments. See Carney, Two-Tier Tender Offers and Shark Repellents, 4 Midland Corp. Fin. J. 48, 53 (1986). My analysis is also distinct from Bebchuk's; although he emphasizes the differential effect of acquisitions on different types of shareholders, he advocates one rule for all firms, which differs from the provisions that firms voluntarily adopt. See Bebchuk, supra note 102, at 1244-52. Moreover, my explanation of shark repellent amendments is contrary to Gilson's critique of these provisions. I suggest that shareholders can benefit from fair price proposals precisely because they enable investors to realize information-cost savings. Cf. Gilson, supra note 89.

117 Freund \& Easton, The Three-Piece Suitor: An Alternative Approach to Negotiated Corporate Acquisitions, 34 Bus. Law. 1679, 1683-84 (1979). 
clause in the contract, by which the purchaser promises to pay the seller the highest price it pays to any subsequent seller in the first or second step. ${ }^{118}$ Bidders frequently resort to this tactic because the nonpublic purchases in the first step facilitate a control change by enabling the bidder to gain a leg up on potential competitors, including incumbent management. This technique suggests the linchpin for my explanation of the choice of adopting a fair price provision: because of their position, institutions or individuals with large blocks of stock rarely miss out on a premium. Not only are these investors often approached in the early stages of an acquisition, which gives them access to nonpublic information concerning bids, but also, because there are economies of scale in obtaining information-the fixed costs are spread over more shares-they will engage in their own efforts at generating information on the

${ }^{118}$ A well-known use of this technique was Sun Company's attempt to acquire Becton Dickinson Corporation. The facts are detailed in Wellman v. Dickinson, 475 F. Supp. 783, 805-11 (S.D.N.Y. 1979), aff'd, 682 F.2d 355 (2d Cir. 1982), cert. denied, 460 U.S. 1069 (1983). Sun solicited 30 institutions with an offer of either a top final price of $\$ 45$ per share or a price of $\$ 40$ with a most-favored-nation guarantee. The solicitation was conditioned on Sun's obtaining $20 \%$ of Becton's stock and was undertaken after the stock exchange had closed for the day. The institutions were asked to respond within an hour, though some were given until the following day. The idea was to accumulate a suhstantial block of stock before the market reopened to ensure a successful public takeover. Sun obtained over $30 \%$ of Becton's shares by this method.

I cite this case only as a sharp illustration of the technique. Sun's activities were found to have violated the Williams Act. The purchases were held to constitute a tender offer, and therefore, Sun had to comply with the Act in order for the offer to proceed. Id. at 817-26. The technique has not been questioned for smaller accumulations. The important point is that it demonstrates a key transactional feature for a successful bid: the pivotal, initial role of institutional investors and individuals with large blocks of stock.

Recent events continue to bolster this point. Campeau Corporation, for instance, was able to acquire control of Allied Stores by privately purchasing a block of shares assembled by Jefferies \& Company after Campeau withdrew a public tender offer. Judge to Rule on Acquisition of Allied Stake, Wall St. J., Oct. 27, 1986, at 3, col. 1. In addition, the insidertrading scandal involving arbitrageur Ivan Boesky, see Spreading Scandal: Fall of Ivan Boesky Leads to Broader Probe of Inside Information, Wall St. J., Nov. 17, 1986, at 1, col. 6, suggests further techniques that aggravate information disparities between institutions and individual and large and small investors. Investment banks appear to have aided acquiring firms, as well as themselves, by tipping selected arbitrageurs on impending bids so that blocks of stock would be in friendly hands. The practice may well be widespread. Not only have the information-equalizing Williams Act 13D filing requirements that disclose $5 \%$ interests been circumvented by the practice, but the Hart-Scott-Rodino Act's premerger notification requirements have also been evaded as investment banks have purchased and held shares for bidders, thereby avoiding the need for compliance on the ground that the direct owner of the shares has investment, and not merger, as its purpose. See Takeovers Scrutinized by FTC, N.Y. Times, Dec. 24, 1986, at D1, col. 6. 
outcomes of bids and will be better informed than investors with smaller holdings. ${ }^{119}$

These factors suggest that the most obvious impact of a fair price requirement is its function as a small shareholder protection provision. Common wisdom has it that such shareholders are less likely to tender their shares than larger and more sophisticated investors. In addition, small shareholders are not approached by a bidder who seeks to accumulate a block before it makes a public offer, nor are they contacted directly during the bid. Accordingly, they are more likely to be the ones who are cashed out in the final merger stage of an acquisition. One does not have to attribute irrationality or idiosyncratic valuation of shares as the reason for the failure of small shareholders to tender, but rather, greater costs in obtaining information about the transaction. Moreover, not all of the larger investors' private information will be impounded in the stock price during the bid in time to be of use to smaller shareholders, because most institutions tender just as the bid is about to expire. ${ }^{120}$ In this scenario, a fair price provision is a mechanism for equalizing information, and thereby the price received, across shareholders.

\section{A fair price provision can be characterized as a device for enforc-}

110 For instance, if not all shareholders know that the merger price will be less than the tender price, some may not tender. As a consequence, the tendered shares will receive more than their pro rata share of the premium, even in a partial offer that is oversubscribed. Institutions that are sophisticated repeat players, and are often contacted by tenderors during the public offer period if they are not approached initially in the private purchase stage, are knowledgeable about the typical terms of acquisitions, the likelihood of success, and the possible differential between tender and merger prices.

${ }^{220}$ This is another instance where transaction costs and economies of scale matter. Institutions can wait until the last minute to tender their shares. Last minute tenders are expensive because special messengers must be used to ensure the timely delivery of the shares or guaranteed delivery and transmittal letters. Most small individual shareholders or stock retailers cannot afford to follow such a strategy and, as a result, they tender earlier on in the bid. If it looks like a higher bid will be forthcoming when the bid expires, larger shareholders and institutions are more hikely to retain their shares and participate in that later offer than smaller shareholders.

Small shareholders could sell in the market at the last possible minute rather than tender, and thereby obtain more information, as revealed in the market price, concerning the bid. But even without data as to whether they follow such a strategy, there are several obvious disadvantages: The stock market closes many hours before a bid typically expires, thus limiting how much information will be revealed, and the price received by selling will be less than the price received by tendering. 
ing the rule prohibiting the payment of a non-pro rata dividend ${ }^{121}$ in the context of a liquidating distribution of the proceeds of a takeover, but the logic or desirability of the provision has to do with information costs. A fair price rule reduces information costs for small shareholders because they need not become informed about the terms of the deal to guarantee that they receive the best price that informed shareholders obtain. On the other side, large shareholders who are most likely to tender into two-tier bids and obtain a disproportionate share of the premium would be the least predisposed to favor a fair price rule. They benefit from the disproportionate distribution of the premium and consequently, any negative effect the provision might have on bid frequency will dominate their decision. Of course, the reason why these investors receive a higher premium is precisely because not all of the other shareholders tender.

The decision tree diagrams can provide some further insight into who benefits from fair price provisions. For example, the decision tree in which the shareholder's vote affects the outcome (figure 3 ) can be interpreted as the decision of a large shareholder or informed institutional investors who as a group have a large block of stock, for in these cases it is likely that the way the investor acts will determine the outcome. That is part of the source of the informational advantage: bidders are anxious to contact investors with a block of stock because their support is crucial for the success of the bid.

The analysis indicates that when the optimal decision for the merger is to vote yes, the shareholder's decision is unchanged by the insertion of a fair price rule. This means that large shareholders will tender more frequently than small shareholders when 1 $.86 \mathrm{q}-.59 \mathrm{r}-\mathrm{s}<.14$. When the optimal merger decision is to vote no, these shareholders tender more frequently with the fair price rule than without it when $r+n q>h$, that is, when the probability of the bidder taking no action exceeds the probability of an appraisal court adopting the low valuation. In comparison to small

${ }^{121}$ See cases collected in V. Brudney \& M. Chirelstein, Corporate Finance: Cases and Materials 416-35 (2d ed. 1980). Although Unocal Corp. v. Mesa Petroleum Co., 493 A.2d 946 (Del. 1985), appears to undermine the longstanding pro rata dividend rule, the court did not view the issue as one of distribution policy and characterized it as a defensive tactic, treating Mesa in its status as bidder and not as a target sharebolder. 
shareholders, when the merger vote is no, large shareholders would tender more frequently than small ones if $n>h$ (the proportionate effect of the shareholder's action on the no merger outcome is greater than the probability of an appraisal court adopting the low valuation). Because small shareholders are unlikely to seek appraisal rights since the cost of using the procedure will be spread over only a small number of shares, $h$ is close to $1\left(M_{2}\right.$ is what the shareholder receives if he does not go to court). Yet $n$ might not be close to 1 even if the large shareholder has a sizeable block because $\mathrm{n}$ measures the bidder's reaction to the shareholders' vote. (The larger $\mathrm{n}$ is, the less likely the bidder pays the fair price.) Thus, it seems probable that $n<h$, and small shareholders tender more often than large ones in the presence of a fair price rule. In this regard, the rule helps the small investor by making it more likely that he will receive the higher premium at the front-end of the acquisition, although it is also true that the nontendering larger investors hope to receive that same price at the second step, while retaining the opportunity to receive the higher $\mathrm{X}_{3}$ if the bid fails. This analysis suggests a potentially strong equalizing effect of the rule. It also indicates under what circumstances large shareholders are indifferent to, or do not gain from, a fair price provision.

In addition, we can view the decision of a shareholder confronted with the truncated decision tree of only node 2 of figure 2 as depicting the extreme case of an uninformed shareholder's decision. This is a shareholder who did not have the chance to decide whether or not to tender and thus to give up $\mathrm{X}_{1}$ consciously in the hope of receiving $X_{3} \cdot{ }^{122}$ Such a shareholder can receive $X_{1}$ only when a fair price rule is in place; otherwise the maximum he can receive is $\mathrm{X}_{2}$. The welfare of this individual can be improved by the addition of a fair price provision under the following conditions. When the shareholder votes yes, if $2.9 \mathrm{r}<1-\mathrm{q}$, or when the shareholder votes no, if $\mathrm{h}>\mathrm{r}+\mathrm{qh}$ (the probability of receiving $M_{2}$ is greater without than with the rule), the expected value of

122 The most common and plausible explanations for untendered shares are that the owners (1) are away on vacation and either do not learn of the bid or cannot tender their shares in time; (2) do not know they own the stock; (3) are deceased; or (4) do not understand the transmittal letter and do not have a broker or lawyer who can explain it to them. Small shareholders are most likely to fit in these categories. For example, given the size of their holdings, the costs of remedying the situation in (1) or (4) may well outweigh the value of the premium they would receive for their shares. 
what the shareholder receives under a fair price rule is greater than the expected value without the rule. Hence, shareholders who are not informed about a tender, or, to put it another way, those for whom it would be costly to tender, benefit from a fair price rule under these conditions.

\section{Ownership Composition and Fair Price Provisions}

The differential distribution of acquisition premiums among shareholders and the offsetting effects of fair price provisions suggest that the likelihood that a firm will voluntarily adopt a fair price provision is affected by the composition of the firm's shareholders, for shareholders who have differing access to information on bids have different interests with respect to these provisions. The significant feature for analysis is the concentration of stock ownership, because concentration measures how the voting population is distributed, and accordingly, whether a fair price provision would be easily adopted.

Barry Baysinger and Henry Butler have also recently offered an explanation for why some firms adopt shark repellent amendments and others do not. ${ }^{123}$ They stress established relations with management, and not information costs, as the source of heterogeneity in shareholders' interests leading to the differential pattern of charter provisions across firms. The shareholders who they assert to be the advocates of shark repellent amendments are not, however, the beneficiaries among investors indicated by my analysis, or by the available data. ${ }^{124}$ The reason for the analytical discrepancy is that their analysis does not look at the content and operation of shark repellent amendments, and in particular, that of the most popular provision, a fair price rule. They focus instead on one potential result of such provisions, that a takeover's success can be thwarted. Taking the substance of the amendments into account weakens the plausibility of their story even more than the notion that shares of stock have idiosyncratic value to investors. Insiders-shareholders with established relations with management-do not clearly benefit from the most common amendment, a fair price

\footnotetext{
${ }^{123}$ See Baysinger \& Butler, Antitakeover Amendments, Managerial Entrenchment, and the Contractual Theory of the Corporation, 71 Va. L. Rev. 1257 (1985).

${ }^{234}$ See supra note 89 , discussing institutional investor voting patterns on shark repellent amendments.
} 
provision, compared to other types of tactics such as a plain supermajority rule. Rather, small shareholders with no special relation to the firm are the beneficiaries of these provisions.

The perspective of each type of shareholder, classified by holding size as a fairly accurate proxy for access to information and likelihood of participation in a bid premium, can be simply outlined. Small shareholders, who benefit most from a fair price rule, will typically favor such a rule but will succeed in enacting one only in the context of a specific constellation of stock ownership. Owners of blocks of stock who are not managers will have little interest in fair price provisions because they are likely to receive a premium for their shares, and their gain is, in fact, higher if the acquirer's payment is non-pro rata. If the large shareholder is a manager, then the supermajority component of a fair price rule may be of greater value: if the bidder cannot pay the fair price, the manager-shareholder might be able to veto a merger with the votes of his own shares and thereby retain control. ${ }^{125}$

To the extent that fair price provisions lessen the risk of adopting the strategy of not tendering in order to receive a better offer, then even these larger shareholders could benefit from such a provision. However, as the decision tree analysis suggests, fair price provisions often have no impact on large shareholders' decisions, a factor that might lead at best to indifference rather than opposition or support. The position of medium-scale investors on fair price provisions is ambiguous, because a shareholder's position is determined in relation to the holdings of the firm's other investors. The medium shareholder's information may enable him to gain a bigger premium than smaller shareholders receive, but he would be in the opposite position when the comparison is with larger shareholders.

Although shareholders clearly possess different information when it comes to actual bids, when they vote on shark repellent charter amendments there is no reason to assume that an informational disadvantage persists. Knowing the general direction of the

\footnotetext{
125 Of course, these shareholders might well prefer a plain supermajority provision. Years ago, shark repellent amendments were of that variety and did not include any means by which the bidder could avoid a supermajority vote. Today, however, such provisions are less in fashion than fair price clauses. It may be that a fair price option must he attached to a supermajority voting rule for manager-shareholders to gain the support of enough other shareholders to amend the corporation's charter.
} 
effects of fair price provisions on bid premium and frequency, as well as knowing that differences in information on bids exist across shareholders, is equivalent to knowing the rules of the game, ${ }^{126}$ whereas knowledge about the specific terms of transactions and the likelihood of a competing offer is more akin to inside information, which is created by positional advantages. It is typically assumed that all players know the rules of the game, and it is realistic to maintain the assumption in this context, given the publicity that surrounds shark repellent amendments. Moreover, the most generally accepted interpretation of stock market efficiency, that prices reveal all publicly available information but not inside information, supports this assumption by indicating what type of information small shareholders can extract from stock prices.

One would accordingly expect that firms with several owners of relatively large blocks of stock-ownership concentration in the middle to high range-would not voluntarily adopt a fair price provision. Firms that have a large number of small shareholders and a few medium or large investors-low ownership concentration-would be prime candidates for a successful charter amendment, because a majority of the shares would be owned by the class that benefits from a fair price rule. If the firm has a middle to high degree of concentration, then even though there are small shareholders who favor a fair price rule, they may not own enough shares to be able to enact one. Finally, when there are numerous medium sized investors and the concentration of ownership is in the low to middle range, the voting outcome is ambiguous because if medium sized investors are indifferent, some may join the small shareholders and vote in favor of management's proposal, and the amendment could pass. Table two plots a shareholder's perspective toward a fair price provision against the firm's ownership concentration using the classification of small, medium, and large shareholders and low, middle, and high concentration. ${ }^{127}$

${ }^{126}$ The fact that information asymmetries exist is often included in the common knowledge of the rules of the game.

${ }^{127}$ I would like to thank Oliver Williamson for suggesting this table to me. 
Table two. Shareholder attitudes towards a fair price provision.

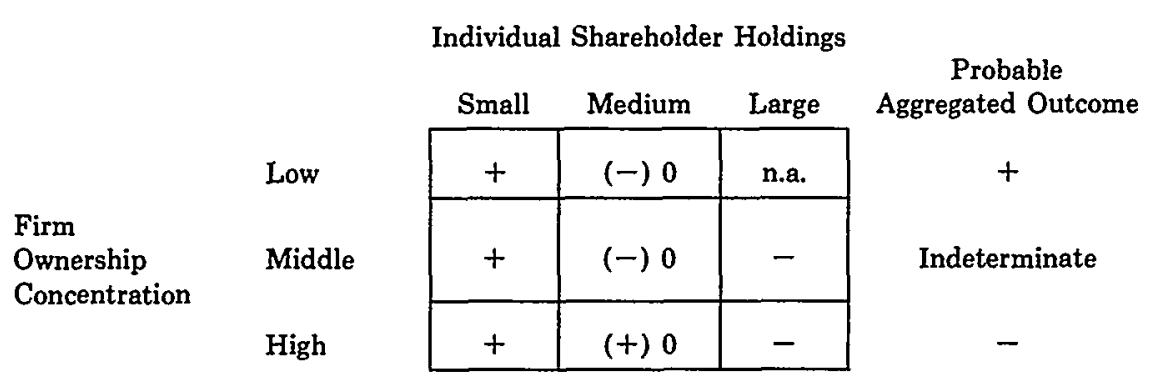

Note:

$+=$ shareholder supports fair price rule

$-=$ shareholder opposes fair price rule

0 = shareholder indifferent to fair price rule

To test this thesis, I used a simple concentration measure for the firms in my sample, which is the ratio of the number of common shares outstanding to the number of shareholders of record. ${ }^{128} \mathrm{I}$ then performed several statistical tests to determine whether the concentration ratios differed systematically for firms with and without fair price provisions. The results are ambiguous. The concentration ratios differed systematically across states, although the existence of fair price provisions did not: The average concentration of firms in states with second generation statutes was statistically siguificantly lower than that of firms in states without these statutes. I therefore evaluated the concentration data separately for the two groups. For the group in states with a statute, the firms with fair price provisions had lower concentration ratios, as anticipated, but the difference was not statistically significant. For the group in states without a statute, the firms with fair price provisions had higher concentration ratios, but again, the difference was not statistically significant. ${ }^{129}$

${ }^{128}$ The ownership data was obtained from Standard \& Poor's New York Stock Exchange Stock Price Reports. For firms with fair price provisions, I used the information for the date the provision was adopted; for the remaining firms, if they were incorporated in a state with a second generation statute, I used the date when the statute was adopted, and if they were in a state with no statute, I used mid-1985 data, the latest time period for which I had obtained information on the content of charters. Because the reports provide stockholder information only after 1978, firms that had adopted fair price provisions before that year had to be excluded from the analysis.

128 Because the firms without fair price provisions greatly outnumber the firms with fair price provisions, I also compared the mean concentration ratios of a random set of firms in 
There is one other factor of interest that can aid in interpreting the results. Concentration ratios and the percent of shares owned by insiders are positively correlated in the sample, and no firms with fair price provisions have an insider holding more than fifty percent of the stock. I found that inside ownership differed significantly across firms, with fair price firms having lower percentages. The data is in keeping with the research of Cindy Alexander, who found that the relationship between insiders' shares and supermajority voting rules is nonlinear. ${ }^{130}$ The thesis is that up to around twenty percent ownership, insiders will favor such provisions to obtain veto power, but as their ownership share increases beyond that range they no longer desire a supermajority rule because it could hinder their exercise of control. Because the veto motive is unrelated to the concerns of non-management shareholders who are considering fair price proposals, I reevaluated my data excluding from the sample firms that had insiders with more than twenty percent ownership. I found that in this subsample, firms with fair price provisions had lower concentration ratios in states with statutes, but the difference was not significant.

\section{A Final Word on When Statutes Are Desirable}

The ownership-concentration thesis has implications for the essential question concerning second generation takeover statutes. If a firm could voluntarily adopt a fair price provision because a majority of the shareholders would benefit from a pro rata distribution rule, then to have the provision included in its charter by stat-

which the numher of firms with and without provisions was equal. In this sample, the lower concentration ratio of firms in states with statutes was not statistically significant, and for the aggregate group of firms, firms with fair price provisions had lower concentration ratios, as expected, but again this difference was not significant. I compared the firms grouped by state and found that in this sample, the results were the opposite of the more inclusive sample: firms with fair price provisions had lower concentrations in states without statutes and had higher concentrations in states with statutes than firms with no provisions. In both cases the differences were, as before, insignificant.

130 See C. Alexander, Ownership Structure, Efficiency, Managerial Entrenchment, and Antitakeover Charter Amendments 10-12 (1985) (copy on file with the Virginia Law Review Association). My data duplicated her finding of nonhinearity; in a probit regression, with the dichotomous dependent variable the choice of a fair price provision, the coefficients of the independent variables of percent insider ownership and percent insider ownership squared were respectively, positive and negative, and the asymptotic t-statistics for botll were statistically significant at the five percent level. 
ute rather than by the shareholders' vote poses no serious problem given the conventional goal of corporation law. This does not mean that management's support of a fair price provision is a selfless act. Rather, it simply suggests that management's desire to preserve its position by discouraging two-tier offers does not conflict with a majority of the shareholders' wishes. In these cases, a reasonable characterization is that the statute reduces the firm's transaction costs by eliminating the need for a shareholder vote. The finding that firms in states with statutes have lower concentration ratios tends to support this transaction cost-reducing view of the legislation, because these firms' shareholders would approve such provisions.

The obvious problem created by the statutes is that management may be able to circumvent a negative shareholder vote by lobbying the state legislature. I suspect that the corporations most active in the enactment of antitakeover legislation are those whose ownership patterns would make it difficult to adopt a charter provision. Aetna is illustrative of the problem. Aetna has no shareholder who owns at least five percent, although it has a substantial number of institutional investors. Its ownership concentration, however, is in the high range: its concentration ratio was in the top quartile of firms in my sample no matter how I grouped firms-in aggregate, in states with statutes, or in Connecticut alone. It therefore falls in the set of firms for which the voluntary adoption of a fair price amendment by shareholder vote could be difficult. ${ }^{131} \mathrm{Al}-$ though this is not conclusive evidence, it is suggestive of a managerialist explanation of the legislation.

Better evidence of whether shareholders or managers benefit from these statutes can be produced from an event study, which uses conventional financial econometric techniques to measure the impact on firms' stock prices of discrete events-changes in the information set about firms from which price expectations are formed. ${ }^{132}$ If second generation takeover statutes benefit shareholders, we should see a positive effect on stock prices when inves-

131 The concentration ratio for the firm that was said to be behind Pennsylvania's redemption rights statute is, however, well below the average concentration ratio of firms in my sample, even though it has a $24 \%$ shareholder.

${ }^{132}$ For a summary and assessment of the methodology see Brown \& Warner, Using Daily Stock Returns: The Case of Event Studies, 14 J. Fin. Econ. 3 (1985). 
tors learn of their enactment, and conversely, if shareholders are harmed, we should find a negative effect. I undertook such a study for three of the statutes: Connecticut's fair price statute, Missouri's control share acquisition statute, and Pennsylvania's redemption rights statute.

One of the difficulties for an event study involving statutes is in identifying which of several dates, such as the date of a bill's introduction or of its approval by the legislature, is the day on which investors became informed about the law. The power of the methodology depends on accuracy in pinpointing the announcement dates defining events. The technique assumes an efficient stock market-investors' evaluation of a statute's impact on firms' future cash flows is reflected in stock prices as soon as they become informed about the law-and if the wrong date is chosen the impact will not be isolated. The complication with a statute is that the enactment date may be too late because investors may have already learned about the legislation and assessed its likelihood of passage, but the earlier introduction date may be an inaccurate announcement date because bill introductions typically are not publicized. These limitations are not as troublesome as would appear for the second generation takeover statutes because they have a relatively short time span between introduction and approval-on average, one month-and because they are virtually always enacted, so the amount of uncertainty that would have to be resolved over an interval is lessened. The three statutes I examine were chosen as exemplars of the three statutory patterns because they had the shortest time spans from introduction to enactment.

Portfolios were formed of the NYSE companies incorporated in each of the three states. The portfohios were also subdivided into firms that had fair price provisions in their charters before their state's second generation takeover statute was enacted and firms that did not. ${ }^{133}$ In addition, for Pennsylvania, a third portfolio was

${ }^{139} \mathrm{My}$ reasons for examining the sinaller portfohos as well as the aggregate portfolios are as follows: Because not all firms are potential targets, not all firms could be expected to experience abnormal returns upon the enactment of the legislation. Accordingly, the aggregate portfolio might hide the impact of the legislation on the unidentifiable subset of future target firms. Firms with shark repellent amendments may be more likely to be targets, compared with other firms, and thus it might be useful to contrast the market reactions of the separate portfolios. But there is a complicating offsetting factor: these firms may also gain (or lose) less from the statute than defenseless firms because the benefit or detriment of 
formed consisting of the firms that had opted out of the redemption rights statute's coverage. Market-model regressions ${ }^{134}$ were run for each of the portfolios. Two dates were used as the event date-the date the bill was introduced ${ }^{135}$ and the date the state senate approved the bill-and accordingly two regressions were run for each portfolio. An event study for the Pennsylvania firms that had opted out of the redemption rights statute was also performed, in which opting out is the event under examination.

There were no significant effects of the statutes on stock prices in any of the regressions. The portfolio average residuals on or shortly after the event dates, which pick up any abnormal returns that can be attributed to the event, were statistically insignificant in all of the regressions. Table three shows the values of the tstatistics for the average residuals on the event day, the day before

their self-help measures would already be reflected in their stock price. In addition, the firms that opted out of Pennsylvania's statute might have been qualitatively different from other firms and presumably would be expected to have been negatively affected by the statute.

In assessing the findings concerning these various subportfolios, a further caveat is in order. The subdivided portfolios, as well as the aggregate Connecticut and Missouri portfolios, are small by conventional standards-less than 20 firms-and the power of the methodology depends on having an ample-sized portfolio. To increase the size and hence the power of the tests, I also formed portfolios that included American Stock Exchange (ASE) firms. But because I was unable to obtain charter information on all of the ASE firms, I could only examine the effects on aggregate portfolios. As the results did not differ significantly from the regressions using only NYSE firms, tables 3 and 4 report only the results of that group, because it could be subdivided.

135 The market model is estimated using the following procedure: $A_{i t}=R_{i t}-\alpha_{i}-$ $\beta_{i} R_{m t}$ where $A_{i t}$ measures the abnormal return on stock $i$ at day $t, R_{i t}$ is the return on stock $i$ at day $t, R_{m t}$ is the return on the market portfoho at day $t$, and $\alpha_{i}$ and $\beta_{\mathfrak{i}}$ are ordinary least squares values from the estimation period, whicb is day -365 through day -11 . To undertake significance tests, the residuals are averaged across all the stocks in the portfolio. See Brown \& Warner, supra note 132.

1ss For Missouri, I used the date the bill was reported out of committee, because the bill had been prefiled at the end of the previous session as well as revised by the committee. It would be plausible to assume that investors would not have deemed significant any information concerning the initial filing of the bill. Only the Pennsylvania statute's progress was reported in the Wall Street Journal, see, e.g., Pennsylvania Bill on Dissident Stakes Clears Legislature, Wall St. J., Dec. 15, 1983, at 42, col. 1; Pennsylvania Senate Is Seen Near Vote on Bill that May Deter Dissident Investors, Wall St. J., Dec. 6, 1983, at 12, col. 1. The date of the first Wall Street Journal article on Pennsylvania's statute was also used as an event date; it produced results indistinguishable from those centered on the later date, which are reported in tables 3 and 4. The lack of press coverage of the Connecticut and Missouri legislation may limit the ability to attribute to investors knowledge of tbose statutes upon the introduction and approval dates. 
it, and the day after it, for each portfolio. ${ }^{136}$

Table three. T-statistic values for average residuals.

Early Announcement Dates:

$\begin{array}{lrrr}\text { Portfolio [size] } & \text { Day -1 } & \text { Day 0 } & \text { Day }+1 \\ \text { Connecticut } & & & -0.7111 \\ \text { all [18] } & -0.1742 & 0.6482 & -0.7603 \\ \text { no fp [12] } & -0.2311 & 0.6895 & -0.1932 \\ \text { fp [6] } & 0.0309 & 0.1824 & \\ & & & 0.1746 \\ \text { Missouri } & & & 0.2083 \\ \text { all [14] } & -1.0731 & -0.3513 & -0.0006 \\ \text { no fp [9] } & -1.3199 & -0.0026 & \\ \text { fp [5] } & 0.0815 & -0.8087 & \\ & & & 0.2582 \\ \text { Pennsylvania } & & & 0.2871 \\ \text { all [53] } & 1.2801 & 0.9503 & -0.0036 \\ \text { no fp \& opt-out [47] } & 1.1744 & 0.7966 & 0.4016 \\ \text { no fp [38] } & 1.2338 & 0.6394 & -0.0908 \\ \text { opt out [9] } & 0.4108 & 0.5907 & 0.8820 \\ \text { fp [6] } & 0.7689 & & \end{array}$

Late Announcement Dates:

\begin{tabular}{|c|c|c|c|}
\hline Portfolio [size] & $D a y-1$ & Day 0 & Day +1 \\
\hline \multicolumn{4}{|l|}{ Connecticut } \\
\hline all [18] & -0.4295 & -1.0620 & 0.3316 \\
\hline no $f p[12]$ & -0.6515 & -0.4659 & 0.5661 \\
\hline $\mathrm{fp}[6]$ & 0.2428 & -1.4755 & -0.3020 \\
\hline \multicolumn{4}{|l|}{ Missouri } \\
\hline all [14] & -1.7464 & 0.1448 & 1.1779 \\
\hline no fp $[9]$ & -1.0220 & 0.3081 & 0.7068 \\
\hline$f p[5]$ & -1.2923 & 0.7282 & 2.1440 \\
\hline \multicolumn{4}{|l|}{ Pennsylvania } \\
\hline all $[53]$ & -0.5675 & -0.3147 & 0.3645 \\
\hline no fp \& opt-out [47] & -0.5926 & -0.4980 & 0.1289 \\
\hline no fp $[38]$ & 0.1012 & -0.6702 & -0.8399 \\
\hline opt out [9] & 0.5030 & -1.0386 & 0.2166 \\
\hline fp [6] & 0.6353 & -0.3379 & 0.4279 \\
\hline
\end{tabular}

130 The t-statistic values for the average residuals of the portfolio of firms opting out of the Pennsylvania statute in the opting-out event study were:

$\begin{array}{lrr}\text { day } & -1 & 1.5024 \\ \text { day } & 0 & 0.0010 \\ \text { day } & +1 & -1.5937\end{array}$


Table four. Cumulative average residuals.

Early Announcement Dates:

\begin{tabular}{|c|c|c|c|c|c|}
\hline Portf. [size] & -10 to +60 & -1 to +1 & (t-statistic) & -5 to +5 & (t-statistic) \\
\hline $\begin{array}{l}\text { Connecticut } \\
\text { all [18] } \\
\text { no fp [12] } \\
\text { fp [6] }\end{array}$ & $\begin{array}{l}-0.0342 \\
-0.0274 \\
-0.0480\end{array}$ & $\begin{array}{r}.0001 \\
-.0002 \\
.0008\end{array}$ & $\begin{array}{r}(.0121) \\
(-.0143) \\
(.0509)\end{array}$ & $\begin{array}{l}.0043 \\
.0041 \\
.0047\end{array}$ & $\begin{array}{l}(.2124) \\
(.1659) \\
(.1646)\end{array}$ \\
\hline $\begin{array}{l}\text { Missouri } \\
\quad \text { all [14] } \\
\text { no fp [9] } \\
\text { fp [5] }\end{array}$ & $\begin{array}{l}-0.1202 \\
-0.1292 \\
-0.1040\end{array}$ & $\begin{array}{l}-.0073 \\
-.0095 \\
-.0032\end{array}$ & $\begin{array}{l}(-.7214) \\
(-.7230) \\
(-.2643)\end{array}$ & $\begin{array}{l}-.0081 \\
-.0007 \\
-.0097\end{array}$ & $\begin{array}{l}(-.4183) \\
(-.2828) \\
(-.4185)\end{array}$ \\
\hline $\begin{array}{l}\text { Pennsylvania } \\
\text { all [53] } \\
\text { no fp \& opt-out [47] } \\
\text { no fp [38] } \\
\text { opt out [9] } \\
\text { fp [6] }\end{array}$ & $\begin{array}{l}-0.0300 \\
-0.0272 \\
-0.0224 \\
-0.0504 \\
-0.0599\end{array}$ & $\begin{array}{l}.0083 \\
.0080 \\
.0081 \\
.0086 \\
.0101\end{array}$ & $\begin{array}{r}(1.1545) \\
(1.0399) \\
(.9578) \\
(.5418) \\
(.7659)\end{array}$ & $\begin{array}{r}.0030 \\
.0024 \\
.0030 \\
-.0019 \\
.0072\end{array}$ & $\begin{array}{r}(.2183) \\
(.1631) \\
(.1866) \\
(-.0624) \\
(.2850)\end{array}$ \\
\hline
\end{tabular}

Late Announcement Dates:

\begin{tabular}{|c|c|c|c|c|c|}
\hline Portf. [size] & -10 to +60 & -1 to +1 & (t-statistic) & -5 to +5 & (t-statistic) \\
\hline $\begin{array}{l}\text { Connecticut } \\
\text { all [18] } \\
\text { no fp [12] } \\
\text { fp [6] }\end{array}$ & $\begin{array}{l}-0.0460 \\
-0.0352 \\
-0.0675\end{array}$ & $\begin{array}{l}-.0060 \\
-.0057 \\
-.0068\end{array}$ & $\begin{array}{l}(-.5929) \\
(-.4465) \\
(-.4858)\end{array}$ & $\begin{array}{r}-.0119 \\
-.0180 \\
.0003\end{array}$ & $\begin{array}{r}(-.6099) \\
(-.7409) \\
(.0110)\end{array}$ \\
\hline $\begin{array}{l}\text { Missouri } \\
\text { all [14] } \\
\text { no fp [9] } \\
\text { fp [5] }\end{array}$ & $\begin{array}{r}0.0380 \\
0.0744 \\
-0.0043\end{array}$ & $\begin{array}{l}-.0070 \\
-.0042 \\
-.0006\end{array}$ & $\begin{array}{l}(-.7259) \\
(-.3354) \\
(-.0532)\end{array}$ & $\begin{array}{r}.0081 \\
.0050 \\
-.0141\end{array}$ & $\begin{array}{r}(.4419) \\
(.2106) \\
(-.6771)\end{array}$ \\
\hline $\begin{array}{l}\text { Pennsylvania } \\
\text { all [53] } \\
\text { no fp \& opt-out [47] } \\
\text { no fp [38] } \\
\text { opt out [9] } \\
\text { fp [6] }\end{array}$ & $\begin{array}{l}-0.0636 \\
-0.0667 \\
-0.0713 \\
-0.0518 \\
-0.0547\end{array}$ & $\begin{array}{r}-.0027 \\
-.0043 \\
-.0030 \\
-.0011 \\
.0042\end{array}$ & $\begin{array}{r}(-.3786) \\
(-.5090) \\
(-.3612) \\
(-.0677) \\
(.3191)\end{array}$ & $\begin{array}{r}-.0011 \\
-.0013 \\
-.0126 \\
.0108 \\
.0006\end{array}$ & $\begin{array}{r}(-.0799) \\
(-.0892) \\
(-.7813) \\
(.3640) \\
(.0236)\end{array}$ \\
\hline
\end{tabular}

As reported in table four, over the period extending from ten days before the event date to sixty days after, all portfolios cumulated to a negative average residual, except for two of the Missouri portfolios, the aggregate portfolio and the portfolio of firms with no fair price provision, which cumulated to a positive average residual in the regression run on the senate approval event date. ${ }^{137}$

137 One could speculate concerning why the investors in firms subject to a control share acquisition statute appeared to be better off than those in firms subject to other variants. The statute may have been perceived as more effective in delaying or thwarting bids, and 
But in every case these cumulative average residuals were not statistically significant in either a three, ten, or twenty day window around the event, or over the sixty day period following the event. ${ }^{138}$ Moreover, when plotted over the seventy-one day interval, the cumulative average residuals did not reveal any nice pattern. In fact, as table four shows, in some instances the cumulative residual immediately around the event date was positive.

The results of the study are, therefore, largely disappointing. They do not enable one to push, even incrementally, the balance of the debate over the efficacy of the statutes to one side or the other. Although the insignificance of the negative residuals could be the result of the weakness of the power of the tests, it could also be a reflection of the assessment of investors that these three second generation takeover statutes do not have a harmful impact on firms.

One way to cope with concern about the desirability of takeover statutes from the shareholders' perspective is to shift the statutory presumption: for example, fair price legislation could have optingin rather than opting-out clauses. ${ }^{139}$ This mechanism would make

shareholders desired such an impact, or it may have been viewed as clearly unconstitutional and therefore without any effect on bids. But such speculation is foolish, as is attributing any meaning to the difference in direction of the cumulative average residuals across the statutes, for given the absence of statistical significance, one cannot conclude that a directional difference exists.

${ }^{158}$ I looked at the 60-day cumulative average residual because where the event date is the introduction date, the interval includes the enactment date and thus contains the resolution of uncertainty concerning passage, although it also necessarily includes noise. The cumulative residuals of tbe firms tbat opted out of Pennsylvania's statute were no different from those of the other firms, although we might have expected them to be strongly negative given management's subsequent decision. Opting out similarly had little impact on firms. Although the residuals at or just before this event are positive, as is the cumulative average residual for the three days centered on the event, over the longer 71 day interval of 10 days before and 60 days after, as well as over shorter windows of $2,3,10$, and 20 days, they cumulate to an insignificant negative amount. The cumulative average residuals of the event study of the firms opting out from the Pennsylvania statute were ( $t$-statistic in parentheses):

$\begin{array}{rrrr}\text { day }-10 & \text { to }+60 & -.0028 & \\ \text { day }-5 \text { to }+5 & -.0207 & (-.7164) \\ \text { day }-1 \text { to }+1 & .0085 & (.5645) \\ \text { day }-1 \text { to } & 0 & .0131 & (1.0659) \\ \text { day } 0 \text { to }+1 & -.0069 & (-.5564) \\ \text { day }-10 \text { to }+10 & -.0121 & (-.3034)\end{array}$

${ }^{130}$ Ronald Gilson has also advocated such an approach. See R. Gilson, The Law and Finance of Corporate Acquisitions 1078 (1986). Two of the 21 states with second generation 
it more difficult for management to undermine shareholders' preferences by lobbying state legislators inasmuch as the shareholders would still have to endorse the rule. This tactic is not new in corporate law. Familiar examples of statutes that vary across states according to whether they presume the existence of a right or require the right to be expressly acknowledged in a charter are cumulative voting and preemptive rights provisions.

A shift in presumption for fair price statutes could make it easier for corporation codes to mirror shareholder sentiment. This is because the costs to shareholders of opting in and opting out are not symmetrical. Large shareholders and institutions might be able to block the adoption of a charter amendment-the opt-in procedure-by voting against management's proposal, because in public corporations as many as twenty percent of the shares do not vote. Yet it might be prohibitively expensive for the same shareholders to have included in the proxy agenda, against management's wishes, a proposal to exclude the firm from a statute's coverage-the opt-out procedure-and in this case the presence of nonvoting shares will cut against the shareholder. ${ }^{140}$ Changing the presumption of coverage, however, would be a mixed blessing: it would eliminate the reduction in transaction costs, which is the benefit of having a statute, for those firms whose shareholders would approve a shark repellent provision. Before endorsing the opt-in approach, therefore, it is necessary to know the number of firms in each category so that the direction in which one wishes to err can be sensibly determined. ${ }^{141}$

\section{Conclusion}

On examining the politics that produced the second generation takeover statute in Connecticut, I found only corporations and

statutes have such a presumption, but in one the opt-in procedure is fulfilled by a provision in the corporate bylaws rather than by charter amendment. See Ga. Code Ann. $\S 14-2-$ 235(a) (Supp. 1986); Minn. Stat. Ann. § 302A.671 (West 1985 \& Supp. 1987) (switching from opt-out to opt-in regime).

${ }^{140}$ An additional problem is that in many states shareholders cannot propose charter amendments on their own. See, e.g., Del. Code Ann. tit. 8, § 242(b) (1983).

${ }^{141}$ An alternative approach that retains the transaction-cost-reducing benefit would be to maintain the opt-out procedure but to allow a simple majority or some lower percentage-rather than a supermajority—vote of shareholders to exempt the firm from a statute's coverage. 
their lobbying organizations involved in the statute's passage. I could not identify any other groups who supported the legislation or who even perceived it to be in their interest. I also could not locate any evidence that the politics behind similar statutes in other states differed dramatically from Connecticut's. The best explanation of the political dynamics is that legislators are reacting to the immediate pressure of a firm in a situation in which support for the bill entails no discernible political cost.

This led me to direct my attention to the shareholder-manager and shareholder-shareholder nexus, for these are the relationships implicated by the statutes' politics. The expedited enactment of Connecticut's takeover law does not provide much information concerning who within the firm is the beneficiary of the legislation. Accordingly, I examined the effects of the different variants of takeover statutes on shareholder decisions to tender. I found that a fair price provision may result in shareholders tendering less frequently than a control share acquisition statute or no statute at all, but more frequently than a redemption rights provision. Given the interaction between a shareholder's desire to receive a higher premium and the desire to receive bids in the first place, a fair price provision may be the most popular shark repellent amendment and statute because, unlike other devices, it provides balance between these two concerns.

But not all firms adopt fair price provisions. I therefore sought to explore when shareholders would voluntarily desire fair price protection, and what the dynamics of self-help decisions could suggest concerning the demand for statutes. In contrast to the nowstandard criticism of shark repellent charter provisions, a story can be developed based on differential information costs in which it is to the benefit of some, but not all, shareholders to adopt a fair price provision. This implies that only firms with specific ownership structures-in particular, low concentrations of stock ownership-will voluntarily adopt such provisions. Although the empirical evidence is ambiguous, even assuming this story is correct, it still does not provide a clear answer to the question of why a statute is necessary to codify the provisions. All that I can assert with confidence is that a statute impacts differentially on firms. For many firms to which they apply, these are surely transaction-costreducing laws. But there will be situations in which second generation statutes enable managers to act in ways that a majority of 
their shareholders would not approve, ${ }^{142}$ and firms fitting into this group may well be the impetus behind the enactment of legislation. Given the conventional goal of corporate law, in which firms are to be run in the shareholders' interest, this consequence of takeover statutes-that they can undermine the sovereignty of shareholder decisions-should be cause for serious concern.

One further conclusion we can draw from the politics in Connecticut is that the regulation of corporations at the state level is not an unmitigated good. States in which there are not many major corporations, particularly where there are few acquirers, are more susceptible to the pressure of a specific target firm and hence are more likely to pass takeover regulations, which may have as the object entrenching the firm's management. In Delaware, no one firm can have the influence on the state legislature that Aetna has in Connecticut because so many more firms are incorporated in Delaware. In addition, Delaware's clientele is far more varied than that of a smaller state, which may have no acquiring firms and only a few targets. It is instructive that Delaware has been slow to move in the area of takeover regulation and instead requires shareholder approval for what other states are now starting to mandate: firms can opt in to fair price and other forms of protection by amending their charters. Thus Delaware's regime relies more heavily on the revealed preferences of shareholders. In the takeover game, where managers' and shareholders' interests can often collide, such that managers may seek to exert influence on legislatures in ways detrimental to shareholders, we may well have the least to fear in Delaware.

Given the persistent support across the states for takeover regulation, a reasonable forecast is that if-or as-new statutes are struck down by courts, different and more creative variations will be devised. Moreover, regulation of takeovers will not end even if state action is held to be preempted by the Williams Act. Rather, the political forum will shift from the state legislatures to Congress. What precise course of action Congress will follow is impossible to predict. But when the corporations and business groups that demanded these laws at the state level concentrate their efforts on Congress, they may well succeed.

${ }^{142}$ I leave for subsequent work the important question concerning the use of majority rule when not all shareholders have the same interest. 


\section{APPENDIX}

This appendix presents the calculation of the expected values used to rollback through the decision trees in figures 1-8. For convenience, the definitions of variables and assumptions concerning the relationships between variables stated in the text, are reproduced below.

\section{Definitions}

\begin{tabular}{|c|c|c|}
\hline $\mathrm{X}_{1}$ & $=$ & price per share of first-tier tender offer \\
\hline $\mathrm{X}_{2}$ & $=$ & price per share in second-tier merger \\
\hline $\mathrm{M}_{2}$ & $=$ & market price per share after a successful bid \\
\hline $\mathrm{M}_{1}$ & $=$ & $\begin{array}{l}\text { market price per share if the bid fails and there is } \\
\text { no subsequent bid }\end{array}$ \\
\hline $\mathbf{X}_{3}$ & $=$ & price offered by a competing bidder if the bid fails \\
\hline p & $=$ & the probability the tender offer succeeds \\
\hline $\mathbf{a}$ & $=$ & $\begin{array}{l}\text { the probability that the tender offer fails and } \\
\text { there is no second bid }\end{array}$ \\
\hline $2 a$ & $=$ & $\begin{array}{l}\text { the probability that the tender offer fails and } \\
\text { there is a second bid }\end{array}$ \\
\hline$q$ & $=$ & $\begin{array}{l}\text { the probability the merger is approved when there } \\
\text { is a fair price provision }\end{array}$ \\
\hline $\mathbf{r}$ & $=$ & $\begin{array}{l}\text { the probability that the merger is rejected when } \\
\text { there is a fair price provision and the bidder takes } \\
\text { no further action }\end{array}$ \\
\hline $\mathbf{S}$ & $=$ & $\begin{array}{l}\text { the probability that the merger is rejected when } \\
\text { there is a fair price provision and the bidder pays } \\
\text { the required price, } \mathrm{X}_{1} \text {, to complete the transaction }\end{array}$ \\
\hline h & $=$ & $\begin{array}{l}\text { the probability an appraisal court will value a dis- } \\
\text { senter's shares at } \mathrm{M}_{2}\end{array}$ \\
\hline$(1-h)$ & $=$ & $\begin{array}{l}\text { the probability an appraisal court will value a dis- } \\
\text { senter's shares at } \mathrm{X}_{1}\end{array}$ \\
\hline $\mathbf{n}$ & $=$ & $\begin{array}{l}\text { of the amount by which the probability of the } \\
\text { merger's rejection is increased when a shareholder } \\
\text { votes no to the merger and the vote matters, the } \\
\text { proportion that goes to increasing } r \text {. }\end{array}$ \\
\hline
\end{tabular}

Note: for several calculations the definition of a probability is used, in particular, that $s+r+q=1$. 
Assumptions.

$$
\begin{aligned}
& \text { (0-a) } \mathrm{M}_{2}<\mathrm{X}_{2}<\mathrm{X}_{1} \\
& \text { (0-b) } \mathrm{M}_{1}<\mathrm{X}_{1}<\mathrm{X}_{3} \\
& \text { (1) } \mathrm{M}_{2}=.59 \mathrm{X}_{1} \\
& \text { (2) } \mathrm{X}_{2}=.86 \mathrm{X}_{1} \\
& \text { (3) } \mathrm{M}_{1}=.61 \mathrm{X}_{1} \\
& \text { (4) } \mathrm{X}_{3}=1.17 \mathrm{X}_{1}
\end{aligned}
$$

A. Decision with no shark repellent provision (figure 1).

1. Decision at node 2:

(a) $h=1$ (no exercise of appraisal rights)

$$
\mathrm{X}_{2}>\mathrm{M}_{2} \quad(0-\mathrm{a})
$$

Decision rule: vote yes

(b) $0 \leq \mathrm{h} \leq 1$

$$
\begin{aligned}
& \mathrm{X}_{2} \gtreqless \mathrm{hM}_{2}+(1-\mathrm{h}) \mathrm{X}_{1} \\
& .86 \mathrm{X}_{1} \gtreqless \mathrm{h}\left(.59 \mathrm{X}_{1}\right)+(1-\mathrm{h}) \mathrm{X}_{1} \quad(1,2) \\
& \mathrm{h} \gtreqless .34 \\
& \text { Decision rule: } \mathrm{h}>.34 \text {, vote yes } \\
& \mathrm{h}<.34 \text {, vote no }
\end{aligned}
$$

2. Decision at node 1 :

(a) $\mathrm{h}>.34$ (vote yes)

$$
\begin{aligned}
& (\mathrm{p}+2 \mathrm{a}) \mathrm{X}_{1}+\mathrm{aM}_{1} \gtreqless \mathrm{pX}_{2}+\mathrm{aM}_{1}+2 \mathrm{XX}_{3} \\
& (\mathrm{p}+2 \mathrm{a}) \mathrm{X}_{1} \gtreqless .86 \mathrm{pX} \mathrm{X}_{1}+1.17(2 \mathrm{a}) \mathrm{X}_{1} \quad(2,3,4) \\
& .14 \mathrm{p} \mathrm{Decision}^{.34 \mathrm{a}} \text { rule: } \mathrm{p}>.34 \mathrm{a} / .14 \text {, tender shares }
\end{aligned}
$$

Note: Because $a=(1-p) / 3$, this decision rule reduces to tender if $\mathrm{p}>.447$.

(b) $\mathrm{h}<.34$ (vote no)

$$
\begin{aligned}
& (\mathrm{p}+2 \mathrm{a}) \mathrm{X}_{1}+\mathrm{aM}_{1} \gtreqless \mathrm{phM}_{2}+\mathrm{p}(1-\mathrm{h}) \mathrm{X}_{1}+\mathrm{aM}_{1}+2 \mathrm{aX} \\
& \mathrm{pX}_{1} \gtreqless .59 \mathrm{phX} 1+\mathrm{p}(1-\mathrm{h}) \mathrm{X}_{1}+.34 \mathrm{aX} \\
& \mathrm{p} \gtreqless .34 \mathrm{a}+.59 \mathrm{ph}-\mathrm{ph}+\mathrm{p} \\
& .41 \mathrm{ph} \gtreqless .34 \mathrm{a} \\
& \text { Decision rule: } \mathrm{ph}>.83 \mathrm{a} \text {, tender shares }
\end{aligned}
$$

Note: Rearranging terms, we consider $\mathrm{p} \gtreqless .34 \mathrm{a} / .41 \mathrm{~h}$. The denominator will be less than the denominator in A.1.(a), so p must be greater than a larger number when the shareholder would vote no to get him to tender. 
3. Decision recognizing blended premium:

If bid and merger are successful the tendering shareholder receives per share: $.5 \mathrm{X}_{1}+.5 \mathrm{X}_{2}=.93 \mathrm{X}_{1}$ (2)

(a) $\mathrm{h}>.34$ (vote yes)

$$
\begin{aligned}
& (\mathrm{p}+2 \mathrm{a})(.5) \mathrm{X}_{1}+\mathrm{aM} \mathrm{M}_{1}+\mathrm{p}(.5) \mathrm{X}_{2} \gtreqless \mathrm{pX}_{2}+\mathrm{aM}_{1}+2 \mathrm{aX}_{3} \\
& a+.93 p \gtreqless 2.34 \mathrm{a}+.86 \mathrm{p} \\
& .07 \mathrm{p} \gtreqless 1.34 \mathrm{a} \\
& \mathrm{p} \gtreqless .86 \\
& \text { Decision rule: } \mathrm{p}>.86 \text {, tender shares } \\
& \text { (b) } \mathrm{h}<.34 \text { (vote no) } \\
& (\mathrm{p}+2 \mathrm{a})(.5) \mathrm{X}_{1}+.5\left\{\mathrm{phM}_{2}+\mathrm{p}(1-\mathrm{h}) \mathrm{X}_{1}\right\}+\mathrm{aM}_{1} \\
& \gtreqless \mathrm{phM}_{2}+\mathrm{p}(1-\mathrm{h}) \mathrm{X}_{1}+\mathrm{aM}_{1}+2 \mathrm{aX}_{3} \\
& .5 \mathrm{p}+\mathrm{a} .5 \mathrm{ph}(.59)+.5 \mathrm{p}(1-\mathrm{h})+2.34 \mathrm{a} \\
& .205 \mathrm{ph} \gtreqless 1.34 \mathrm{a} \\
& \text { ph } 1.34 \mathrm{a} / .205 \\
& \text { Decision rule: } \mathrm{ph}>1.34 \mathrm{a} / .205 \text {, tender }
\end{aligned}
$$

Note: in both of these blended premium cases, the cutoff for tendering is higher than the cutoff when the blending is not recognized.

B. Decision when there is a fair price rule (figure 2).

1. Decision at node 2:

$$
\begin{aligned}
& \mathrm{qX}_{2}+\mathrm{rM}_{2}+\mathrm{sX} \mathrm{X}_{1} \gtreqless \mathrm{q}\left\{\mathrm{hM}_{2}+(1-\mathrm{h}) \mathrm{X}_{1}\right\}+\mathrm{rM}_{2}+\mathrm{sX} \\
& .86 \gtreqless .59 \mathrm{~h}+1-\mathrm{h}(1,2) \\
& .41 \mathrm{~h} \gtreqless .14 \\
& \text { Decision rule: } \mathrm{h}>.34 \text {, vote yes } \\
& \mathrm{h}<.34 \text {, vote no }
\end{aligned}
$$

Note: this decision is unchanged from the decision with no shark repellent amendment.

2. Decision at node 1 :

(a) $\mathrm{h}>.34$ (vote yes)

$$
\begin{aligned}
& (\mathrm{p}+2 \mathrm{a}) \mathrm{X}_{1}+\mathrm{aM}_{1} \gtreqless \mathrm{p}\left\{\mathrm{qX}_{2}+\mathrm{rM}_{2}+\mathrm{sX} \mathrm{X}_{1}\right\}+\mathrm{aM}_{1}+ \\
& \quad 2 \mathrm{aX} \mathrm{s} \\
& \mathrm{p}+2 \mathrm{a} \sum_{2.34 \mathrm{a}}+\mathrm{p}(.86 \mathrm{q}+.59 \mathrm{r}+\mathrm{s}) \quad(1,2) \\
& \mathrm{p} \gtreqless .34 \mathrm{a} /(1-.86 \mathrm{q}-.59 \mathrm{r}-\mathrm{s}) \\
& \text { Decision rule: } \mathrm{p}>.34 \mathrm{a} /(1-.86 \mathrm{q}-.59 \mathrm{r}-\mathrm{s}), \text { tender }
\end{aligned}
$$

Note: If $1-.86 \mathrm{q}-.59 \mathrm{r}-\mathrm{s}=.14$, or substituting, $\mathrm{q}+2.9 \mathrm{r}=1$, then a fair price rule has no effect on decision to tender. Rearranging 
and substituting terms, if $1.9 \mathrm{r}<\mathrm{s}$, $(\mathrm{r}<.53 \mathrm{~s})$, the shareholder tenders less frequently with a fair price rule.

(b) $\mathrm{h}<.34$ (vote no)

$$
\begin{array}{rl}
(\mathrm{p}+2 \mathrm{a}) \mathrm{X}_{1} & +\mathrm{aM}_{1} \gtreqless \mathrm{p}\left\{\mathrm{rM}_{2}+\mathrm{sX}_{1}+\mathrm{qhM}_{2}+\mathrm{q}(1-\mathrm{h}) \mathrm{X}_{1}\right\}+ \\
\mathrm{aM}_{1} & +2 \mathrm{aX} \\
\mathrm{p} & \mathrm{aX}_{3} .34 \mathrm{a} /(1-.59 \mathrm{r}-\mathrm{s}-\mathrm{q}+.41 \mathrm{qh}) \\
\mathrm{p} & .34 \mathrm{a} /(.41 \mathrm{r}+.41 \mathrm{qh}) \text { (substitution) } \\
\text { Decision rule: } \mathrm{p}>.34 \mathrm{a} /(1-.59 \mathrm{r}-\mathrm{s}-\mathrm{q}+.41 \mathrm{qh}), \text { tender }
\end{array}
$$

Note: If $r /(1-q)=h$, then a fair price rule has no effect on decision to tender. Rearranging and substituting terms, if $r<\mathrm{sh} /$ (1-h), the shareholder tenders less frequently with a fair price rule.

3. Decision where vote affects merger outcome (figure 3).

Here we assume if the shareholder votes no, $q=0$, and if he votes yes $q=1$. For technical convenience, for the outcomes when the vote is no, I write the probability of receiving $M_{2}$ as $r+n q$ and of receiving $X_{1}$ as $s+(1-n) q$.

(a) Decision at node 2:

$$
\begin{aligned}
& \mathrm{X}_{2} \gtreqless(\mathrm{r}+\mathrm{nq}) \mathrm{M}_{2}+\{\mathrm{s}+(1-\mathrm{n}) \mathrm{q}\} \mathrm{X}_{1} \\
& .86 \gtreqless .59 \mathrm{r}+.59 \mathrm{nq}+\mathrm{s}+\mathrm{q}-\mathrm{nq} \\
& .27 \gtreqless .41 \mathrm{~s}+.41 \mathrm{q}-.41 \mathrm{nq} \\
& \mathrm{nq} \gtreqless .34-\mathrm{r} \\
& \text { Decision rule: } \mathrm{nq}>.34-\mathrm{r} \text {, vote yes } \\
& \mathrm{nq}<.34-\mathrm{r} \text {, vote no }
\end{aligned}
$$

(b) Decision at node 1:

1. $\mathrm{nq}>$.34-r (vote yes)

We note that this is the same tree as decision A.2.(a) (figure 1), and we have the same rule as with no provision.

$$
\begin{aligned}
& \text { 2. nq }<.34-\mathrm{r} \text { (vote no) } \\
& (\mathrm{p}+2 \mathrm{a}) \mathrm{X}_{1}+\mathrm{aM}_{1} \gtreqless \mathrm{p}(\mathrm{r}+\mathrm{nq}) \mathrm{M}_{2}+\mathrm{p}\{\mathrm{s}+(1-\mathrm{n}) \mathrm{q}\} \mathrm{X}_{1}+ \\
& \mathrm{aM}_{1}+2 \mathrm{aX}_{3} \\
& \mathrm{p} \geqq .34 \mathrm{a}+\mathrm{ps}+\mathrm{pq}-\mathrm{pnq}+.59 \mathrm{pr}+.59 \mathrm{pnq} \\
& \mathrm{p} 3.34 \mathrm{a}+\mathrm{p}(.59 \mathrm{r}+\mathrm{s}+\mathrm{q}-.41 \mathrm{nq}) \\
& \mathrm{p} \gtreqless .34 \mathrm{a} /(1-\mathrm{s}-\mathrm{q}-.59 \mathrm{r}+.41 \mathrm{nq}) \\
& \text { Decision rule: } \mathrm{p}>.34 \mathrm{a} /(.41 \mathrm{r}+.41 \mathrm{nq}) \text {, tender }
\end{aligned}
$$

Note: There will be no effect on the decision with the rule if $\mathrm{r}+\mathrm{nq}=\mathrm{h}$. 
C. Decision with truncated tree, only node 2 .

1. If no fair price rule, compare:

$$
\mathrm{X}_{2} \gtreqless \mathrm{hM}_{2}+(1-\mathrm{h}) \mathrm{X}_{1}
$$

2. If fair price rule, compare:

$$
\mathrm{qX}_{2}+\mathrm{rM}_{2}+\mathrm{sX_{1 }} \gtreqless \mathrm{qhM}_{2}+\mathrm{q}(1-\mathrm{h}) \mathrm{X}_{1}+\mathrm{rM}_{2}+\mathrm{sX_{1 }}
$$

Compare results with and without rule:

(a) vote yes

$$
\begin{aligned}
& \mathrm{X}_{2} \mathrm{qX}_{2}+\mathrm{rM}_{2}+\mathrm{sX}_{1} \\
& .86 \gtreqless .86 \mathrm{q}+\mathrm{s}+.59 \mathrm{r} \\
& -.14 \gtreqless-.14 \mathrm{q}-.41 \mathrm{r}
\end{aligned}
$$

Note: If $.14 q+.41 \mathrm{r}>.14$, the expected value is greater with a fair price rule.

(b) vote no

$$
\begin{aligned}
& \mathrm{hM}_{2}+(1-\mathrm{h}) \mathrm{X}_{1} \gtreqless \mathrm{qhM}_{2}+\mathrm{q}(1-\mathrm{h}) \mathrm{X}_{1}+\mathrm{rM}_{2}+\mathrm{sX} \\
& .59 \mathrm{~h}+1-\mathrm{h} \gtreqless .59 \mathrm{qh}+\mathrm{q}-\mathrm{qh}+.59 \mathrm{r}+\mathrm{s} \\
& -.41 \mathrm{~h} \gtreqless-.41 \mathrm{r}-.41 \mathrm{qh} \\
& \mathrm{r} \mathrm{h}(1-\mathrm{q}) \\
& \mathrm{h} \gtreqless \mathrm{r} /(1-\mathrm{q})
\end{aligned}
$$

Note: The expected value with a fair price rule is greater when $r /(1-q)>h$.

D. Decision when there is a supermajority provision (figure 5).

1. Decision at node 2:

$$
\begin{aligned}
& \mathrm{qX}_{2}+(1-\mathrm{q}) \mathrm{M}_{2} \gtreqless \mathrm{hM}_{2}+(1-\mathrm{h}) \mathrm{X}_{1} \\
& .86 \mathrm{q}+.59(1-\mathrm{q}) \gtreqless .59 \mathrm{~h}+1-\mathrm{h} \\
& .27 \mathrm{q} \gtreqless .41-.41 \mathrm{~h} \\
& \mathrm{~h} \gtreqless 1-.65 \mathrm{q}=\mathrm{r}+\mathrm{s}+.35 \mathrm{q}
\end{aligned}
$$

Decision rule: $h>1-.65 q$, vote yes

$$
\mathrm{h}<1-.65 \mathrm{q} \text {, vote no }
$$

2. Decision at node 1 :

(a) $\mathrm{h}>1-.65 \mathrm{q}$ (vote yes)

$$
\begin{aligned}
& (p+2 a) X_{1}+a M_{1} \sum p q X_{2}+p(1-q) M_{2}+a M_{1}+2 a X_{3} \\
& \mathrm{p} \gtreqless .34 \mathrm{a}+.86 \mathrm{pq}+.59 \mathrm{p}-.59 \mathrm{pq} \\
& .41 \mathrm{p} \gtreqless .34 \mathrm{a}+.27 \mathrm{pq} \\
& \text { Decision rule: } \mathrm{p}>.34 \mathrm{a} /(.41-.27 q) \text {, tender }
\end{aligned}
$$

Note: This cutoff value for $p$ is smaller than the cutoff value when there is a fair price provision. To see this we compare:

$.41-.27 q$ to $1-.86 q-.59 r-s$. 
Substituting and rearranging terms this simplifies to

$.59 \mathrm{r}+.59 \mathrm{q}+\mathrm{s} \gtreqless .59$, or $1.6 \mathrm{~s}>\mathrm{s}$.

If $.41-.27 q<.14$, the cutoff value for $p$ will be smaller with a supermajority provision than the cutoff value with no shark repellent provision.

(b) $\mathrm{h}<1-.65 \mathrm{q}$ (vote no)

We note that this decision problem is the same as the tree in figure 1 with no shark repellent amendment and we get the same decision rule as in A.2.(b), tender if .41ph $>.34$ a.

3. Decision if vote affects merger outcome (figure 4):

(a) Decision at node 2:

$$
\mathrm{X}_{2}>\mathrm{M}_{2}
$$

Decision rule: always vote yes

(b) Decision at node 1 :

$$
(\mathrm{p}+2 \mathrm{a}) \mathrm{X}_{1}+\mathrm{aM}_{1} \gtreqless \mathrm{pX}_{2}+\mathrm{aM}_{1}+2 \mathrm{aX}
$$

We note that this decision is the same as the decision in A.2.(a), voting yes with no shark repellent amendment, and we get the same rule, tender if $.14 p>.34 a$.

E. Decision when there is a redemption rights rule (figure 6).

1. Decision at node 2:

$$
\mathrm{X}_{1}>\mathrm{hM}_{2}+(1-\mathrm{h}) \mathrm{X}_{1}
$$

Decision rule: always exercise redemption rights against bidder

2. Decision at node 1:

$$
\begin{aligned}
& (\mathrm{p}+2 \mathrm{a}) \mathrm{X}_{1}+\mathrm{aM}_{1} \gtreqless \mathrm{pX}_{1}+\mathrm{aM}_{1}+2 \mathrm{aX} \\
& \mathrm{p}+2 \mathrm{a} \gtreqless \mathrm{p}+2.34 \mathrm{a} \\
& \mathrm{p}<\mathrm{p}+.34 \mathrm{a}
\end{aligned}
$$

Decision rule: always do not tender

Note: In figure 6a, the two-step acquisition with a redemption rights provision, the decision at node 3 is always exercise redemption rights against the bidder rather than go to court, and because $\mathrm{X}_{2}<\mathrm{X}_{1}$, the decision at node 2 is always vote no to the second step acquisition in order to exercise the redemption right. Because $(\mathrm{p}+2 \mathrm{a}) \mathrm{X}_{1}+\mathrm{aM_{1 }}<\mathrm{pX}_{1}+\mathrm{aM}_{1}+2 \mathrm{aX} \mathrm{X}_{3}$, as before, the decision rule is always do not tender. 
F. Decision when there is a control share acquisition rule (figures 7-8).

1. Decision when vote has no affect on outcome:

(a) No appraisal rights (figure 7a):

$$
\mathrm{pX}_{1}+\mathrm{aM}_{1}+2 \mathrm{aX}_{3} \gtreqless \mathrm{pM}_{2}+\mathrm{aM}_{1}+2 \mathrm{aX}_{3}
$$

Decision rule: always vote yes

(b) Appraisal rights (figure 7):

$$
\begin{aligned}
& \mathrm{pX}+\mathrm{aM}_{1}+2 \mathrm{aX}_{3} \\
& \mathrm{p} \sum \mathrm{phM}_{2}+\mathrm{p}(1-\mathrm{h}) \mathrm{X}_{1}+\mathrm{aM}_{1}+2 \mathrm{aX}_{3} \\
& 0>-.41 \mathrm{ph}
\end{aligned}
$$

Decision rule: always vote yes

Note: In figure $7 \mathrm{~b}$, the two step acquisition with a control share acquisition rule with appraisal rights, the shareholder always votes no at node 2 because,

$$
\begin{aligned}
& \mathrm{qX}_{2}+(1-\mathrm{q}) \mathrm{M}_{2} \gtreqless \mathrm{hM}_{2}+(1-\mathrm{h}) \mathrm{X}_{1} \\
& .86 \mathrm{q}+.59(1-\mathrm{q}) \gtreqless .59 \mathrm{~h}+(1-\mathrm{h}) \\
& .41 \mathrm{~h} \gtreqless .41+.14 \mathrm{q} \\
& \mathrm{h}<1+.34 \mathrm{q} .
\end{aligned}
$$

But he always votes yes at node 1 because $X_{1}>h M_{2}+(1-h) X_{1}$. If there are no appraisal rights, the end result is still the same; although the shareholder now votes yes at node 2 because $\mathrm{qX}_{2}+(1-\mathrm{q}) \mathrm{M}_{2}>\mathrm{M}_{2}$, he still always votes yes at node 1 because $\mathrm{X}_{1}>\mathrm{qX}_{2}+(1-\mathrm{q}) \mathrm{M}_{2}$.

\section{Decision when vote affects outcome (figure 8):}

If the vote is yes, $p=1$. Here we assume that if the vote is no, $p=0$, and the change in probability is distributed between the two results of a bid's failure, receiving $\mathrm{X}_{3}$ or $\mathrm{M}_{1}$. For technical convenience I first allocate the increased probability proportionately, adding $2 \mathrm{p} / 3$ and $1 \mathrm{p} / 3$ respectively. I then relax this assumption and add $n p$ and $(1-n) p$ respectively to those outcomes.

(a) proportional adjustment in probabilities:

$$
\mathrm{X}_{1} \gtreqless(\mathrm{a}+\mathrm{p} / 3) \mathrm{M}_{1}+(2 \mathrm{a}+2 \mathrm{p} / 3) \mathrm{X}_{3}
$$

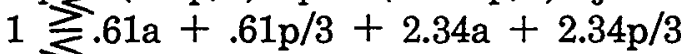

$1 \gtreqless 2.95 \mathrm{a}+2.95 \mathrm{p} / 3$

$.338 \gtreqless a+p / 3$

$.338>.333$ (substitution)

Decision rule: always vote yes

(b) general adjustment in probabilities:

$$
\mathrm{X}_{1} \gtreqless(\mathrm{a}+\mathrm{np}) \mathrm{M}_{1}+\{2 \mathrm{a}+\mathrm{p}(1-\mathrm{n})\} \mathrm{X}_{3}
$$




$$
\begin{aligned}
& 1 \gtreqless .61 \mathrm{a}+.61 \mathrm{np}+2.34 \mathrm{a}+1.17 \mathrm{p}-1.17 \mathrm{np} \\
& .05 \mathrm{a} \gtreqless .17 \mathrm{p}-.56 \mathrm{np} \quad \text { (substitution) } \\
& \mathrm{p} \gtreqless-.0166 /(.56 \mathrm{n}-.1866) \text { (substitution) } \\
& \text { Decision rule: } \mathrm{p}>-. .0166 /(.56 n-.1866) \text {, vote yes }
\end{aligned}
$$

Note: If $\mathrm{n}>.333$, this reduces to $\mathrm{p}>0$, and the rule is always vote yes.

G. Decisions if appraisal court awards $\mathrm{X}_{3}$ with probability (1-h) rather than $\mathrm{X}_{1}$.

1. No shark repellent provision:

(a) Decision at node 2:

$$
\begin{aligned}
& \mathrm{X}_{2} \mathrm{hM}_{2}+(1-\mathrm{h}) \mathrm{X}_{3} \\
& .86 \mathrm{~s}^{2}+1.17(1-\mathrm{h}) \\
& \mathrm{h} .53 \\
& \text { Decision rule: } \mathrm{h}>.53, \text { vote yes } \\
& \mathrm{h}<.53, \text { vote no }
\end{aligned}
$$

Note: The shareholder votes no more frequently than before because $.53>.34$.

(b) Decision at node $1, \mathrm{~h}<.53$, vote no:

$$
\begin{aligned}
& (p+2 a) X_{1}+a M_{1} \gtreqless p h M_{2}+p(1-h) X_{3}+a M_{1}+2 a X_{3} \\
& p+2 a j 2.34 a+.59 p h+1.17 p-1.17 p h \\
& .58 p h \gtreqless .34 a+.17 p \\
& p h \gtreqless(.34 a+.17 p) / .58 \\
& \text { Decision rule: } p h>(.34 a+.17 p) / .58, \text { tender }
\end{aligned}
$$

Note: When $(.34 a+.17 p) / .58>.34 a / .41$, the shareholder tenders less frequently when the maximum appraisal value is $X_{3}$ than when it is $\mathrm{X}_{1}$. When they are equal, the decision is unaffected.

2. Fair price rule:

(a) Decision at node 2:

Same as G.1(a)

(b) Decision at node $1, \mathrm{~h}<.53$ (vote no):

$$
\begin{gathered}
(\mathrm{p}+2 \mathrm{a}) \mathrm{X}_{1}+\mathrm{aM}_{1} \gtreqless \mathrm{p}\left\{\mathrm{qhM}_{2}+(1-\mathrm{h}) \mathrm{qX} \mathrm{X}_{3}+\mathrm{rM}_{2}+\mathrm{sX}\right\}+ \\
a \mathrm{M}_{1}+2 \mathrm{aX} \\
2 \mathrm{a}+\mathrm{p} \gtreqless 2.34 \mathrm{a}+\mathrm{p}(.59 \mathrm{qh}+1.17 \mathrm{q}-1.17 \mathrm{qh}+.59 \mathrm{r}+\mathrm{s}) \\
\mathrm{p} \gtreqless .34 \mathrm{a} /(1-.59 \mathrm{r}-1.17 \mathrm{q}-\mathrm{s}+.58 \mathrm{qh}) \\
\text { Decision rule: } \mathrm{p}>.34 \mathrm{a} /(1-.59 \mathrm{r}-1.17 \mathrm{q}-\mathrm{s}+.58 \mathrm{qh}) \\
\text { tender }
\end{gathered}
$$


Note: The possibility of receiving the higher appraisal value has no effect on the decision to tender if $h=1$. Since $h>1$ is not possible, the shareholder tenders less frequently when the court may award $\mathrm{X}_{3}$ instead of $\mathrm{X}_{1}$.

3. Fair price rule, decision affects merger outcome:

Note: Changing the maximum received in appraisal does not affect this decision because if the shareholder votes no the merger does not succeed and there will be no appraisal proceeding.

4. Supermajority rule:

(a) Decision at node 2:

$$
\begin{aligned}
& \mathrm{qX}_{2}+(1-\mathrm{q}) \mathrm{M}_{2} \gtreqless \mathrm{hM}_{2}+(1-\mathrm{h}) \mathrm{X}_{3} \\
& .86 \mathrm{q}+.59-.59 \mathrm{q} \gtreqless .59 \mathrm{~h}+1.17-1.17 \mathrm{~h} \\
& .27 \mathrm{q}+.58 \mathrm{~h} \gtreqless .58 \\
& \mathrm{~h} \gtreqless 1-.46 \mathrm{q} \\
& \text { Decision rule: } \mathrm{h}>1-.46 \mathrm{q} \text {, vote yes } \\
& \mathrm{h}<1-.46 \mathrm{q}, \text { vote no }
\end{aligned}
$$

Note: The shareholder votes no more frequently than before because 1-.46q $>1-.65 q$. The shareholder votes no more frequently than he does under a fair price provision when $1-.46 q>.53$, that is, when $.98>q$.

(b) Decision at node $1, \mathrm{~h}<1-.46 \mathrm{q}$ (vote no):

$$
(\mathrm{p}+2 \mathrm{a}) \mathrm{X}_{1}+\mathrm{aM}_{1} \gtreqless \mathrm{phM}_{2}+\mathrm{p}(1-\mathrm{h}) \mathrm{X}_{3}+\mathrm{aM}_{1}+2 \mathrm{aX}
$$

Note: This decision problem is the same as G.1.

5. Supermajority rule, decision affects merger outcome:

Same as G.3.

6. Redemption rights rule:

$\mathrm{X}_{1} \gtreqless \mathrm{hM}_{2}+(1-\mathrm{h}) \mathrm{X}_{3}$

$1 \gtreqless .59 h+1.17(1-h)$

$.58 \mathrm{~h} \gtreqless .17$

$\mathrm{h} \gtreqless .29$

Decision rule: $h>.29$, exercise redemption rights

$\mathrm{h}<.29$, go to appraisal court

Note: The shareholder still always does not tender because $(2 \mathrm{a}+\mathrm{p}) \mathrm{X}_{1}+\mathrm{aM}_{1}<\mathrm{p}\left\{\mathrm{hM}_{2}+(1-\mathrm{h}) \mathrm{X}_{3}\right\}+\mathrm{aM}_{1}+2 \mathrm{aX}$ and 
$(2 \mathrm{a}+\mathrm{p}) \mathrm{X}_{1}+\mathrm{aM}_{1}<\mathrm{pX}_{1}+\mathrm{aM}_{1}+2 \mathrm{aX}_{3}$.

7. Control share acquisition rule:

$\mathrm{pX}_{1}+\mathrm{aM}_{1}+2 \mathrm{aX}_{3} \gtreqless \mathrm{phM}_{2}+\mathrm{pX}_{3}-\mathrm{phX}_{3}+\mathrm{aM}_{1}+2 \mathrm{aX}$

$1 \gtreqless .59 \mathrm{~h}+1.17-1.17 \mathrm{~h}$

$\mathrm{h} \gtreqless .29$

Decision rule: $\mathrm{h}>.29$, vote yes

$\mathrm{h}<.29$, vote no

Note: Now the shareholder does not always vote yes.

8. Control share acquisition rule, decision affects outcome: Same as G.3. 
HeinOnline -- 73 Va. L. Rev. 2001987 